Florida International University FIU Digital Commons

\title{
Turkish-American Relations in the Post-Cold War Era, 1990-2005
}

Isa Afacan

iafacan@gmail.com

DOI: $10.25148 /$ etd.FI1 1041509

Follow this and additional works at: https://digitalcommons.fiu.edu/etd

\section{Recommended Citation}

Afacan, Isa, "Turkish-American Relations in the Post-Cold War Era, 1990-2005" (2011). FIU Electronic Theses and Dissertations. 347. https://digitalcommons.fiu.edu/etd/347

This work is brought to you for free and open access by the University Graduate School at FIU Digital Commons. It has been accepted for inclusion in FIU Electronic Theses and Dissertations by an authorized administrator of FIU Digital Commons. For more information, please contact dcc@fiu.edu. 


\section{FLORIDA INTERNATIONAL UNIVERSITY}

Miami, Florida

TURKISH-AMERICAN RELATIONS IN THE POST-COLD WAR ERA, 1990-2005

A dissertation submitted in partial fulfillment of the

requirements for the degree of

DOCTOR OF PHILOSOPHY

in

INTERNATIONAL RELATIONS

by

Isa Afacan

2011 
To: Dean Kenneth Furton

College of Arts and Sciences

This dissertation, written by Isa Afacan, and entitled Turkish-American Relations in the post-Cold War Era, 1990-2005, having been approved in respect to style and intellectual content, is referred to you for judgment.

We have read this dissertation and recommend that it be approved.

Thomas Breslin

Aisha Musa

Charles MacDonald

Mohiaddin Mesbahi, Major Professor

Date of Defense: March 31, 2011

The dissertation of Isa Afacan is approved.

Dean Kenneth Furton

College of Arts and Sciences

Interim Dean Kevin O'Shea

University Graduate School

Florida International University, 2011 
(C) Copyright 2011 by Isa Afacan

All rights reserved. 


\section{DEDICATION}

I dedicate this dissertation to my wife, Esra. Without her patience, understanding, support, and most of all love, the completion of this work would not have been possible. 


\section{ACKNOWLEDGMENTS}

This dissertation benefitted from many individuals' contributions along the way. I would like to express my deep appreciation and gratitude to those who inspired and helped me through this long process. My major Professor, Mohiaddin Mesbahi, has been the prime scholar to lay out the intricacies of international relations and to give me the inspiration to write on Turkish-American relations. Professors on my committee, Charles MacDonald, Thomas Breslin and Aisha Musa, provided me their invaluable feedback and contributed greatly to my study. I would like thank all four for their time, patience and support.

This dissertation could not have been completed without support from the Jack D. Gordon Institute for Public Policy and Citizenship Studies and the Middle East Studies Center at Florida International University, both of which provided the graduate student research funding for this research. I would like to thank Paul Kowert, Luz Aviles and Martha Rodriguez from the Department of Politics and International Relations for their valuable support in helping me navigate university bureaucracy. I also thank my colleague Sarabrynn Hudgins for her assistance in editing the text under a tight schedule.

I would like to recognize and give utmost appreciation to my parents and my lateuncle, who offered unconditional love and support. Last, but not least, I would like to thank my wife, Esra. Without her patience, understanding, support, and, most of all, love, the completion of this work would not have been possible. 


\begin{abstract}
OF THE DISSERTATION
TURKISH-AMERICAN RELATIONS IN THE POST-COLD WAR ERA, 1990-2005

by
\end{abstract}

Isa Afacan

Florida International University, 2011

Miami, Florida

Professor Mohiaddin Mesbahi, Major Professor

This study examines the contours of Turkish-American foreign relations in the post-Cold War era from 1990 to 2005 . While providing an interpretive analysis, the study highlights elements of continuity and change and of convergence and divergence in the relationship between Ankara and Washington. Turkey's encounter with its Kurdish problem at home intertwined with the emergence of an autonomous Kurdish authority in northern Iraq after the Gulf War that left a political vacuum in the region. The main argument of this dissertation is that the Kurdish question has been the central element in shaping and redefining the nature and scope of Turkish-American relations since 1991. This study finds that systemic factors primarily prevail in the early years of the post-Cold War Turkish-American relations, as had been the case during the Cold War era. However, the Turkish parliament's rejection of the deployment of the U.S. troops in Turkey for the invasion of Iraq in 2003 could not be explained by the primacy of distribution of capabilities in the system. Instead, the role of identity, ideology, norms, and the socialization of agency through interaction and language must be considered. The Justice and Development Party's ascension to power in 2002 magnified a wider 
transformation in domestic and foreign politics and reflected changes in Turkey's own self-perception and the definition of its core interests towards the United States. 


\section{TABLE OF CONTENTS}

CHAPTER

PAGE

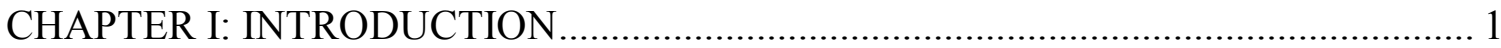

Statement of the Problem............................................................................. 1

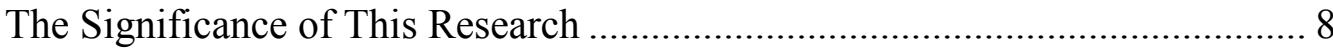

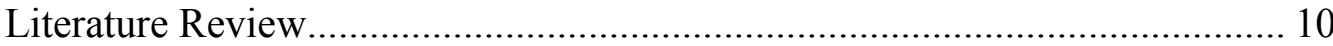

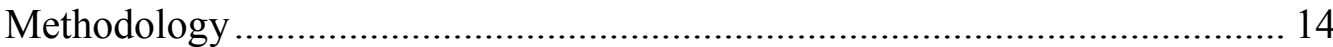

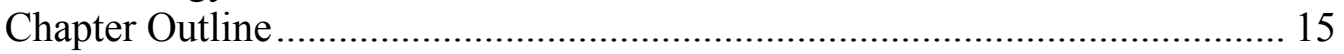

CHAPTER II: TURKISH-AMERICAN RELATIONS: AN HISTORICAL

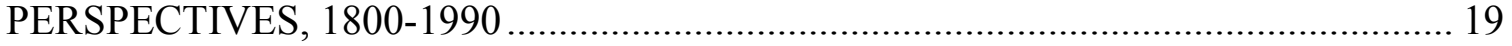

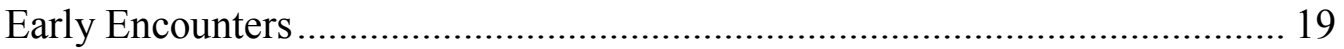

World War I, the Interwar Period and the Relations .................................... 22

World War II and the Cold War .................................................................. 28

Disappointments and Crises.......................................................................... 40

CHAPTER III: THE SHADOW OF THE GULF WAR AND THE KURDISH

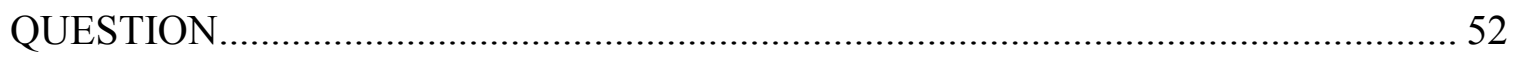

The Post-Cold War Security Thinking and Turkish Calculations ................... 53

The Gulf War and the U.S. Engagement in Iraqi Kurdistan........................... 56

Facing Twin Problems: The de facto Kurdish State in the Neighborhood

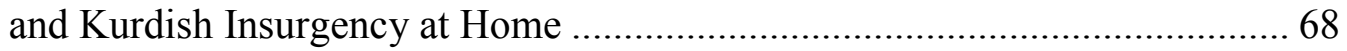

Implications of the Kurdish Problem for the Turkey-U.S. Relations .............. 81

CHAPTER IV: TOWARDS STRATEGIC PARTNERSHIP, $1994-2000$................... 84

Disappointments and Prospect for Engagement ......................................... 85

Turkey's Domestic and foreign affairs intricately mingled: Israel and the

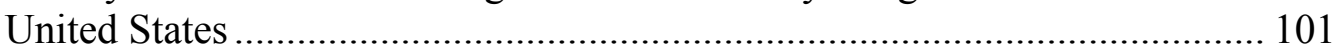

Gearing towards Strategic Partnership between Ankara and Washington ..... 110

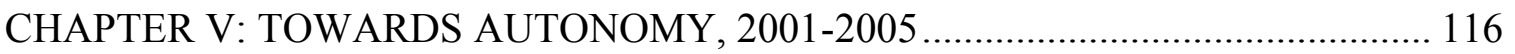

Allies Agreed and then Disagreed: The September 11 Attacks, and the

Polices of "War on Terror" and "Axis of Evil" ............................................. 120

Strategic Partnership in Jeopardy: Iraqi War of 2003 ................................ 126

The Contours of Turkey's Transformation in Domestic and Foreign Affairs. 132

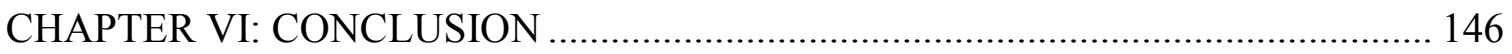

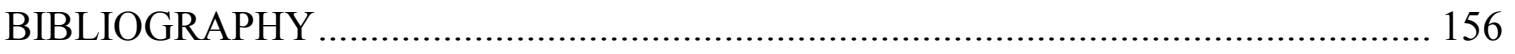

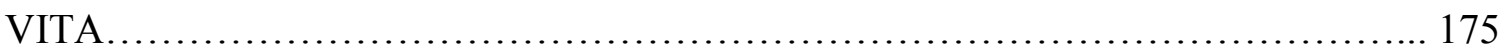




\section{LIST OF ABBREVIATIONS}

\begin{tabular}{|c|c|}
\hline DECA & Defense and Economic Cooperation Agreemen \\
\hline DLP & Democratic Left Party \\
\hline DP & Democrat Party \\
\hline EPR & European Recovery Program \\
\hline GAP & Guneydogu Anadolu Projesi \\
\hline GMEI & Greater Middle East Initiative \\
\hline IMF & International Monetary Fund \\
\hline ISRO & International Strategic Research Organization \\
\hline JDP & Justice and Development Party \\
\hline KDP & Kurdistan Democratic Party \\
\hline MP & Motherland Party \\
\hline NATO & North Atlantic Treaty Organization \\
\hline $\mathrm{NSC}$ & National Security Council \\
\hline $\mathrm{OPC}$ & Operation Provide Comfort \\
\hline PKK & Partiya Karkeren Kurdistan \\
\hline PLO & Palestinian Liberation Organization \\
\hline PUK & Patriotic Union of Kurdistan \\
\hline RPP & Republican People's Party \\
\hline SDPP & Social Democrat People's Party \\
\hline TGNA & Turkish Grand National Assembly \\
\hline TPP & True Path Party \\
\hline TRT & Turkish Radio and Television \\
\hline
\end{tabular}




$\begin{array}{ll}\text { TUSIAD } & \text { Turk Sanayicileri ve Isadamlari Dernegi } \\ \text { UN } & \text { United Nations } \\ \text { UNSC } & \text { United Nations Security Council } \\ \text { VP } & \text { Virtue Party } \\ \text { WB } & \text { World Bank } \\ \text { WP } & \text { Welfare Party }\end{array}$




\section{CHAPTER I: INTRODUCTION}

\section{Statement of the Problem}

Since the beginning of the Cold War, the Turkish-American relationship has been very important for both sides. Turkish security during the Cold War was mostly shaped by its location as a neighbor of the Soviet Union. Turkey was identified as a "bufferzone" or "bulwark" against Soviet expansion. Soviet territorial demands on Turkey in 1945, along with the threat of communism, compelled Turkey to seek western support for its own defense. The United States (U.S.) Congress passed an historic legislation, known as the Truman Doctrine, as part of the containment strategy that entailed helping smaller nations resist Soviet expansionism. The passage of the Truman doctrine was a major milestone for Turkish-American relations, given that it was designed to help Turkey and Greece militarily counter Soviet expansionism in the region. As part of its containment strategy, the United States sought to strengthen France, Great Britain and Germany economically, and create a strong and unified Europe by including other nations to counter Soviet power. Providing monetary aid to European countries, including Turkey and Greece, through the International Monetary Fund (IMF) and the World Bank (WB) would help revive their economies, adjust macroeconomic stability, and eventually provide market opportunities for American goods. ${ }^{1}$ What was officially dubbed as the European Recovery Program (EPR) but widely known as the Marshall Plan provided necessary economic backing to Turkey, which was suffering economic turmoil at the time. Turkey's integration into the western economic and security systems concluded

\footnotetext{
${ }^{1}$ See Turkaya Ataov, Amerika, Nato Ve Turkiye (Ankara: Ileri Yayinlari, 1969).; Huseyin Bagci, Turk Dıs Politikasinda 1950'li Ylllar (Ankara: METU Press, 2001).; Namik Behramoglu, Türkiye Amerikan Ilişkileri: Demokrat Parti Dönemi (Yar Yayinlari, 1973).
} 
when Turkey joined the North Atlantic Treaty Organization (NATO) as a founding member in 1952 . Thereafter, Turkish foreign and security policies were mostly pegged into the United States' interests, so much so, in fact, that the partnership was perceived to be constant in an otherwise ever-changing international environment that emerged from the bipolar nature of the era. It does not mean that the relationship did not have its ups and downs. One has only to recall the Johnson letter of 1964 or the U.S. embargo on arms sales to Turkey because of the Turkish intervention of Cyprus in 1974. However, the dissolution of the Soviet Union, which was the prime actor in initiating the Cold War, changed the very nature of the international system and brought new dynamics to the relationship between Turkey and the United States. ${ }^{2}$

My dissertation thus examines the nature of Turkish-American foreign relations in the post-Cold War era from 1990 to 2005. The primary purpose of this dissertation is to illustrate the historical evolution of Turkish-American foreign relations in the post-Cold War era by shedding light on major developments such as the Gulf War, the emergence of an autonomous Kurdish authority in northern Iraq, the September $11^{\text {th }}$ attacks, and the rising activism of Turkish foreign policy in the Middle East and the Iraqi War of 2003. I argue that these developments played significant roles in shaping the nature of relationship between the two countries in this new era.

The post-Cold War environment left Turkey soul-searching as it needed to situate itself in an era of uncharted territory, deviating from the relative predictability of the Cold War international system. Old threats of Soviet expansionism were no longer present.

\footnotetext{
${ }^{2}$ See discussions on the subject, Idris Bal, 21. Yüzyılda Türk Dış Politikası (Ankara: Global Arastirmalar Merkezi, 2006).; Haydar Cakmak, Turk Dis Politikası, 1919-2008 (Ankara: Platin, 2008).; Kamran İnan, Dis Politika (Ankara: Otuken Nesriyat, 1993).; Baskın Oran and Atay Akdevelioğlu, Turk Dis Politikasi: KurtuluşS Savaşından Bugune Olgular, Belgeler, Yorumlar (Iletisim Yayinlari, 2004).
} 
Instead, new and non-traditional security threats surfaced, such as the rise of ethnic separatism and radical Islamism, proliferation of weapons of mass destruction and instability in Turkey's immediate neighborhood. ${ }^{3}$ My dissertation primarily deals with the question of how and to what extent Turkey managed and shaped its relations with the United States in this tumultuous period. To refine and explain overarching themes and processes, this dissertation takes the "Kurdish question" as one of the prime driving forces in defining Turkey's relations with the U.S. in the post-Cold War era, especially in the aftermath of the Gulf War. Turkey's encounter with its Kurdish problem at home intertwined with the emergence of an autonomous Kurdish authority in northern Iraq after the Gulf War that left a political vacuum in the region. This dissertation also intends to answer the question of how and to what extent the interplay of domestic and international issues on the Kurdish question defined the nature of Turkey's relations with the United States.

The secondary purpose of the present study is to shed light on a framework that explains how and to what extent the Turkish-American relationship has been driven by agencies' (Turkish and American) preferences or structural factors. When one looks at the nature of Turkey's relations with the United States during the Cold War, and its aftermath in 1990s, it can be argued that structural factors mostly determined the nature of the Turkish-American relations. However, Ankara's refusal on March 1, 2003 to base

\footnotetext{
${ }^{3}$ See Hakan Yavuz, Secularism and Muslim Democracy in Turkey (Cambridge University Press, 2009).; Graham E. Fuller, The New Turkish Republic: Turkey as a Pivotal State in the Muslim World (Washington, DC: United States Institute of Peace Press, 2008).; Stephen Larabee Angel Rabasa, The Rise of Political Islam in Turkey (Santa Monica, CA: RAND, 2008).; Emin Fuat Keyman, Remaking Turkey: Globalization, Alternative Modernities, and Democracy (Lanham, MD: Lexington Books, 2007).; Kemal Kirişci, "Turkey's Foreign Policy in Turbulent Times," in Chaillot Paper (Paris: Institute for Security Studies, 2006).; Bernard M. Hoekman Sübidey Togan, Turkey: Economic Reform and Accession to the European Union (Washington, DC: World Bank, 2005).; Omer Taspinar, Kurdish Nationalism and Political Islam in Turkey: Kemalist Identity in Transition (New York: Routledge, 2005).
} 
62,000 American troops on Turkish soil, and a more assertive Turkish foreign policy in the Middle East, crystallized doubts regarding the stability of long-heralded TurkishAmerican relations. Both Turkish and American policymakers had good cause for concern. The conflict over Iraq and the threat of downsizing the Incirlik Air Base, as well as the detention of Turkish soldiers in Northern Iraq by American troops in early July 2004, put the strategic partnership in jeopardy. ${ }^{4}$ These events indicated that the strategic partnership had not been able to withstand changes in the international system. Against this backdrop, it is important to determine whether the downward spiral of relations over the past few years was the result of structural/systemic reasons or resulted from agencies' redefinition of identity or of ideology.

By the term "structure," I mean the Waltzian understanding of the international structure of international relations. As Kenneth Waltz argues, "international structure emerges from the interaction of states and then constrains them from taking certain actions while propelling them towards others." ${ }^{5}$ Anarchy and the absence of central institutions (a world government) characterize the structure of the system. In this framework, individual states are units/agents that interact in the system. They act according to the principle of self-help and seek to ensure their own survival. The relationship between agents and structure is limited to the constraints that structure places on agents through competition. ${ }^{6}$ Thus, according to structural realism, as Waltz claims,

\footnotetext{
${ }^{4}$ Philip H. Gordon and Omer Taspinar, Winning Turkey: How America, Europe, and Turkey Can Revive a Fading Partnership (Washington, DC: Brookings Institution Press, 2008).

${ }^{5}$ Kenneth Waltz, "Realist Thought and Neorealist Theory," Journal of International Affairs 44, no. 1 (1990).

${ }^{6}$ Kenneth Neal Waltz, Theory of International Politics (Reading, MA: Addison-Wesley, 1979).
} 
states do not differ in the tasks they execute but in their capabilities. Capabilities define the position of states in the system and the distribution of capabilities defines the structure of the system. Similarly, changes in the distribution of capabilities stimulate changes in the structure of the system, as from a bipolar to a unipolar power configuration, or from a bipolar to a multipolar one.

By assuming that states are functionally similar, Waltz ignores identity, ideology, norms and preferences of agency as variables. He also disregards socialization of agents through dynamic interactions that might shape or re-shape one's identity and therefore its interests. States, according to Waltz, seek the same goals. Having made the case for limiting agency to only powerful states, Waltz recognizes that power is a vital attribute of agency. On the other hand, constructivists ${ }^{7}$ concern themselves with the identity, and ideational and political preferences of agency, and its implications for international structure. For example, Alexander Wendt is convinced that agents act according to interests that are the consequence of identity, which is socially constructed. It is a product of the normative structures that are in place and the process of interaction in which the agent participates, namely international relations. Identities are contextual and so are

\footnotetext{
${ }^{7}$ They range from Nicholas G. Onuf, Friedrich V. Kratochwil, Emauel Adler, Jeffrey Checkel, Martha Finnemore, to Alexander Wendt. See Nicholas Greenwood Onuf, World of Our Making : Rules and Rule in Social Theory and International Relations (Columbia, S.C.: University of South Carolina Press, 1989).; Nicholas Onuf, "Constructivism: A User's Manual," in International Relations in a Constructed World, ed. Nicholas Onuf Vendulka Kubalkova, and Paul Kowert (New York: M. E. Sharpe, 1998).; V. Kubálková, Nicholas Greenwood Onuf, and Paul Kowert, International Relations in a Constructed World (Armonk, N.Y.: M.E. Sharpe, 1998).; Alexander E. Wendt, "Anarchy Is What States Make of It: The Social Construction of Power Politics," International Organization 46, no. 2 (1992).; Alexander Wendt, Social Theory of International Politics, Cambridge Studies in International Relations (New York: Cambridge University Press, 1999).; Emanuel Adler, "Seizing the Middle Ground: Constructivism in World Politics," European Journal of International Relations 3, no. 3 (1997).; Jeffrey Checkel, "International Norms and Domestic Politics: Bridging the Rationalist-Constructivist Divide," European Journal of International Relations 3, no. 4 (1997).
} 
interests. States, according to Wendt, are social actors whose identities and interests are endogenously constructed. ${ }^{8}$

Given the discussion of the agent-structure problematique in International Relations above, Turkish-American relations in the post-Cold War era, especially the events that unfolded during the Iraqi War of 2003, might be perfect grounds for testing of these theoretical premises. While the Turkish involvement in the Gulf War in 1990 on the side of the United States might fit well with the arguments of the Waltzian understanding of international structure, however, the Turkish parliament's rejection of the deployment of the U.S. troops in Turkey for the invasion of Iraq in 2003 cannot be explained by the primacy of distribution of capabilities in the system. Instead, the role of identity, ideology, and norms, and the socialization of agency through interaction and language, should be employed. Hence, it is very important to determine how and to what extent agency and structure of international system interplay in this particular relationship and shape one another.

I argue that systemic factors primarily prevailed in the early years of the postCold War Turkish-American relations, as had been the case during the Cold War era. The rise of the United States as the sole superpower after the collapse of its rival, the Soviet Union, is the key to defining the nature of Turkish-American relations. As Gideon Rose argues, "the relative material power resources countries possess will shape the magnitude and ambition ... of their foreign policies: as their relative power rises states will seek more influence abroad, and as it falls their actions and ambitions will be scaled back

\footnotetext{
${ }^{8}$ See Wendt, "Anarchy Is What States Make of It: The Social Construction of Power Politics."
} 
accordingly." ${ }^{9}$ Growing U.S. interests in the greater Middle East also coincided with Turkish interests as Turkey tried to liberalize its economic and political system and hoped to gain more influence in newly-independent states in the Caucasus and Central Asia. However, this does not mean that the role of agency does not count. For example, the rise of nationalism and political Islam among Turkish voters during the 1990s, in part, challenged the U.S. involvement in the region and showed the role of agency's new identity formation. As many constructivists argue, identities are constructed through narratives and language that eventually shape interests. As language and interaction of agents, in part, determine policies, identity takes a life of its own. As Ole Waever dubbed it is a "speech act." Labeling a problem as belonging to the realm of security legitimize the use of extraordinary measures by the state. ${ }^{10}$ By bringing both material and ideational elements into the picture, one can see how dynamic interaction of these elements shapes and redefines one's identity and interests.

To see how these played out in Turkish-American relations, I considered the following questions: What was the underlying reasoning for Turkey to support the United States during the Gulf War? How did the Turkish leaders perceive the involvement and the presence of the U.S. in the Middle East in general and in Iraq in particular? How and to what extent did the "Kurdish Question" especially the rise of Partiya Kerkeran Kurdistan (PKK) terrorism and the emergency of an autonomous Kurdish entity in

\footnotetext{
${ }^{9}$ Gideon Rose, "Neoclassical Realism and Theories of Foreign Policy," World Politics 51, no. 1 (1998)., p. 151. The argument that interests expand with power was also introduced in Paul Kennedy, The Rise and Fall of the Great Powers: Economic Change and Military Conflict from 1500-2000 (New York: Random House, 1987).

${ }^{10}$ Ole Waever Barry Buzan, Jaap de Wilde, Security: A New Framework for Analysis (Boulder, CO: Lynne Rienner Publishers, 1998).
} 
northern Iraq affect the nature of Turkish-American relations? Did Turkish foreign policy's orientation experience a convergence or divergence in its interests because of the U.S. engagement in the region? If so, what are the implications? Additionally, how and to what extent did the U.S. policies of "war on terror" and the "axis of evil" rhetoric in the aftermath of the September 11 attacks shape Turkey's perception of the United States? Why did the Iraqi War of 2003 strain the relationship and what were the long-term effects on their relations?

Occasionally, suspicions were voiced that Turkey had hopes to play an enhanced role in the Middle East, independent from, and, in fact, as an alternative to, the U.S. initiatives. However, Turkey has not yet come close to being a "regional leader" or a "role model" in the Caucasus and Central Asia, a prospect the U.S. supported strongly throughout the 1990s. ${ }^{11}$ Whether Turkey has an ambitious design for a regional role or a foreign policy that is "drifting" without an anchor or direction is one of the points that will be covered by this study. However, the aforementioned questions will be answered in a context whereby the evolution of Turkish-U.S. relations from 1990 to 2005 is properly addressed. To put it differently, the main concern is the fact that all those questions raised can be better understood by looking at the historical evolution of postCold War Turkish-American relations.

\section{The Significance of This Research}

The necessity to focus on this topic is dictated by four main reasons: first, it is worth examining why Turkey's foreign policy, at one time status quo-oriented and

\footnotetext{
${ }^{11}$ Andrew Mango, "The Turkish Model," Middle Eastern Studies 29, no. 4 (1993).; Heinz Kramer, A Changing Turkey: The Challenge to Europe and the United States (Washington, D.C.: Brookings Institution Press, 2000).
} 
comfortable with the United States, became hesitant, cautious and skeptical toward the U.S. after the Gulf War. There are many studies conducted on the Gulf War and its implications but there is no comprehensive study that focuses on the primacy of the Kurdish question in determining the nature of Turkey's relations with the United States in the post-Cold War world. Second, there has been an upsurge in theoretical discussions about the agent-structure debate in the last two decades. This study will contribute to emerging literature on the subject, and serve as a testing ground of agent-structure debate particularly on Turkey's decision on stationing of American soldiers on Turkish soil prior to the war in 2003 . Third, there is a need to address the changing regional as well as global environment after the Gulf War, September 11 attacks and the U.S. invasion of Iraq. These events heavily impacted the very nature of Turkish-U.S. relations. However, they can be meaningful by looking at patterns of relations between two countries in the post-Cold War era with a flashback on the continuity and change in the history of engagement between two countries for more than two centuries. Fourth, there is a critical gap in the scholarship on Turkish-U.S. relations in the post-Cold War era. Although there is considerable amount of commentary and analysis on different aspects of Turkish-U.S. relations in popular media, think tank publications and to the lesser extent in academia, by pundits, policy community and scholars, there is unfortunately no single comprehensive study (books, monographs or a dissertation) devoted to this specific subject. There are some chapters in edited books, or journal articles touching some aspects of this topic, but there is no scholarly book surveying Turkey-U.S. relations in the post-Cold War era. My dissertation will, I think, provide a historically grounded, theoretically relevant and refreshing study of the topic. 


\section{Literature Review}

There has been a surge of research on Turkey, specifically on its relations with the European Union. ${ }^{12}$ This increase can be attributed to Turkey's prospect of accession to the European Union in the late 1990s and early 2000s. In Turkey, more scholars are working on the EU accession process than in any other areas in the discipline of political science. It is quite easy to understand that both the subject matter and the available funding made possible more research on Turkey's relations with the European Union. On the other hand, studies on Turkish-American relations have been limited to a small number of foreign policy practitioners, journalists and some academics. For example, former U.S. ambassador to Turkey Morton Abramowitz wrote books on the subject matter such as Turkey's Transformation and American Policy. ${ }^{13}$ A renowned Turkish journalist, Cengiz Candar penned scholarly articles ${ }^{14}$ in respected journals and columns in Turkish newspapers. Abramowitz's book, Turkey's Transformation and American Policy, covers numerous issues including changing Turkish domestic politics, Turkey's

\footnotetext{
${ }^{12}$ See, Meltem Müftüler-Bac, Turkey's Relations with a Changing Europe (New York: Manchester University Press, 1997).; Yannis A. Stivachtis Meltem Müftüler-Baç, Turkey-European Union Relations: Dilemmas, Opportunities, and Constraints (Lanham, MD: Lexington Books, 2008).; Sübidey Togan, Turkey: Economic Reform and Accession to the European Union.; Burak Akçapar, Turkey's New European Era: Foreign Policy on the Road to Eu Membership (Lanham, MD: Rowman \& Littlefield Publishers, 2006).; Knud Erik Jørgensen Esra LaGro, Turkey and the European Union: Prospects for a Difficult Encounter (Palgrave Macmillan, 2007).; Erik Jan Zürcher, The European Union, Turkey and Islam (Amsterdam: Amsterdam University Press, 2004).; Mehmet Özcan Sedat Laçiner, İhsan Bal, European Union with Turkey: The Possible Impact of Turkey's Membership on the European Union (Ankara: Usak, 2005).; Harun Arikan, Turkey and the Eu: An Awkward Candidate for Eu Membership? (Burlington, VT: Ashgate, 2006).; Constantine Arvanitopoulos, Turkey's Accession to the European Union: An Unusual Candidacy, ed. Constantine Arvanitopoulos (Springer, 2009).

${ }^{13}$ Morton Abramowitz, Turkey's Transformation and American Policy, ed. Morton Abramowitz (New York: Century Foundation Press, 2000).

${ }^{14}$ Cengiz Çandar, "Turkey's "Soft Power" Strategy: A New Vision for a Multi-Polar World," (Ankara: SETA, 2009).; Graham Fuller Cengiz Candar, "Grand Geopolitics for a New Turkey," Mediterranean Quarterly 12, no. 1 (Winter 2001).; Cengiz Çandar, "The Kurdish Question: The Reasons and Fortunes of the 'Opening'," Insight Turkey 11, no. 4 (2009).
} 
Kurdish issue, Turkish perception of the U.S. policies, and American policies towards Turkey. Even though the main theme is Turkish-American relations, Abramowitz emphasizes the complexities of the subject matter and lays out intricate connections between domestic and foreign issues in a scholarly way. Even though he covered a wide array of topics, he was somewhat disconnected with continuity and change dynamics, and could not present a fuller picture of the relationship. Similar problems also appear in Allies Divided: Transatlantic Policies for the Greater Middle East ${ }^{15}$ edited by Robert D. Blackwill and Michael Sturmer. Interestingly enough, all contributing authors were from western European nations, with no scholars of Middle Eastern descent included. To a certain degree, the book lacks the complexity that only a more intimate and regionally sensitive scholarship can provide. It is a somewhat dry account of the relations. Without adequate knowledge of primary resources a reader would not capture the fuller picture.

Heinz Kramer, in his competently written book, A Changing Turkey: The Challenges to Europe and the United States ${ }^{16}$ assesses changing dynamics from the erosion of Kemalist tradition, the rise of political Islam, the shifting impact of military on politics, the growing influence of the Kurdish question on Turkish politics to foreign policy implications with regard to Central Asia, the Balkans, the European Union, and the United States. His main argument posits that shifting domestic dynamics deeply influence Turkey's foreign policy choices. He also argues that, once hyped, Turkey's weight in the newly independent Turkic nations in Central Asia is no longer applicable because of its mistakes and the constraints of Turkish political and economic instability in the mid-

\footnotetext{
${ }^{15}$ Michael Stürmer Robert D. Blackwill, Allies Divided: Transatlantic Policies for the Greater Middle East (Cambridge, MA: MIT Press, 1997).

${ }^{16}$ Kramer, A Changing Turkey: The Challenge to Europe and the United States.
} 
1990s. Therefore, he argues that the U.S. was not successful in working with Turkey on reaching out to Central Asian nations.

An important work published in Turkish is Turkiye-ABD Iliskilerinin Politikasi ${ }^{17}$ (The Politics of Turkish-American Relations) that was written by Burcu Bostanoglu. She argued that there is an apparent "theoretical poverty" in examining Turkey's foreign policy. Therefore, she intended not to write a diplomatic history of the Turkish-American relations but to plan a study of the topic with a markedly different perspective that was not available in Turkish by utilizing theoretical discussions on national interests, foreign policy analysis, and contending theories of international relations. Even though her endeavor is new in Turkish-language books on the subject, it is difficult to comprehend the Turkish translation of theoretical concepts. One can only wish that she could have published the text in the English language so as to spark more discussions and research.

Apart from studies solely focusing on Turkey's relations with the West, particularly the United States, one book should be noted for its contribution to the analysis of Turkish foreign policy. Turkish Foreign Policy, 1774-2000, was written by a leading scholar on Turkish politics and foreign policy, William Hale. ${ }^{18}$ This book is a classic, well-rounded history of Turkish foreign policy that spanned more than two centuries. In Hale's book, one could see the dynamics of continuity and change and could identify multi-faceted aspects of Turkish foreign policy. It has become a reference book that many scholars cite in their works. Philip Robins in his Suits and Uniforms: Turkish

\footnotetext{
${ }^{17}$ Burcu Bostanoglu, Turkiye-Abd Iliskilerinin Politikasi, 2 ed. (Ankara: Imge Kitabevi Yayinlari, 2008).

${ }^{18}$ William M. Hale, Turkish Foreign Policy, 1774-2000 (London ; Portland, OR: Frank Cass, 2000).
} 
Foreign Policy since the Cold War ${ }^{19}$ defines the Turkish foreign policy as status quooriented. According to Robins, the Turkish political elite venerated "the sanctity of borders, of states, of multilateral institutions and of norms of conduct, even when it became clear that systemic changes had rendered some of these continuities no longer tenable. ${ }^{20} \mathrm{He}$ also posits that Turkish foreign policy is aligned westward by being a part of NATO and aspiring to join the European Union. Even though he does a good job of laying out parameters and the evolution of Turkish foreign policy, his work nonetheless lacked the intricate analysis of non-Kemalist segments in Turkish society, especially that of observant Muslims and Kurds, and their increasing impact on foreign policy-making as shaped by their election of center-right and conservative parties to the Turkish government. To a certain degree, they were one of the driving forces in Turkey's activist foreign policy as it tilted towards an independent foreign policy orientation.

My dissertation also brings discussions from journalists such as Cengiz Candar from Yenisafak, Yasemin Congar from Milliyet, Sami Kohen from Milliyet, Ali H. Arslan from Zaman, Fehmi Koru from Yeni Safak, and Mehmet A. Birand from Posta. These individuals write and talk about Turkish-U.S. relations as events unfold, and they are also considered to be opinion-makers in areas of Turkish foreign policy. However, what is more pressing is that most of the studies mentioned here have a significant flaw: either they lack the intimacy of primary resources or they are written from a more "local viewpoint" that lacks major secondary resources and perspectives. Therefore, my

\footnotetext{
${ }^{19}$ Philip Robins, Suits and Uniforms: Turkish Foreign Policy since the Cold War (Seattle, Wash.: University of Washington Press, 2003).

${ }^{20}$ Ibid, p. 6
} 
dissertation attempts to bridge the gap and focus on both primary and secondary resources authoritatively.

Methodology

My dissertation aims at giving an interpretive analysis of the U.S.-Turkish relationship from 1990 to 2005 . My study attempts to provide an analysis of the nature of the relationship by giving relevant historical background to show the elements of continuity and change. As indicated earlier, both primary and secondary resources will be utilized. To reflect upon the nature of Turkish reactions on major events such as the Iraqi War of 2003, views and news from major Turkish newspapers such as Milliyet, Hurriyet, Sabah and Zaman will be considered. In the summer of 2008, I went to Turkey to do a field research. The Jack D. Gordon Institute for Public Policy and Citizenship Studies and the Middle East Studies Center at Florida International University provided research funding for this research. I conducted research in Istanbul and Ankara for five weeks. Spending considerable time at the Milli Kutuphane (the National Library) in Ankara, I primarily went through books, monographs, newspapers, government documents, research reports and other relevant materials that have been written in Turkish. Especially, going through seven newspapers with diverse editorial perspectives (Milliyet, Hurriyet, Sabah, Cumhuriyet, Radikal, Yenisafak and Zaman), covering the period from 1989 to 2005, took most of my time in Ankara. The next venue included the library of Bilkent University. This library provided a vast collection of the secondary resources as the Milli Kutuphane did in the areas of primary sources. Additionally, I visited the Ministry of Foreign Affairs in Ankara and utilized the special library of the Stratejik Arastirmalar Merkezi, (the Center for Strategic Research) a research arm of the ministry. 
The last part of the research in Ankara included research and discussions at a think tank the Siyaset, Ekonomi ve Toplum Arastirmalari Vakfi (the Foundation for Political, Economic and Social Research). I gained access to reports, policy briefs and other research papers, and attended extensive discussions on the role of Turkey in the Middle East, the transformation of Turkish foreign policy, and U.S.-Turkey relations. The second leg of the research took place in Istanbul. Visiting the libraries at Bogazici University complemented my research especially in the areas of the historical evolution of U.S.Turkey relations, which will be covered in Chapter 2. The library of historic Istanbul University was the next stop and largely offered resources published in the Turkish language. The last part of the research in Istanbul was conducted at the Islam Arastirmalari Merkezi (the Center for Islam Studies). The research continued in the United States especially in the libraries of Florida International University, Emory University, Georgia State University, Georgia Institute of Technology, the University of Chicago and the University of Southern California.

\section{Chapter Outline}

My dissertation is thematically driven and consists of introduction, conclusion and four chapters in between. Chapter II surveys the Turkish-American relationship from 1800 to 1990 . The reason behind the inclusion of this historical narrative that spans almost two centuries is to elaborate on dynamic elements of continuity and change in the relations. Chapter II starts with early encounters between the U.S. and the Ottoman Empire. It lays out series of events that played significant roles in shaping foreign policy objectives on both sides: President Wilson's fourteenth point dealing with the issue of self-determination for minorities under the decaying Ottoman rule, the situation of 
American missionary schools both under the Ottomans and young Turkish republic, the inter-war era politics (1919-1939), the ramifications of the Cold War on foreign policy and divergent views on the issue of Cyprus and opium production. Chapter II basically builds up a historical background and points of reference for the discussion for following chapters.

Chapter III addresses the emergence of a new partnership between Turkey and the United States during the first Gulf War (1990-1991) as both Ankara and Washington tried to adjust to the realities of the post-Cold War world. With the demise of the Soviet Union and the reorientation of Western geostrategic priorities, the future of TurkishWestern relations in general and Turkish-American relations in particular was uncertain during the early 1990s. Turkey was perceived as an awkward partner with whom "nobody wanted to be dragged into various local conflicts which could easily increase in the new political climate." ${ }^{21}$ Many in Turkey feared that the new strategic landscape would exclude Turkey from the emerging security institutions in Europe, thus lessening its importance to Washington. Turkish President Turgut Ozal's support for the Gulf War coalition brought these fears to an end, solidifying Turkey's renewed role in emerging western security and political structures. However, the salience of the Kurdish question at home and the emergence of the "de facto Kurdish state",2 in northern Iraq after the Gulf War brought a significant cloud to Ankara's relations with Washington. The chapter tries to dissect the triangular relations with the U.S., Turkey and Kurdish factions in Iraq, and its implications for larger issues in the region.

${ }^{21}$ Hale, Turkish Foreign Policy, 1774-2000,, p. 288

${ }^{22}$ See Michael M. Gunter, "A De Facto Kurdish State in Northern Iraq," Third World Quarterly 14, no. 2 (1993). 
Chapter IV deals with nature of the post-Gulf war relationship between Turkey and the U.S. after 1994 and explores how the relationship was elevated to a level of "strategic partnership" by 1999. The U.S. interests in securing the Persian Gulf, countering the rise of Islamism and stabilizing the Balkans, Central Asia and the Caucasus necessitated the continuation of military cooperation and close strategic relations with Turkey. To deepen the partnership, Prime Minister Mesut Yilmaz and President Clinton agreed on a five-part agenda that would push the expansion of bilateral cooperation. Dubbed the "strategic partnership," the agenda identified energy, economic issues, security cooperation, and regional cooperation as areas necessitating enhanced collaboration. While Turkey was seeking the relaxation of U.S. import duties on Turkish goods, and favored more trade opportunities, the U.S. viewed economic ties as a means of securing the Turkey's westward orientation, improving its European accession prospects and encouraging democratic reforms.

Chapter V examines the question of how and to what extent the September $11^{\text {th }}$ terrorist attacks and the Iraqi War of 2003 impacted Turkish-American relations. The September $11^{\text {th }}$ attacks redefined the nature of the U.S. interests in the "Greater Middle East." Initially, the "war on terror" reinforced traditional American and Turkish strategic ties. However, President George W. Bush identified two of Turkey's neighbors (Iran and Iraq) as parts of "axis of evil." The identification of the axis and American emphasis on Syria as a "rogue state" brought new challenges to Turkey. As the Bush administration began to expand its war on terrorism into Iraq, the nature of Turkish-American relations dramatically shifted. Over $90 \%$ of the Turkish public opposed the U.S. invasion of Iraq and the Turkish populace pressured the Turkish government not to host American troops 
on Turkish soil to start the invasion of Iraq from the north. Both international and structural factors pushed Turkey to side with the U.S. for the invasion. The Turkish Grand National Assembly, however, rejected a resolution that would authorize the stationing of American troops on Turkish soils for the invasion. Chapter V surveys series of events and perspectives and tries to analyze the role of agency in forming Turkey's identity and interests in a dynamic fashion. 


\section{CHAPTER II: TURKISH-AMERICAN RELATIONS: AN HISTORICAL}

PERSPECTIVES, 1800-1990

Starting with the end of the Second World War, Turkey's relations with the United States have been based on a strategic calculation that the imminent Soviet threat in its neighborhood made Turkey seek a close alliance with the United States. A relationship that once was considered geographically distant and geopolitically less significant became paramount to both sides. However, this does not mean that previous encounters between the U.S. and the Ottoman Empire, and its successor, the Republic of Turkey $^{23}$, were not important. In fact, the two nations' encounters over centuries laid the groundwork for present-day engagement. Therefore, elaborating on the relations between the two nations will help explain the intricacies of the complex history behind TurkishAmerican relations in later periods.

\section{Early Encounters}

Relations between the Ottoman Turks and the United States started in the late $18^{\text {th }}$ century with the arrival of the first U.S. commercial ship in 1797 in Izmir, and of the frigate "George Washington" in Istanbul on November 11, $1800 .{ }^{24}$ In 1830 , the Sublime Porte $^{25}$ and Washington signed the "Treaty of Navigation and Trade." The treaty became

\footnotetext{
${ }^{23}$ The author uses Turkey and the Republic of Turkey interchangeably in this dissertation.

24 Bostanoglu, Turkiye-Abd Iliskilerinin Politikasi., p. 353. See also Fahir Armaoglu, Belgelerle TurkAmerikan Munasebetleri (Ankara: Turk Tarih Kurumu, 1991).; Tahsin Fendoglu, Osmanll-Amerika Ilişkileri, 1786-1929 (Beyan, 2002).

${ }^{25}$ French translation of "Bab-i Ali," literally means "High Gate." The term means in diplomatic circles "the government of the Ottoman Empire" as foreign ambassadors were received by the Ottoman sultans at the porte (gate) in the open court of Topkapi Palace in Istanbul.
} 
the main document for bilateral relations for almost a century. ${ }^{26}$ One of the treaty's significant articles called for extraterritorial rights for American merchants and missionaries who settled in the Ottoman lands. Another article included "most-favored nation" rights for the U.S., as was the case for major Western nations such as Great Britain, France and Germany. ${ }^{27}$ After signing the treaty, diplomatic and consular relations were established. Commodore David Porter was appointed as Chargé d'Affaires in Istanbul in 1831 and he received the title of Ambassador in 1839. However, permanent Ottoman consular representation in Washington was not possible until 1867. A second treaty was signed in 1862 to eliminate some of the differences that emerged over the decades and to further develop the relations between the Sublime Porte and Washington.

This new treaty included,

[F]ollowing provisions: (1) the Turkish government accorded most-favored-nation treatment to American citizens and ships; (2) permits to trade were not to be required of Americans; (3) the Turkish government agreed to charge equal import duties in respect to all nations; (4) the eight per cent ad valorem export duty then in force was to be reduced one per cent annually to a permanent level of one per cent; (5) an import duty of eight per cent ad valorem was to be levied upon all goods, with a provision for refund if re-exported within six months; (6) a provision for the single payment of duties was inserted to avoid repetition of experiences with corrupt Turkish customs officers; (7) Americans were guaranteed equality of treatment with regard to warehousing, bounties, drawbacks, and port facilities; (8) goods shipped in either American or Ottoman vessels were to have equality of treatment; (9) there was to be no transit charge for passage through the Dardanelles or the Bosphorus; (10) the old land transit duty of three per cent was reduced to one per cent; (11) the importation of arms and ammunition into Turkey was prohibited; and (12) a tariff commission was appointed to draw up a schedule of values upon which to base ad valorem duties. $^{28}$

As many American merchants and members of the diplomatic corps increased their involvement in the Ottoman domains, another powerful group of people began

\footnotetext{
${ }^{26}$ One secret clause in the treaty was that Ottoman government would purchase war ships from the U.S. but the U.S. Senate rejected the clause.

${ }^{27}$ Leland J. Gordon, "Turkish-American Treaty Relations," American Political Science Review 22, no. 3 (1928)., p. 712

${ }^{28}$ Ibid, p. 712
} 
settling there and establishing their institutions: Protestant missionaries. Early missionary groups arrived at the Port of Izmir in 1820 and then sprang into Anatolian cities, especially in places that had significant Christian minorities in the Ottoman state. The American Board of Commissioners for Foreign Missions was the premier institution that tried to evangelize mainly Orthodox Christian minorities to Protestantism in the Ottoman state, primarily by opening schools. ${ }^{29}$ Robert College, still one of Istanbul's major educational institutions in modern Turkey, opened in 1863. By the late $19^{\text {th }}$ century, many such schools were open in Istanbul, Trabzon, Antep, Erzurum, Maras, Adana, Aleppo, Harput, Merzifon, Izmir, Tarsus, Antioch, Kilis, and Salonika as they served non-Muslim subjects, namely Armenians and Greeks. ${ }^{30}$ In 1880, there were 331 missionary schools educating over 13,000 students. "By 1913, 450 American missionary schools were teaching 26,000 students in the Ottoman Empire." ${ }^{31}$ One of the most important outcomes of missionary schools and activities was to introduce a wave of nationalism, especially among non-Muslim subjects. As a repercussion, the Sublime Port closed down some schools and tried to limit distribution of missionary publications, especially of Bibles. Interestingly enough, some of the leadership of non-Muslim Ottoman subjects (Armenians), supported the Ottoman authority's attempts to stop the

\footnotetext{
${ }^{29}$ For a review of missionary schools in Turkey, see Süleyman Büyükkarc1, Türkiye'de Amerikan Okullarl (Mikro Basim-Yayim-Dagitim, 2002). Also see three dissertations on the missionary schools in Turkey. Carolyn Mccue Goffman, "More Than the Conversion of Souls': Rhetoric and Ideology at the American College for Girls in Istanbul, 1871-1923" (Dissertation, Ball State University, 2002).; Hugh Gray Johnson, "The American Schools in the Republic of Turkey, 1923-1933: A Case Study of Missionary Problems in International Relations" (Dissertation, The American University, 1975).; Alan Alfred Bartholomew, "Tarsus American School, 1888-1988: The Evolution of a Missionary Institution in Turkey" (Dissertation, Bryn Mawr College, 1989).

${ }^{30}$ Bostanoglu, p 354-355.

${ }^{31}$ Mustafa Aydın and Çağrı Erhan, Turkish-American Relations: Past, Present and Future (London; New York: Routledge, 2004)., p. 28
} 
Protestant proselytizing efforts as they were a threat to their own Orthodox religious practice. They did not want to see conversion of Orthodox Christians (Armenians and Greeks) to American Protestantism. ${ }^{32}$ Leaders of Armenian and Greek communities under the Sublime Porte pressured Ottoman Sultans to cease American missionary activities in their communities. The issue of missionary schools and their activities was one of the major sources of friction between the U.S. and the Ottoman state.

World War I, the Interwar Period and the Relations

Woodrow Wilson was reluctant to enter into World War I, having previously declared neutrality of the U.S. in this "European" war. Public sentiment against the war was high and he did not want to jeopardize his second run for the Presidency in 1916. Wilson maintained American neutrality despite the German sinking of a British ship with American citizens aboard in 1915. However, the U.S. neutrality began seriously deteriorating after unrestricted attacks of German submarines in early 1917. A German attempt at recruiting Mexico to join its side of the war, and their offer to Mexicans of the Southwest United States, practically ended the U.S. neutrality. On April 4, 1917, the U.S. Congress passed a declaration of war against Germany. It was signed into law by Woodrow Wilson two days later. Since the Ottoman Empire and Germany were allies in the war, this put the Sublime Porte in a very difficult position. Germany pressured the Ottomans in 1917 to suspend relations with the United States. The Sublime Porte proceeded to do so, but also apologized to the Americans and did not go any further in

\footnotetext{
${ }^{32}$ Ibid, p. 27
} 
taking action against schools and American Missions. ${ }^{33}$ However, Wilson's Fourteen Points, which were based on his progressive agenda such as self-determination, open agreements, and international cooperation to end the war, threatened the very nature of Ottoman Empire, which was a multi-ethnic state struggling to keep various factions together under its Ottoman umbrella. His twelfth point declared that "the Turkish portion of the present Ottoman Empire should be assured a secure sovereignty, but the other nationalities which are now under Turkish rule should be assured an undoubted security of life and an absolutely unmolested opportunity of autonomous development, and the Dardanelles should be permanently opened as a free passage to the ships and commerce of all nations under international guarantees." 34 Wilson's twelfth point clearly provided the necessary ammunition for non-Turkish minorities to declare their independence from the Sublime Porte in the last days of Ottoman state.

Another major event that affected Turkish-American relations to this day was the mass killings of Armenians by Ottomans during World War I. What is commonly called the "Armenian Genocide" by many was vehemently rejected by Turkey, successor to the Ottoman Empire. ${ }^{35}$ The U.S. Ambassador to the Ottoman Empire from 1913 to 1916, Henry Morgenthau, played a significant role in relaying to America details of the mass deportations of Armenians in 1915. In his memoir, he said that "when the Turkish authorities gave the orders for these deportations, they were merely giving the death

\footnotetext{
${ }^{33}$ Armaoglu, Belgelerle Turk-Amerikan Munasebetleri., p. 19

${ }^{34} \mathrm{http}$ ://avalon.law.yale.edu/20th century/wilson14.asp (Accessed on October 18, 2008)

${ }^{35}$ See books published in Turkish. Levon Marashlian, Ermeni Sorunu Ve Türk-Amerikan Ilişkileri: 19191923, trans. Sen Suer (Belge Yayinlari, 2000).; Sedat Laciner, Ermeni Sorunu, Diaspora Ve Turk Dis Politikasi: Ermeni Iddialari Turkiye'nin Dunnya Ile Iliskilerini Nasil Etkiliyor? (Ankara: Uluslararasi Stratejik Arastirmalar Kurumu, 2008).; Akdevelioğlu, Turk Dis Politikasi: Kurtuluş Savaşından Bugune Olgular, Belgeler, Yorumlar.
} 
warrant to a whole race; they understood this well, and, in their conversations with me, they made no particular attempt to conceal the fact." ${ }^{36}$

However, his treatment of the subject might severely be hampered by some degree of racism on his part. As he pointed out in his memoir, "Armenians of the present day are the direct descendants of the people who inhabited the country three thousand years ago. Their origin is so ancient that it is lost in fable and mystery. There are still undeciphered cuneiform inscriptions on the rocky hills of Van, the largest Armenian city, that have led certain scholars - though not many, I must admit - to identify the Armenian race with the Hittites of the Bible. What is definitely known about Armenians, however, is that for ages they have constituted the most civilized and most industrious race in the eastern section of the Ottoman Empire. From their mountains they have spread over the Sultan's dominions, and form a considerable element in the population of all the large cities. Everywhere, they are known for their industry, their intelligence, and their decent and orderly lives. They are so superior to the Turks intellectually and morally that much of the business and industry had passed into their hands." "37 Bruce Fein argues that "after statehood was lost, Armenians turned to their genocide playbook which exploited Christian bigotries and contempt for Ottoman Muslims. They remembered earlier successful anti-Ottoman propaganda. The United States Ambassador to the Ottoman Empire during the war, Henry Morganthau, was accused of being openly racist and devoted to propaganda. On November 26, 1917, Morgenthau confessed in a letter to President Wilson that he intended to write a book vilifying Turks and Germans to, 'win a

\footnotetext{
${ }^{36}$ Henry Morgenthau, Ambassador Morgenthau's Story (New York: Doubleday, Page and Company, 1919)., p. 309

${ }^{37}$ Ibid, p. 287. Emphasis added.
} 
victory for the war policy of the government.' In his biography, 'Ambassador Morgenthau's Story,' Morgenthau betrays his racist hatred toward Turks ('humanity and civilization never for a moment enters their mind'). ${ }^{, 38}$ When Morgenthau's memoir was published in 1919, it created an unfavorable image of Ottomans among the American populace. Given the fact that many Armenians from Ottoman lands immigrated to the United States, and created a dynamic diaspora community in the U.S., the issue of "Armenian genocide" has become an enduring and thorny issue for Ankara and Washington.

From the U.S. declaration of war against Germany in 1917 to the Lausanne Conference in 1923, relations between two countries were frozen. Relations were not restored to a normal level until a modus vivendi was signed and ambassadors assigned reciprocally in $1927 .{ }^{39}$ The thaw in U.S.- Turkey relations, however, was not free of friction. In 1928, three Turkish students at the Bursa American Girls College were converted to Christianity through the influence of some American teachers. This incident was seen as an attack on secularism by the Turkish state and the school was closed in turn. Despite the objections of the U.S. ambassador to Turkey, Joseph C. Grew, the teachers were tried in Turkish courts and deported to the U.S. ${ }^{40}$

\footnotetext{
${ }^{38}$ Bruce Fein, "Lies, Damn Lies, and Armenian Deaths," Huffington Post.

${ }^{39}$ Rifat Ucarol, Siyasi Tarih (Istanbul: Filiz Kitabevi, 2000)., p. 576

${ }^{40}$ Ayten Sezer, "Osmanli'dan Cumhuriyete: Misyonerlerin Turkiye'deki Egitim Ve Ogretim Faaliyetleri," Hacettepe Universitesi Edebiyat Fakultesi Dergisi no. Special Edition (1999)., p. 179
} 
At the very beginning of the interwar period, ${ }^{41}$ Turks experienced one of the

harshest times in their history. As prominent historian, William Hale, puts it aptly:

\begin{abstract}
Between 1919 and 1923 the Turks passed through the most critical turning point in their modern history. With the defeat of the Ottoman empire in 1918, the victorious entente powers seemed poised to divide up almost all its remaining territory, thus practically extinguishing the Turkish state as an independent actor... Eventually, in 1923, this forced the Turks' former enemies to recognize an independent Turkey within what are virtually its present frontiers. The leader of the resistance movement, Mustafa Kemal Ataturk, then used his traditionally derived authority as a 'Ghazi', the victor in a war against the infidel, to reconstruct the Turkish state on quite untraditional lines - as a secular republic, committed to modernism and a Turkish-ethnic rather than Muslim identity, with himself as president. This outcome was basically determined on the battlefield, not at the conference table. Nonetheless, the military victory would probably have been impossible without adroit diplomacy by Ataturk and his colleagues - in effect, the explanation of the balance of power, and rivalries between the main European states, on which their Ottoman predecessors had relied. After the victory, their overwhelming aim was to secure peace and national security, following years of struggle and loss, by avoiding expansionary projects, and limiting their objectives to what they could achieve by relying on their own resources. ${ }^{42}$
\end{abstract}

Therefore, Turkish foreign policy objectives were very limited, being based primarily upon the idea that Turkey would do everything in its power not to extensively engage in any major world events. The Balkan Wars, World War I, and the War of Independence all occurred in the time frame of about a decade and taught a very costly lesson to the Turkish leadership. Forming alliances and siding with major powers in the European continent that had been rattled with long and bloody wars for more than a century brought heavy tolls to Turks: blood, treasure, and the eventual demise of the Ottoman Empire. ${ }^{43}$ Great suspicion and anxiety among Turkish leadership pervaded relations with any major Western power, including the geographically distant United States. The Turkish mindset held that if these Westerners had an opportunity, they would repeal the Lausanne Treaty of 1923, a peace treaty that recognized Turkey's borders. They would

\footnotetext{
${ }^{41}$ This period covers the time frame from the end of first World War in 1919 to the beginning of the second World War in 1939.

${ }^{42}$ Hale, Turkish Foreign Policy, 1774-2000., p 44-45.

${ }^{43}$ Aptülahat Akşin, Atatürk'ün Dis Politika Ilkeleri Ve Diplomasisi (Turk Tarih Kurumu Basimevi, 1991).
} 
try to revive the Treaty of Sèvres, which sealed the death certificate of the Ottoman

\section{Empire in 1920 and officially partitioned it.}

The Turkish leadership was also aware that there has been a structural change in

the international system with the result that they could no longer rely on it as the Ottoman

Empire had in the late $19^{\text {th }}$ and early $20^{\text {th }}$ centuries. As Mustafa Aydin points out,

The Turkish nation-state emerged out of the ashes of the Empire, it was surrounded with a new international environment which was no longer identical to that which existed prior to the First World War. First of all, the breakup of the Ottoman, Russian and Austria-Hungarian Empires signaled change for the international system. The disintegration of these three empires increased the number of actors in the international system. Most of the new actors were politically unstable and economically weak compared to the victorious powers of the First World War. Furthermore, throughout the war the international system had ceased to be a 'European system' and became a global one in which Europe was no longer predominant. Moreover, the new Turkey was no longer an empire, but a nation-state. It had no desire for territorial conquest and had no power to do so even if it had desired it. It needed a new, realistically sound foreign policy which could respond to the challenges of the new international system without endangering the existence of the state. Ataturk's new directions for Turkish foreign policy were thus enormously important. His foreign policy objectives reflected a departure from the militant expansionist ideology of the Ottoman Empire. He was genuinely concerned with independence and sovereignty, thus with his motto of peace at home, peace in the world; he, while aiming to preserve the status quo, sought a deliberate break with the Ottoman past in virtually every aspect of life. ${ }^{44}$

As the U.S. encountered an unprecedented economic crisis in the Great

Depression of 1929, isolationist policies were rampant. Domestic setbacks forced U.S.

policymakers to deal with internal issues; the swing from Wilson's ambitious

internationalism to avid isolationism was swift, and it limited American involvement in

world affairs. Turkey, a nation-state newly-established on the ashes of the centuries-old

multi-ethnic Ottoman Empire, had to consolidate its political, social and economic

structure. Moreover, Turkey needed to deal with its immediate neighboring powers, such

\footnotetext{
${ }^{44}$ Mustafa Aydin, "Determinants of Turkish Foreign Policy: Historical Framework and Traditional Inputs," Middle Eastern Studies 35, no. 4 (1999)., p. 156
} 
as the Soviets and the European powers. ${ }^{45}$ Ataturk himself was against military alliances and pacts, and believed that those were primary reasons for insecurities among neighboring nations. ${ }^{46}$ In light of early $20^{\text {th }}$-century history, this attitude does not surprise students of Turkish history. Coincidentally, the interwar period overlaps well with Ataturk's rule as the president of Turkey from 1923 to 1938. His ambitious agenda of modernizing Turkey by taking drastic domestic measures in the areas of politics, law, economy, and culture kept him busy. As Aydin argues, "the inter-war period under the leadership of Ataturk and Inonu found Turkey Western in its inclination but jealously guarding against any intimidation that its independence, either economically or militarily, might be jeopardized." ${ }^{47}$ Consequently, engagement with the world in the 1920s and 1930s was not paramount on Turkish or American agendas. ${ }^{48}$

\section{World War II and the Cold War}

Just before the start of the Second World War, young Turkey faced a major hurdle in its twenty-five-year-old history: its founding hero and of president, Mustafa Kemal Ataturk, passed away on November 10, 1938. His massive and radical modernization efforts in domestic affairs, coupled with his strong neutrality in international affairs,

\footnotetext{
${ }^{45}$ Bostanoglu, Turkiye-Abd Iliskilerinin Politikasi., p. 360. See also Oral Sander, Turk-Amerikan Iliskileri 1947-1964 (Ankara: Ankara Universitesi Sosyal Bilimler Fakultesi Yayinlari, 1979).

${ }^{46}$ For a brief history of Turkish-American relations during Ataturk's reign, see Fahir Armaoglu, "Ataturk Doneminde Turk-Amerikan Iliskileri," Ataturk Arastirma Merkezi Dergisi 38, no. 1 (1997).; Akşin, Atatürk'ün Dis Politika Ilkeleri Ve Diplomasisi.

${ }^{47}$ Mustafa Aydin, "Determinants of Turkish Foreign Policy: Changing Patterns and Conjunctures During the Cold War," Middle Eastern Studies 36, no. 1 (2000)., p. 104.

${ }^{48}$ Ataturk himself tried to gain the support of America during the War of Independence and its aftermath. His aim was to create a balancing act against the European powers, such as Britain, France and Italy. However, he was hardly successful in recruiting the U.S. for his cause due to the American positions on late Ottoman era issues such as Wilson's twelfth point, the situation of American missionary schools, and the lingering Armenian problem in eastern Anatolia. Also see Cakmak, Turk Dis Politikasl, 1919-2008.; Akşin, Atatürk'ün Dis Politika Ilkeleri Ve Diplomasisi.
} 
provided breathing room for the young republic. However, the next leader, Ismet Inonu, encountered two nearly insurmountable tasks, to fill the shoes of the founding father and to keep the country away from the oncoming storm of World War II. His rule as the second president of Turkey earned him the title of Milli Sef (National Chief), given the fact that his authoritarian and heavy-handed measures surpassed that of Ataturk's implementation of Westernization and modernization..$^{49}$ In his first year as President, World War II broke out, and he was pressured by the Allied and Axis powers to join in their respective ranks. However, his skilful diplomacy in keeping Turkey from siding with either alliance was successful until late in the war. As Aydin pointed out, "[t]hroughout the war, Inonu came to the conclusion that Turkey's biggest problem after the war would be the prospect of facing all alone the more powerful Soviet Union. In fact, he was convinced that if Turkey entered the war, the Soviets would occupy Turkey either as a member of the Axis or as a 'liberator'. He also foresaw the Soviet post-war domination of Eastern Europe. Hence, he was determined not to give the Soviets an excuse to set foot on Turkish soil." ${ }^{50}$

Although Turkey had followed a very strict neutrality policy during the interwar period, Inonu came to understand that a different shape of international affairs was emerging. The Soviets were pursuing a policy of belligerency, attempting to claim territory from Turkey during the war, and made their intentions clear to both the Great

\footnotetext{
${ }^{49}$ See a detailed account of Ismet Inonu, Metin Heper, Ismet Inönü : The Making of a Turkish Statesman, Social, Economic, and Political Studies of the Middle East and Asia, (New York: Brill, 1998).

${ }^{50}$ Aydin, "Determinants of Turkish Foreign Policy: Changing Patterns and Conjunctures During the Cold War.", p. 105
} 
Britain and the United States at the Yalta and Potsdam Conferences in $1945 .^{51}$ They asked for new arrangements at the Straits (Bosporus and Dardanelles) that would virtually allow the Soviets to control them, as well as Turkey's territorial concessions (Kars and Ardahan) on its border with the Soviet Union. When their demands were rejected by Turkey, the Soviet Union increased its aggressive political pressure. Turkey's policy of non-alignment and its ambiguity during both the interwar war period (19191939) and World War II encouraged the Soviets. In contrast to other European powers' clear positions, Turkish ambiguity invited Soviet pressure. Turkey had no option but to abandon its long-preferred policy of non-alignment during the interwar period. It aligned itself with the Western powers and especially the United States. It can easily be argued that the World War II and its aftermath was a watershed moment that bolstered Turkey's “western vocation.” In spite of Ataturk’s insistence on charting a non-aligned and independent foreign policy during the interwar period, the new leadership under President Inonu came to a realization that the prospect for Turkey's future should closely be tied to emerging post-World War II western security institutions. Otherwise, Turkey's independence would severely be jeopardized by the imminent threat of Soviet invasion. In fact, more westward proclivity in the areas of security and economy for the young Turkish republic had the potential of fully realizing Ataturk's dream of "modern" or “western" Turkey. Increasing Turkish association with the west in this emerging post-

\footnotetext{
${ }^{51}$ Franklin Delano Roosevelt of the U.S., Joseph Stalin of the Soviet Union, and Winston Churchill of Great Britain convened at the Yalta Conference in 1945 to discuss ending World War II and a postwar settlement. Churchill did not object to dividing the world according to both the U.S. and Soviet's spheres of influences. Many historians agree that Yalta Conference is one of the crucial historical milestones in establishing the Cold War, dividing the word according to political, economic, cultural, and ideological spheres, one is based on the capitalism, democracy, and free market economy; another is on the communism.
} 
World War II world would also mean that the young Turkey is qualitatively different than its predecessor, the Ottoman Empire. The move, in the minds of Kemalist elite, would further "disown" the heritage and the association of the past. ${ }^{52}$

From the end of the World War II in 1945 to the early days of $1947,{ }^{53}$ Turkey tried to convince the Western powers, especially the United States, about impending Soviet threats and argued for the first time that Turkey is geographically significant to Western interests since the Soviets could eventually access the Middle East by first invading Turkey. The Turkish argument iterated that Turkey is a key country and that giving in to Soviet pressure would allow the Soviets unmitigated influence in the Middle East and Mediterranean. This argument of the "geographic/ geostrategic significance of Turkey" has since been a useful staple in Turkish foreign policy, enduring despite the changing nature of enemies in the decades to come. I argue that Turkey's claim to a "strategic position" in the heart of three continents of Asia, Europe, and Africa, has been the lifeline of the country in countering major national and international challenges since the end of World War II. It can easily be argued that Turkey delayed facing its issues and challenges, such as the rights of its Kurdish citizens and the claims of an "Armenian genocide," because of its long-standing "significance" and "strategic position" to European nations and the United States.

On February 21, 1947, the British government relayed an important message to U.S. Secretary of State George C. Marshall, indicating that it would stop providing aid to

\footnotetext{
${ }^{52}$ Ibid p. 106

${ }^{53}$ Even some analysts claim that the U.S. military involvement with Turkey started in the middle of the Second World War. See an extensive analysis by Robert Cossaboom and Gary Leiser, "Adana Station 1943-45: Prelude to the Post-War American Military Presence in Turkey," Middle Eastern Studies 34, no. 1 (1998).
} 
Greece and Turkey because of Great Britain's economic woes after World War II. The U.S. had been closely monitoring both Greece and Turkey since both were experiencing serious economic hardship. Moreover, the rise of the Communist faction known as the National Liberation Front in Greece, and well-known Soviet intentions towards Turkey, made President Harry Truman uneasy. He and his top brass realized that unless the U.S. helped, Greece would be taken over by its communists and fall into the hands of the Soviet Union. Moreover, Turkey could not defend itself either militarily or economically against Soviet aggression. The period between the end of the Word War II and early 1947 can easily be assessed as the period when Turkey faced its greatest danger of Soviet threats. ${ }^{54}$ Had Turkey fallen to the Soviets, both the Eastern Mediterranean and the Middle East would have inevitably fallen under communist domination. After much deliberation in the Truman administration, it was clear that protecting Greece and Turkey was vital to U.S. security interests. In his message to the U.S. Congress on March 12, 1947, President Truman said that the U.S. must take immediate action to support Greece and Turkey against growing Soviet expansionism. ${ }^{55}$ President Truman said in his address to a joint meeting of the U.S. Congress: "I believe that it must be the policy of the United States to support free peoples who are resisting attempted subjugation by armed minorities or by outside pressures. I believe that we must assist free peoples to work out their own destinies in their own way. I believe that our help should be primarily through economic and financial aid which is essential to economic stability and orderly political

\footnotetext{
${ }^{54}$ Aydin, ibid p. 108

${ }^{55}$ For a detailed account of how Truman doctrine came into being, see Joseph C. Satterthwaite, "The Truman Doctrine: Turkey," Annals of the American Academy of Political and Social Science 401 (1972).
} 
processes." ${ }^{56}$ Truman emphasized that helping Greece was paramount to the interests of the United States. If Greece would fall into the hands of communism, the neighboring nation, Turkey, could experience serious difficulties, and this wave of communism had the potential of spreading into other European nations. After making the case for an immediate and resolute action, he asked from the U.S. Congress to provide monetary assistance to Greece and Turkey in the amount of $\$ 400$ million. On May 22, 1947, the U.S. Congress passed this historic legislation, later known as the Truman Doctrine, as part of the containment strategy that helped smaller nations resist Soviet expansionism. It was a major milestone for Turkish-American relations given the fact that it was designed to help Turkey and Greece militarily counter Soviet expansion in the region. However, it was not enough to solve the problems of Turkey and Greece when many other European nations were reeling, economically and politically, from the devastating effects of the Second World War. It is worth noting that some communist parties were gaining strength in countries like France and Italy by exploiting massive economic hardship. Even though Turkey had not shot a bullet in the war, and even though its communist factions were almost non-existent, its economy was in shambles and the state could not provide for the basic needs of its population. ${ }^{57}$ An economic aid package for Turkey would ease domestic needs and bolster political stability amid Soviet threats. ${ }^{58}$

\footnotetext{
${ }^{56}$ See his full speech at http://avalon.law.yale.edu/20th century/trudoc.asp (Accessed on October 19, 2008).

${ }^{57}$ Fahir Armaoglu, 20. Yüzyll Siyasi Tarihi, 1914-1980 (Istanbul: Is Bankası Kültür Yayınları, 1984)., p. 443

${ }^{58}$ Ataov, Amerika, Nato Ve Turkiye.
} 
As part of advancing the agenda of containing the Soviet expansion, the United States sought to strengthen France, the Great Britain and Germany economically with the long-range goal of creating a strong and unified Europe that could counter the Soviet Union. Providing monetary aid to European countries, including Turkey, through the IMF and the WB would help revive their economies, adjust macroeconomic stability, and eventually provide market opportunities for American goods. Secretary of State George Marshall delivered a message hinting at an aid package to Europe at Harvard University in June 1947, what was later officially dubbed as the European Recovery Program, though it is widely referred to as the Marshall Plan. Turkey requested to be included in the aid plan although the initial legislation from the U.S. Congress did not include Turkey. On July 4, 1948, Turkey officially participated in the Marshall Plan by signing the Turkish-American Economic Cooperation Agreement. ${ }^{59}$ According to the agreement, Turkey would receive immediate economic assistance in the amount of $\$ 62,376,000$ in grants from 1948 to 1951 , and a $\$ 72,840,000$ loan under very favorable conditions. ${ }^{60}$ When combined with the Truman Doctrine aid package, Turkey received close to $\$ 2$ billion in military assistance and nearly $\$ 1.4$ billion in economic assistance, most of which it used to modernize and mechanize agriculture, improve mining processes, and

\footnotetext{
${ }^{59}$ Fahir Armaoglu, Belgelerle Turk-Amerikan Munasebetleri (Ankara: Turk Tarih Kurumu, 1991)., pp. $168-181$

${ }^{60}$ Ibid p. 181
} 
construct highways. ${ }^{61}$ Agriculture was the single most important area that benefitted from Turkey's receipt of economic aid from the Marshall Plan.

Concurrent with the aforementioned dynamic change in the international system, Turkey also underwent a transformation in domestic politics. One-party rule by the Cumhuriyet Halk Partisi, the Republican People's Party (RPP), as established by Ataturk, was replaced by a multi-party system. ${ }^{62}$ The Demokrat Parti, the Democrat Party (DP), won a stunning victory against the establishment party, RPP, in 1950. The sea change should also be considered significant in terms of what it reveals about the mindset and perception of the Turkish leadership, which allowed a multi-party system as part of integrating to the Western world. It is also imperative to see that there were pragmatic reasons for Turkey moving to the West, namely the immense Soviet threat and the Americans' promise to help Turkey economically and militarily. It can be argued that the DP's support and enthusiasm for joining the Western world, and especially being closer to the United States, was greater than the RPP's. ${ }^{63}$ The RPP represented the establishment of the new republic and it proudly claimed that the RPP was the party of Ataturk, suggesting that it had been established by him. The DP came to power when the

\footnotetext{
${ }^{61}$ Aydin, "Determinants of Turkish Foreign Policy: Changing Patterns and Conjunctures During the Cold War.", p. 110

${ }^{62}$ See scholarship on Turkey's transition to democracy. Tevfik Cavdar, Turkiye'nin Demokrasi Tarihi, Second ed. (Ankara: Imge Kitabevi, 2002).; Serhan Yucel, Türkiye'nin Siyasal Partileri: 1859-2006 (Alfa Yayinlari, 2005).; Feroz Ahmad, The Turkish Experiment in Democracy, 1950-1975 (Boulder, Colo.: Westview Press, for the Royal Institute of International Affairs, London, 1977); Metin Heper, Ali Kazancigil, and Bert A. Rockman, Institutions and Democratic Statecraft (Boulder, Colo.: Westview Press, 1997).; Metin Heper and Sabri Sayari, Political Leaders and Democracy in Turkey (Lanham, Md.: Lexington Books, 2002).

${ }^{63}$ See the account of Turkey's relations with the U.S. under the Menderes' DP. Behramoglu, Türkiye Amerikan Ilişkileri: Demokrat Parti Dönemi.
} 
multi-party system was truly instituted in 1950. Even though many senior members of the DP, including Prime Minister Adnan Menderes, who was later hanged by a military junta in 1960, and Celal Bayar, who was the President of Turkey from 1950 to 1960 and barely escaped the death penalty because of his age, reached high office- but they were considered outsiders, peripheral to the core of political authority in Turkey. Therefore, I argue that the DP's political, economic and security-based attachment to the United States maintained the DP's own legitimacy as the governing party of Turkey, against the establishment, i.e. RPP, and its extensions in the civil and military bureaucracy. It is doubtful that the long rule of the $\mathrm{DP}^{64}$ from 1950 to 1960 would have been possible had it not received economic and military help from the United States. Both domestic restraints and international systemic structures forced Turkey to side with the U.S., sometimes at its own expense.

In the period between 1945 and 1964, Turkish-American relations deepened tremendously but not on equal terms. As Nasuh Uslu puts it, it is the "patron-client state relationship" 65 and he explains characteristics of it as such: First, "[t]here must be a sizeable difference between the military capabilities of the two states. The bargaining power of the patron is greater than that of the client because of the resources it has." ${ }^{, 66}$ Second, "the client plays an important role in patron (superpower) competition. Its position is determined by the availability of other patrons who can render the client the

\footnotetext{
${ }^{64}$ See discussions on democratic transition and the Democrat Party's struggle against the RPP. Tevfik Cavdar, Türkiye'nin Demokrasi Tarihi:1950'den Günümüze (Ankara: Imge Kitabevi, 2008).; Kemal Karpat, Turk Demokrasi Tarihi - Siyasal, Ekonomik, Kulturel Temeller (Istanbul: Afa Yayınc1l1k, 1996).; Kemal H. Karpat, "Political Developments in Turkey, 1950-70," Middle Eastern Studies 8, no. 3 (1972).

${ }^{65}$ Nasuh Uslu, The Turkish-American Relationship between 1947 and 2003 : The History of a Distinctive Alliance (Hauppauge, N.Y.: Nova Science Publishers, 2003)., p. 29

${ }^{66}$ Ibid p. 25
} 
same protection and material support, the mobility of the clients between alternative patrons and degree to which the patron is dependent on the client's services." ${ }^{\prime 67}$ Third, "[t]he patron and the client are closely tied to each other for a recognizable period of time. In almost every issue, the client follows the patron's lead either to get immediate positive rewards or to accumulate goodwill and credit for the future." ${ }^{68}$ Fourth, "[s]ecurity transactions from the patron to the client are more prominent in the relationship. At a low level of threat to the client, other goals such as economic development, regional leadership, and international prestige may gain importance. Arms transfers are powerful tools of influence for the patron." ${ }^{69}$ Fifth, the "[e]lite of the client state absorbs the patron's perceptions of the world through foreign and domestic education." ${ }^{70}$ Sixth, "[t]he patron's goals in continuing the relationship are more complicated: ideological goals (demands for changes in the client's political, economic and social structure), international solidarity (voting cohesion in the United Nations, signing of international agreements, visits between senior statesmen, client announcements of support for the patron), strategic goals (demand for bases).,"71

As these characteristics depict a fully dependent nation to its patron, Turkey's position vis-à-vis the United States from 1945 to 1964 was of one-dimensional foreign policy orientation as Turkey bet its hands on this heavy dependence. In this period, "[a]s a result, Turkey's need for foreign aid became an integral part of its foreign as well as

\footnotetext{
${ }^{67}$ Ibid

${ }^{68}$ Ibid

${ }^{69}$ Ibid

${ }^{70}$ Ibid

${ }^{71}$ Ibid
} 
domestic policy." 72 Converging Turkey's interests to those of the U.S.' became the cornerstone of Turkish foreign policymaking, which was, at the time, considered to be a realm of a small elite cadre of the nation. Turkey's willingness to be part of Western political and security structures also proved viable when it sent Turkish troops to Korea in 1950. The move aimed to show the European powers in general and the United States in particular that it was willing to go the extra mile to be part of the North Atlantic Treaty Organization (NATO). Even though Turkey lobbied hard to enter into NATO in 1948 when it was established by the U.S. and major European powers, it was not possible until 1952, when both Greece and Turkey were admitted to the organization. The Turkish entry into NATO was the culmination of Turkey's integration into the Western world, not only in economic terms but also in collective security terms.

Three major outcomes emerged from Turkey's NATO membership: First, its economic and security woes were eased since it was "more" connected to the Western world, specifically to the United States. Second, the membership supported the proWestern policies of the Democrat Party as it took power for two years. Its arch-nemesis, the RPP, was temporarily silenced by the DP's foreign policy success. Third, the DP would use this success to promote its rhetoric of Turkey as "Little America," alluding to the perception that Turkey was becoming prosperous, powerful, and Western like the United States. This image of "Little America" has positive and negative connotations for the Democrat Party. First, it granted more political ammunition for Westernization, which the founding father of Turkey, Ataturk, characterized as the "ultimate contemporary level

\footnotetext{
${ }^{72}$ Aydin, "Determinants of Turkish Foreign Policy: Changing Patterns and Conjunctures During the Cold War.", p. 110
} 
of civilization". However, both the senior leadership of the Republican People's Party and small, emerging left-leaning political factions were using this depiction against the DP, portraying it as too American. The survey of daily papers such as Cumhuriyet and Son Posta at the time reveals unease about the DP's rhetorical flop.

Throughout the 1950s, Turkey further improved its relations with the U.S., especially in military affairs. "Under a series of bilateral and secret agreements, important U.S.-cum-NATO facilities were constructed in Turkey, including, most notably, an air base at Incirlik, near Adana, with other bases at Karamursel, Cigli, and Diyarbakir, and radar stations at Karamursel, Sinop, Samsun, Trabzon, Belbasi, and Diyarbakir. Naval facilities and storage centers were established at Iskenderun (Alexandretta) and Yumurtalik. The U.S. Air Force stationed strike aircraft armed with tactical weapons on Turkish soil, under an agreement reached in 1957, and by the late 1960s there were about 24,000 U.S. military personnel on Turkish territory. U.S. aid, equipment and training were also instrumental in modernising the armed forces and in propping up the Turkish economy. Total delivered U.S. military assistance to Turkey between 1948 to 1964 came to $\$ 2,271$ million, plus $\$ 328$ million in deliveries of surplus equipment. Meanwhile, Western economic aid to Turkey between 1950 and 1962 totaled around $\$ 1,380$ million, of which the vast majority came from the United States. To put these into context, Turkey's annual average exports during the 1950 s came to around $\$ 320$ million, and its annual imports to around $\$ 400$ million. Turkey would almost certainly have found it 
impossible to maintain a fairly high rate of economic growth during 1950s (as it did), and greatly strengthen its defences at the same time, without this assistance."73

\section{Disappointments and Crises}

The relationship between Turkey and the U.S. was not free of friction or crisis. In fact, major crises took place in the 1960 s. ${ }^{74}$ One of the initial disappointments occurred in 1958 when Lebanon called for immediate U.S. assistance as violence escalated between its Muslim and Christian populations. The U.S. immediately dispatched its support from Adana-Incirlik airbase in Turkey, without consulting its counterparts in the Turkish government. Opposition leader Ismet Inonu, powerful leader of the RPP and former President of Turkey, fiercely attacked the Menderes government and claimed that Turkish sovereignty was compromised. To a certain extent, the opposition was not ready to see the Incirlik air base used outside of its primary mission of containing the Soviet Union. The U.S. action was perceived as prioritizing American interests over Turkish ones even if they might damage Turkish interests, as by intervening in Lebanese domestic affairs. ${ }^{75}$ The second incident involved an American U-2 spy plane that was shot down in 1960 by the Soviets while flying over the Soviet Union. The Soviet Union accused Turkey of being part of a covert surveillance mission of the U.S. as the U2 had been ferried through the Incirlik air base. Two years after the Lebanon affair, the incident alarmed Turkey. In

\footnotetext{
${ }^{73}$ Hale, Turkish Foreign Policy, 1774-2000., p. 123

${ }^{74}$ See a review of the relationship from a Turkish perspective. Oral Sander, Türk-Amerikan Ilişkileri, $1947-$ 1964 (Ankara: Ankara Universitesi, 1979).

${ }^{75}$ George S. Harris, Troubled Alliance; Turkish-American Problems in Historical Perspective, 1945-1971, Aei-Hoover Policy Studies, (Washington: American Enterprise Institute for Public Policy Research, 1972)., p. 67
} 
turn, Turkey asked the U.S. to inform Turkish authorities about their flight details from Incirlik. $^{76}$

Months before the toppling of Prime Minister Adnan Menderes by a military junta in 1960, the Menderes government agreed on the installation of "15 Jupiter intermediate-range ballistic missiles, armed with nuclear warheads, ... [t] hey were owned by Turkey, but the U.S. retained custody of the warheads, and they could only be used with the joint permission of the U.S. and Turkish governments. Together with two similar squadrons of Jupiter deployed in Italy, they were targeted on 45 of 129 Soviet mediumand intermediate-range missiles aimed at Europe."77 Public opinion in Turkey was sharply divided on the issue. On the one hand, some argued that this Turkish and American "offensive" would provoke a Soviet attack. Alternatively, proponents advocated that Turkey would be more secure against possible Soviet threat since it would show that Turkey had the capability of responding to it. They also added that this would prove that the U.S. was committed to Turkey's protection against any Soviet aggression. $^{78}$

The installation of Jupiter missiles in Turkey was not possible until 1961. However, the very next year, this installation caused one of the most pressing crises in Cold War history when the Soviets asked the U.S. for removal of missiles in Turkey in return for the removal of Soviet missiles from Cuba. Even though the details of the deal between President Kennedy and Khrushchev were not revealed immediately, it was clear

\footnotetext{
${ }^{76}$ Ibid.

${ }^{77}$ Hale, Turkish Foreign Policy, 1774-2000., p. 133-134

${ }^{78}$ Ibid p. 134
} 
to the Turkish leadership that the U.S. would make its own decision when it came to its national security interests- without consulting or informing its allies. ${ }^{79}$ Considering previous incidents, the Cuban missile crisis was a watershed moment in Turkish foreign policymaking. With this move, the Turkish foreign policy establishment understood that Turkey needed diversification of its foreign policy, including finding new ways to develop friendships outside the Western world, like with its Middle Eastern neighbors. This analysis of diversification of the foreign policy agenda proved that Turkey could not prosper and stay safe by aligning itself only with the U.S. Tensions only mounted with the Cyprus crisis in the mid-1960s, and then grew further through the mid-1970s. It also demonstrated that the perception of hotly-contested issues differed in both sides. Issue of Cyprus and its Impact on the U.S.-Turkish Relations

The rising tension between the Greek majority and Turkish minority in Cyprus proved that this island had the potential to severely jeopardize the relationship between Washington and Ankara in the early 1960s. ${ }^{80}$ Even though the London-Zurich Treaty of 1959 paved the way for the creation of the Republic of Cyprus with guarantees from three outside powers, namely the United Kingdom, Turkey, and Greece, the United States had to involve itself in the conflict as a result of the systemic changes in international relations after 1945. When Makarios, the first President of the Republic of Cyprus and Archbishop of the Greek Orthodox Church, tried to incorporate the island into Greece -

\footnotetext{
${ }^{79}$ Ibid p. 135

${ }^{80}$ See Suha Bolukbasi, The Superpowers and the Third World: Turkish-American Relations and Cyprus (Lanham, MD: University Press of America, 1988).; Parker T. Hart, Two Nato Allies at the Threshold of War: Cyprus: A Firsthand Account of Crisis Management, 1965-1968 (Durham: Duke University Press, 1990).; Rauf Denktas, The Cyprus Triangle (London: Allen \& Unwin 1982).; Nasuh Uslu, The Cyprus Question as an Issue of Turkish Foreign Policy and Turkish-American Relations, 1959-2003 (Hauppauge, N.Y.: Nova Science Publishers, 2003).
} 
the idea of ENOSIS - Turkish Cypriots grew uneasy and faced a growing threat of violence in the island. It is obvious that the tension between Greece and Turkey increased tremendously as even the United States was wary of the fact that these two NATO allies were endangering the alliance's cohesion against the Soviet Union. The United States wanted to keep the alliance intact and contain the Soviet influence on the island, especially considering that Cypriot communists were powerful and that Makarios was in regular contact with Moscow. ${ }^{81}$ Cyprus' constitutional crises of 1960 and 1963, plus increasing intercommunal violence between majority Greek Cypriots and minority Turkish Cypriots, further strained the relations between Athens and Ankara. Turkey demanded from the U.S. that it needed to act proactively on the issue. Otherwise, Ankara would intervene militarily. The possibility of military intervention in Cyprus, which threatened to partition the island, at last resulted in a strong letter from U.S. President Lyndon B. Johnson. It called for restraint on the parts of Turkish leaders and favored Greece over Turkey. What was later known as the Johnson Letter of June 5, 1964 sent deep shockwaves through Turkish domestic politics. Feelings of betrayal and doublestandards among the Turkish elite were rampant given the fact that Turkish observance of pro-Western alliance since 1945 had left Turkey with limited options in countering Soviet expansionism. The U.S. was now restraining Turkey to protect Turkish Cypriots from another NATO ally, Greece. President Johnson also emphasized to Prime Minister Inonu that he not use military equipment of U.S. origin in the case of Cyprus invasion.

I wish also, Mr. Prime Minister, to call your attention to the bilateral agreement between the United States and Turkey in the field of military assistance. Under Article IV of the agreement with Turkey of July 1947, your government is required to obtain United States consent for the use

\footnotetext{
${ }^{81}$ T. W. Adams, "The American Concern in Cyprus," Annals of the American Academy of Political and Social Science, no. 401 (May 1972).
} 
of military assistance for purposes other than those for which such assistance was furnished. Your government has on several occasions acknowledged to the United States that you fully understand this condition. I must tell you in all candor that the United States cannot agree to the use of any United States supplied military equipment for a Turkish intervention in Cyprus under present circumstances. ${ }^{82}$

The harsh nature of the letter stirred reactions from both the Turkish political elite as well as the populace. Anti-American sentiment increased and mass protests were organized. The U.S. even asked its military personnel in Turkey not to wear their uniforms in public. As indicated earlier, growing unease about the U.S. consideration of Turkish national interests on key foreign policy decisions, and Washington's letter on Cyprus, made it clear that Turkey needed more multi-faceted foreign policies. ${ }^{83}$ The Turkish political establishment, including Prime Minister Ismet Inonu, came to understand that Turkey looked like a satellite state of the U.S. and henceforth considered a new foreign policy orientation such as rapprochement with the Soviet Union. It could serve as a balancing act against the U.S. Given the rise of left-leaning political constituencies, not only in Europe, but also in Turkey, it made political sense for the Turkish leadership to re-orient foreign policy. However, this new foreign policy orientation did seek neutrality in conflicts in the Middle East in the mid-1960s. It can easily be argued that this was, in essence, a mental shift in Turkish foreign policymaking, and it did not mean that Turkey turned its face away from the Western alliance. Rather, it was now looking at its Western alliance from a more realistic perspective and prioritizing

\footnotetext{
${ }^{82}$ Lyndon B. Johnson and Ismet Inonu, "President Johnson and Prime Minister Inonu: Correspondence between President Johnson and Prime Minister Inonu, June 1964, as Released by the White House, January 15, 1966," Middle East Journal 20, no. 3 (Summer 1966).

${ }^{83}$ See the impact of Cyprus question on Turkish-American relations. Nasuh Uslu, Türk - Amerikan Ilişkilerinde Kıbrıs (Ankara: 21. Yuzyil Yayinlari, 2000).; Uslu, The Cyprus Question as an Issue of Turkish Foreign Policy and Turkish-American Relations, 1959-2003.
} 
its national interests, trying to find new ways to maximize them with possible partners such as neighboring nations, even the Soviet Union.

By 1974, the situation on the island of Cyprus had deteriorated further. The nonaligned policies of President Makarios strained the island's relationship with Greece. Greek support for a military coup against Makarios, and an eventual replacement of Makarios by Nikos Sampson's junta government, alarmed Turkey and raised fears of unification with Greece. According to the Turkish view, unification would jeopardize Turkish national security interests due to the strategic nature of the island in the Mediterranean. This literally meant, to the Turkish political elite, that the balance of power in the Mediterranean Sea and Aegean Sea would be tipping against Turkish interests. ${ }^{84}$ Hence, Turkish armed forces, with the approval of Prime Minister Bulent Ecevit, went ahead with military intervention on July 20, 1974. The two phases of Turkish military advances in the island worried the United States, despite the fact that the U.S. was deeply embroiled in its own crises, namely the Watergate scandal and the Vietnam War. Angered by Turkish action on the island, and under the pressure from Greek constituencies in the U.S., in February 1975, the Congress passed a resolution of arms embargo against Turkey. The embargo banned "military sales and aid to Turkey until the president could show that substantial progress had been registered towards a settlement of the Cyprus problem." 85 The U.S. Congress wanted to send a message not only to Turkey but to President Ford, who had focused much of his energy on the postNixon political scenery. Ford was perceived by the Congress not to be giving his full

\footnotetext{
${ }^{84}$ Oktar Turel, Akdeniz'de Bir Ada: Kktc'nin Varolus Oykusu (Ankara: Imge Yayınları, 2002).

${ }^{85}$ Hale, Turkish Foreign Policy, 1774-2000., p. 160
} 
attention to the Cyprus problem. The arms embargo defined the relationship between Washington and Ankara until President Jimmy Carter was able to lift it. Subsequently, Turks reacted swiftly by suspending all American activities on Turkish soils except "those deemed to have purely NATO function." Limiting the ability of American functions in such a strategic location burdened the U.S. interests and clearly showed the leverage that Turkey could use against any future problems with the U.S. The struggling U.S. administration faced Congress' imposition of the arms embargo on Turkey by finding creative ways to ease the tension. Ford administration provided financial aid to Turkey, which in turn convinced Turkey to let American functions to continue on Turkish soils in early 1976. However, lifting of the embargo was not possible until 1978.

Concurrently with the issue of Cyprus, Turkey and the U.S. had another pressing problem in the late 1960s and early 1970s: namely the implication of the US "war on drugs" and Turkey as a source of opium. The growing problem of narcotics and drug usage was one of leading domestic American problems that preceded Richard Nixon's Presidency. He plainly promised in his election campaign that he would fight against drug production, distribution and usage. He coined the term "War on Drugs" and showed his resolute implementation of drug prohibition policies with the Comprehensive Drug Abuse Prevention and Control Act of 1970. One of the important components of the "War on Drugs" policy was to control the illegal trafficking of opium coming from Turkey. Pressured throughout the 1960s, Turkey took measures to limit the growing of opium from thirty cities to four cities with more restrictions imposed ${ }^{86}$ However, it did

\footnotetext{
${ }^{86}$ Aydin, "Determinants of Turkish Foreign Policy: Changing Patterns and Conjunctures During the Cold War."
} 
not satisfy the U.S. authorities, and Turkey was singled out in a report by the Bureau of Narcotics and Dangerous Drugs, claiming that "about 80 percent of the heroin illicitly introduced into the United States was derived from opium diverted from Turkish production. ${ }^{, 87}$ Turkish authorities swiftly reacted to the claim, arguing that it was not possible that Turkey was the primary supplier of heroin in the U.S. It also railed against Turkey being singled out - the report did not mention of any other country - and questioned the integrity of the report. Turkey had a hard time balancing the U.S. requests to control opium production on the one hand and its need to substitute new products for Turkish farmers on the other hand. Eventually, Turkey banned opium production to satisfy U.S. demands after the 1971 military coup. ${ }^{88}$

Washington's perception of Turkey as the "sole supplier" of opium to the U.S. was coupled with other hard-pressing international issues, such as the Cyprus problem that underscored the growing unease in Turkish-US relations. Consequently, relations between Ankara and Washington were unsettled and difficult from the mid-60s to the late-70s. Above all, the Turkish political elite understood that the U.S. would always prioritize its own national interests over those of Turkey, and they recognized a need to worry about Turkey's own strategic calculations. Realism replaced their naïve perspective on international politics. Given the fact that harsh bifurcation of power politics of the Cold War in the international system had began to thaw under the détente, Turkey saw in the reduction of superpower tension a window of opportunity for a cautious opening to the Soviets and other neighboring nations. However, diversification

\footnotetext{
${ }^{87}$ Harris, Troubled Alliance; Turkish-American Problems in Historical Perspective, 1945-1971., p. 192

${ }^{88}$ See a discussion on the role of opium on Turkish-American relations. Cagri Erhan, Beyaz Savaş: TürkAmerikan Ilişkilerinde Afyon Sorunu (Ankara: Bilgi Yayinevi, 1996).
} 
of foreign policy was not easy since Turkey did not have either meaningful engagements with its neighbors or power capabilities in the 1960s and 1970s. As Aydin stated,

1945-60, during which Turkey's foreign policy was dominated by total Western dependence, was followed by a period of disillusionment with the West, late detente with Eastern bloc and rapprochement efforts with the Third World (1960-70). The 1970s, in addition, saw a pattern of alienation from the West encouraged by the Cyprus crisis of 1974, which in turn showed Turkey the cumulative result of the foreign policy it had been following since the end of the Second World War: loneliness in the international arena. Hence, the 1970s witnessed Turkey's efforts to come back to the international arena as a reliable and friendly nation, just as she was during the inter-war period. ${ }^{89}$

Despite rocky relations between Turkey and the U.S. throughout the 1970s, Ankara's relative strategic importance increased due to renewed Cold War tension between Soviets and Americans in the first half of the 1980s. Washington provided more military and economic aid to Ankara to bolster its ally against any possible Soviet aggression. In 1984, U.S. military aid to Turkey reached its peak of $\$ 715$ million. ${ }^{90}$ Another important dimension of the discussion is that the Turkish military intervened in the government on September 12,1980, for the third time in the last three decades. As the generals involved were pro-American, and since the coup ended civil unrest and political uncertainty in the country, intervention was welcomed by Washington. American officials preferred to deal with a "reliable partner" on the Turkish side as they attempted to counter renewed Soviet activism. Six months prior to the military intervention, Turkey and the U.S. signed the Defense and Economic Cooperation Agreement (DECA) to deepen their military and economic partnership and reclaim time and resources lost in the 1970s. Given the fact that the U.S. lost its most important strategic ally in the Middle East, Iran, to that country's Islamic revolution in 1979, keeping Turkey in the Western

\footnotetext{
${ }^{89}$ Aydin, p.115

${ }^{90}$ Hale, ibid p. 165
} 
alliance had become more significant. Kenan Evren, commanding general in the 1980 coup d'état, presented his coup as a means of preventing Turkey from slipping into the hands of communism, fascism and religious sectarianism.

A transition to democracy started with a new constitution, which was written by the military in 1982, and free elections were held in late 1983. U.S.-educated Turgut Ozal became the Prime Minister. He was determined to do three things: 1) liberalize the Turkish economy and make it internationally competitive, 2) deepen political and economic involvement with the United States, and 3) assert civilian control over Turkish politics. To these ends, he started a series of reforms in the economic realm, including providing a more appealing business environment for foreign investors. He helped pass legislation to reform the state-run economy and took bold measures to shift it to an export-oriented, free-market economy. What is called the "Ozal revolution" is the reason for structural change in economic outlook that integrated Turkey into the global economy as the country had already done with its security institutions in the early 1950 s. As a result of him being educated in the U.S., he admired the values of the free market economy, American secularism and democracy. He aimed to make Turkey an advanced industrialized democracy modeled after the United States. ${ }^{91}$ As Aral pointed out, "Even his critics agree that liberalization and transition to a free market economy are among his most durable legacies." ${ }^{.92}$ Ozal also led a mental shift in the Turkish political elite, away from the role of a subordinate to the U.S. to one of a partner. He thought that requesting

\footnotetext{
${ }^{91}$ Berdal Aral, "Dispensing with Tradition? Turkish Politics and International Society During the Özal Decade, 1983-93," Middle Eastern Studies 37, no. 1 (2001).; Mehmet A. Birand and Soner Yalcin, The Özal: Bir Davanin Öyküsü (Istanbul: Dogan Kitap, 2001).

${ }^{92}$ Ibid p. 84
} 
economic and military aid from Washington perpetuated the disparate relationship and consequently placed Turkey under psychological and strategic subordination. Therefore, he voiced a new vocabulary in his new strategy, calling for "trade not aid" in political dealings with Washington. Rather than complaining about increases in aid packages given to Greece, he engaged in opening up more commercial opportunities and eliminating trade barriers not only with the U.S., but also with Europe. The new-found self-confidence, especially after the instable politico-economic environment of the 1970s, spurred impressive economic growth of 5\% annually, along with an increase of Turkish exports from $\$ 2.9$ billion in 1980 to $\$ 20$ billion in $1990 .{ }^{93}$

Ankara's relations with Washington in the mid to late-1980s were accompanied by a new soul-searching that reached an all-time high in the early 1990s. Mikhael Gorbachev's ascension to power in 1985 set the stage for a shattering of the international system and the end of the Cold War, which was based upon systemic rivalry between two superpowers. Gorbachev's bold initiatives in ending rivalries with Washington would also result in the U.S. questioning the future of its security and political commitments in the region. As one can imagine, the Turkish political elite realized that the "utility of Turkey" to the Western alliance was in question as the long-standing Soviet threat was about to disappear. Turkey's presumed strategic role and relative significance to the West as a bulwark against Soviet expansionism was losing its immediate value and that prompted the Turkish political elite to find new ways to "situate" Turkey in this uncharted territory. Ankara faced new and challenging tasks as its long-fixed mindset,

\footnotetext{
${ }^{93}$ Sedat Laciner, "Turgut Özal Period in Turkish Foreign Policy: Özalism," USAK Yearbook of International Politics and Law 2 (2009).
} 
reliant upon the now-extant realities of the Cold War, adjusted to emerging post-Soviet environment. 


\section{CHAPTER III: THE SHADOW OF THE GULF WAR AND THE KURDISH}

\section{QUESTION}

The young Turkish Republic has experienced four broadly defined transformative periods $^{94}$ in its foreign policy. The first one was its establishment as a country whose identity was based on a Turkish nation-state ideal on the republican premise. Even though it has defined its course forward as "western oriented," its foreign policy can be categorized as non-aligned between 1923 and 1945. The second is the exclusive integration of Turkey into western security and political institutions during the Cold War era (1945-1990) largely because of the imminent threat of Soviet expansion. The third period (1990-2003) is that of the post-Cold War environment, which signifies the demise of Soviet Union and the threat therefrom, but also brings a wide array of challenges and opportunities for Turkish foreign policy making. During this period, Turkey had to face growing threats of instability in the neighboring regions like the Middle East, the Caucasus, and the Balkans. Especially, the Gulf War of 1990-91 seriously impacted the direction of Turkey's Kurdish question. The main theme of this period for Turkey was to situate itself in the emerging post-Cold War era while undergoing serious domestic political and economic challenges. The fourth period signaled the beginning of a new era of activism in Turkish foreign policy, which started roughly in 2003 with the Turkish rejection of U.S. troops being stationed on Turkish soil to overthrow Saddam regime in

\footnotetext{
${ }^{94}$ Current Turkish minister of foreign affairs Ahmet Davutoglu identifies four restorations of Turkish politics and foreign policy starting with Tanzimat in 1876, first constitutional era in the Ottoman state. See his speech at the Brookings Institution, http://www.brookings.edu/ /media/Files/events/2010/1129_turkey/20101129_turkey.pdf (Accessed on December 20, 2010).
} 
Iraq. It should also be noted that the Justice and Development Party's (JDP) ${ }^{95}$ assertive new foreign policy reflected the growing role of the Turkish populace in foreign policy making. While keeping its western orientation, Turkey began to assert itself as an independent and self-confident actor who could heavily invest in the Middle Eastern affairs that Turkey ignored for a long-period of time. It should also be noted that this activism in foreign policy was a reflection of a wider transformation in Turkey's own self-perception and the definition of its core interests. While systemic changes in the international system profoundly impacted both Turkish domestic and foreign policy the author, however, looks at the transformation of Turkish domestic and foreign policy not only as a function of changes in the international system but rather as a function of the interplay of agency and systemic variables, thus providing the framework to explain the evolution of Turkish-American relations in the post-Cold War environment. It is really key to understanding the dynamics of this emerging post-Cold War world, but one also needs to weave some of the major events into the discussion such as the Gulf War, the emergence of the de facto Kurdish state in northern Iraq, the September $11^{\text {th }}$ terrorist attacks, and the Iraqi War of 2003.

\section{The Post-Cold War Security Thinking and Turkish Calculations}

NATO, the prime western collective security organization, was in soul-searching mode after the dissolution of the Soviet Union. It lacked a "sense of meaning" because of losing its primary mission, which was to counter Soviet expansionism. Re-orienting its core mission to solving security challenges of the post-Cold war environment required extensive discussions and deliberations. Acquiring new missions in order to replace the

\footnotetext{
${ }^{95}$ Adalet ve Kalkinma Partisi (AKP) in Turkish.
} 
already dissolved "Soviet threat" was not easy. It was also true for Turkey as it sought to "define" or "find" its proper place in this new security environment. Staying in NATO's orbit not only for its security umbrella but also re-asserting its "Western vocation" have been two of the main foreign policy challenges for Turkish policy makers. Discussions about the diminished, if not lost, role of NATO would also be severely affecting Turkey's unique strategic position during the Cold War. "Situating" Turkey in the new western security apparatus was a challenge because the "utility" of Turkey as a buffer-zone or bulwark against the Soviet expansion was no longer applicable. Turkey's long-desired entry into the European Community, then named the European Union, has not been realized. Moreover, it has become more difficult to argue the "unmatched position" of Turkey back in the good old Cold War days since the relative "geostrategic value" of Turkey in relation to Europe diminished significantly. As William Hale put it, "Turkey might be seen as strategic and political liability rather than an asset to the West strategically because it had a host of complex regional security concerns (which, it was apparently assumed, were not shared by the Western powers), and politically because of its non-membership of the EU, its internal Kurdish problem, poor human rights record, and conflicts with Greece. Turkey's leaders liked to present their country to the Western powers as a bridge between Europe and the Middle East and central Asia, but there was a risk that western Europe might prefer to see it as a barrier against a hostile 'other,' left outside European structures." ${ }^{96}$ This led to major soul-searching for Turkish foreign policy makers. They needed to find some ways to "situate" Turkey's standing in this new world (dis)order in which many of the assumptions of the previous period no longer

\footnotetext{
${ }^{96}$ Hale, Turkish Foreign Policy, 1774-2000., p 192-3.
} 
held. ${ }^{97}$ Some in Turkey saw the opportunity to open it up to the newly independent Turkic states in the Central Asia and the Caucasus. However, they steadfastly argued that this new opening for the Turkish foreign policy is "complementary rather than contradictory to its links with the Western powers." 98

As laid out above, the third transformative period in Turkish foreign policy began at the end of the Cold War dichotomy and the collapse of the Soviet Union. Turkey was safe from Soviet expansionism, but faced a complex and dynamic web of new challenges ranging from ethnic separatism, the rising tide of terrorism, the increasing tension and conflicts in the Balkans, the Caucasus and the Middle East in Turkey's immediate neighborhood. Countering these challenges was not easy and required the involvement and cooperation of international organizations, especially NATO, as a result of its collective security commitments during the Cold War. However, engaging nonconventional security threats was difficult given the fact that the NATO was a collective security organization that was designed primarily to respond to conventional threats emanating from the Soviets. In line with Turkey's concerns and changing perception of the foreign policy challenges, heads of states from NATO member countries met in Rome in November 1991. They identified NATO's new mission of dealing with challenges and

\footnotetext{
${ }^{97}$ See extensive discussions, Nasuh Uslu, Turk Dis Politikası Yol Ayrımında: Soğuk Savaş Sonrasında Yeni Sorunlar, Yeni Imkânlar Ve Yeni Arayışlar (Ankara: Anka, 2006).; Cuneyt Yenigun, Soğuk Savaş Sonrasında Tbmm Ve Dış Politika: Belgeler-Yorumlar (Ankara: Nobel, 2004).; İnan, Dis Politika.; Ramazan Gozen, Amerikan Kiskacinda Dis Politika: Korfez Savasi, Turgut Ozal Ve Sonrasi (Istanbul: Liberte, 2000).; Baskın Oran, Kalklk Horoz: Cekic Guc Ve Kurt Devleti (Istanbul: Bilgi Yayınevi, 1996).

${ }^{98}$ Hale, ibid p. 193
} 
instability outside of NATO areas. ${ }^{99}$ It was argued that new emerging threats were emanating from ethnic tensions, cross-border issues, proliferation of weapons of mass destruction and other non-traditional security threats. Defining such an extended mission of engagement for NATO would not decrease Turkey's "relative value" in the western world; instead, it would put Turkey at the center of engagement given that NATO was now effectively extending its reach to the south and east of Turkey's borders. The test of Turkey's "utility" for the Western world and NATO did not have to wait long: The invasion of Kuwait by Saddam Hussein brought a global crisis to Turkey's door and tested its new post-Cold War role in a profound and a very unexpected fashion. The Gulf War and the U.S. Engagement in Iraqi Kurdistan

The prolonged Iran-Iraq War (1980-1988) left both sides devastated both economically and politically. Though Iraq had accumulated more than $\$ 30$ billion in its reserves by 1980, its infrastructure was almost entirely demolished after 8 long years of war with its neighbor. It became indebted to its creditors in amounts of about $\$ 100$ billion by 1988. Most of this money was owed to its oil-producing neighbors, Saudi Arabia and Kuwait. With its war with Iran ending without victory, Saddam Hussein had a ruined Iraq whose reconstruction would cost hundreds of billions of dollars. ${ }^{100}$ Adding insult to injury, the price of crude oil, the main source of income for Iraq, was on its lowest-ever prices in international market. For example, crude oil was valued at nearly $\$ 20$ per barrel

\footnotetext{
${ }^{99}$ F. Stephen Larrabee et al., Nato's Mediterranean Initiative : Policy Issues and Dilemmas (Santa Monica, Calif.: Rand, 1998).

${ }^{100}$ Daniel Byman, "After the Storm: U.S. Policy toward Iraq since 1991," Political Science Quarterly 115, no. 4 (2000-2001).
} 
in July 1987 but dipped to $\$ 12.28$ per barrel in October $1998 .{ }^{101}$ For Saddam, this was devastating since his iron fist rule was endangered when Iraqis could not achieve basic subsistence. If he could not quickly find sources of income to revive the Iraqi economy, his grip on power might be jeopardized, given the fact that he had ascended to power by ruthless means in 1979. It is important to note that he escaped as many as four assassination attempts due to growing unrest in Iraq after the war. He needed to divert his people's energy and find ways to ease Iraq's financial woes. However, he could get it from neither the Soviet Union, because of its own financial malaise and its disastrous departure from Afghanistan, nor from western Europeans, who seriously objected to Saddam's treatment of his own people, especially the Kurds. Given the fact that Kuwait is a small country that enjoyed the benefits of a burgeoning economy heavily dependent on oil, Saddam insisted that Kuwait was responsible for the dramatic collapse of oil prices. He also thought that Kuwait had historically been a natural part of Iraqi territory (in the Ottoman domain of Basra) until the British colonial rule established during World War I. Combining all of these reasons, Saddam Hussein invaded Kuwait on August 2, 1990. It was not clear whether he was also considering the collapse of the Cold War international system in his calculation as the Soviet Union ended the war in Afghanistan with defeat in 1988, and discussions of secessions among Soviet republics were widespread in early 1990. Regardless of Saddam's understanding of the emerging international system, his main motivation was to maintain his grip on power by exploiting the weak state in his neighborhood. That happened to be Kuwait.

\footnotetext{
${ }^{101} \mathrm{http}: / / \mathrm{www}$. indexmundi.com/commodities/?commodity=crude-oil-brent\&months=300 (Accessed on December 20, 2010)
} 
The Gulf War conflict has hardly been a regional one from the outset. ${ }^{102}$ The invasion of Kuwait by Iraq sparked an immediate opposition from neighboring nations, especially Turkey and Saudi Arabia; the leading world powers, the United States, western European nations, and Russia; and the international community as embodied by the United Nations. On August $2^{\text {nd }}$, the United Nations Security Council (UNSC) Resolution 660 swiftly "condemns Iraqi invasion of Kuwait... demands that Iraq withdraw immediately and unconditionally all its forces to the positions in which they are located on 1 August 1990." ${ }^{103}$ As Turkey was about to make sense of the changing international environment, the eruption of war next door put the country in a very difficult position because it was forced to take a position of engagement one way or another- this in opposition to its traditional policy of non-involvement in Mideast affairs. Throughout the Cold War, Turkey followed pro-Western policies, worked closely with the United States on key strategic security issues. Apart from few minor occasions, Turkey maintained distance from Middle Eastern affairs, refraining from involvement with any major problems in Arab nations. ${ }^{104}$ It could be attributed, in part, to the nature of the international system, the ideological preferences of Turkish political establishment, and pro-Soviet tendencies among some of the Middle Eastern nations. First of all, Turkey’s distinct position in the intersection of Europe, Balkans, the Caucasus, the Middle East, and the emerging new Central Asian Turkic republics was about to open new

\footnotetext{
${ }^{102}$ Mahmut Bali Aykan, "Turkey's Policy in Northern Iraq, 1991-95," Middle Eastern Studies 32, no. 4 (1996).

${ }^{103}$ http://daccess-dds-ny.un.org/doc/RESOLUTION/GEN/NR0/575/10/IMG/NR057510.pdf?OpenElement Emphasis in original.

${ }^{104}$ Henri J. Barkey, Reluctant Neighbor: Turkey's Role in the Middle East (Washington, D.C.: United States Institute of Peace Press, 1996).
} 
opportunities as well as challenges as the Cold War paradigm based upon fierce rivalry between the Iron Curtain and the Western World crumbled. Non-involvement in the Iraqi invasion of Kuwait in Turkey's backyard might mean that Turkey was letting other major players in the region do whatever they wanted to do without any Turkish participation. The point of view would further push Turkey away from any possible role of re-shaping the post-Cold War world in surrounding areas. Second, the Turkish political establishment has pegged Turkey's strategic and political outlook to the West, primarily to the United States during the Cold War. The secular nature of the Turkish republic did not share some of the "values" of Arab nations. Ideational associations with Middle Eastern countries or their presumed "values", according to the Kemalist elite, could be seen as anathema to the very idea of the "progressive" and "western" aspects of the Turkish republic. Many in the Turkish political elite saw Arab nations as "back-stabbers" as they alluded to the assertion that Arabs had betrayed the Ottoman state by giving in the nationalism and caused the Ottomans to lose the Middle East during the World War I. ${ }^{105}$ Therefore, involvement in Middle Eastern affairs, for the Turkish elite, could be dangerous for Turkey. Related to this perspective, many in the Middle East perceived Turkish activism in the region as a revival of the pan-Ottomanism that aroused suspicion of Turkish imperialism. Third, many Arab nations were either siding with Soviets or nonaligned countries. Thus, Turkey did not want to jeopardize its status in the western flank by engaging with the Middle Eastern nations. The invasion of Kuwait by Iraq in 1990, however, did not allow Turkey to be impartial in the matter. Both the international

\footnotetext{
${ }^{105}$ Meliha Altunisik, Türkiye Ve Ortadoğu: Tarih, Kimlik, Güvenlik (Ankara: Boyut Kitaplari, 1999).
} 
community and the western world, especially the United States, were quick to react to the invasion. Non-involvement in the conflict next door was not an option for Turkey. However, the level of engagement in this affair has been one of the most contentious debates in the contemporary Turkish politics in early $1990 .{ }^{106}$ Even after that, Turkey's level of engagement with a special reference to the Gulf War was fiercely discussed among the Turkish political elite prior to the Iraqi War of 2003.

Escalating crises in Turkey's southern neighborhood left the Turkish government with three important questions regarding its policy implications. These questions, as laid out by William Hale, were "first, whether it would send troops to join the coalition forces in the Gulf; second, whether it would open a second front against Iraq along the IraqiTurkish border, if war broke out; whether it would allow the coalition powers (principally the United States) to use Incirlik for attacks on targets in northern Iraq, given that this was not strictly within the base's NATO functions."107

President Turgut Ozal understood that answering yes to all these questions would maintain Turkey's "western vocation" and show that Turkey was a reliable ally for the West in the face of an emerging, complex web of conflicts after the post-Cold War era. Hesitation towards these policies would likely reveal doubts among western European nations and the United States on the "strategic value" of Turkey with regard to facing challenges in the Middle East. He also thought that non-involvement in the Gulf conflict would leave Turkey on the sideline when other major regional and global powers were about to re-shape political configuration of the Middle East. Instead, activist Turkish

\footnotetext{
${ }^{106}$ For a discussion of Turkey's crisis on handling the Gulf War, see Mahmut B. Aykan, Turkiye'nin Kuveyt Krizi (1990-91) Politikası (Ankara: Dis Politika Enstitusu Yayinlari, 1998).

${ }^{107}$ Hale, Turkish Foreign Policy, 1774-2000., p. 220
} 
engagement, for him, would place Turkey into the center of the game. ${ }^{108}$ Furthermore, he knew that any arrangement about Iraqi Kurdistan on the political level without Turkish participation would cause a huge existential problem for Turkey as a result of its own Kurdish problem at home. His activist foreign policy orientation, however, faced swift resistance from opposition leaders such as Suleyman Demirel of the True Path Party (TPP) (Dogru Yol Partisi) and Erdal Inonu of the Social Democrat People's Party (SDPP) (Sosyal Demokrat Halkci Partisi). ${ }^{109}$ Some high ranking military officers like the Chief of General Staff Necdet Torumtay and senior diplomats in the Ministry of Foreign Affairs disagreed with President Ozal in a subsequently-published memoir. ${ }^{110}$ They were particularly unhappy about "his single handed approach to the government, especially on diplomacy, such as declaring his policy agenda without consulting senior diplomats or generals," 111 who were considered to be the prime decision makers on foreign affairs for a long period. Ozal wanted to assert a civilian mandate against the bureaucratic elite both in the military and the foreign affairs ministry and clearly criticized Turkey's traditional status quo-oriented foreign policy by saying that "my conviction is that Turkey should leave its former passive and hesitant policies and engage in an active foreign policy."112

The course change in Turkish foreign policy could not be understood only in terms of changes in the international system; domestic elements such as President Ozal's

\footnotetext{
${ }^{108}$ Hulki Cevizoglu, Körfez Savaşı Ve Özal Diplomasisi (Form Yayinlari, 1991).

${ }^{109}$ Hale, Turkish Foreign Policy, 1774-2000.

${ }^{110}$ Necip Torumtay, Orgeneral Torumtay'in Anilari (Istanbul: Milliyet Yayinlari, 1993).

${ }^{111}$ Hale, Turkish Foreign Policy, 1774-2000.

${ }^{112}$ Philip Robins, Turkey and the Middle East (London: Pinter Publishers, 1991)., p. 70
} 
leadership and his worldview also were factors. ${ }^{113}$ He became the prime minister in 1983 after three years of military rule following the 1980 coup. Ozal was educated in the United States and seemed to grasp ideas of a free market economy, entrepreneurship, democracy, secularism, and even politics, with a markedly American accent. His admiration of the U.S., in part, came from his conviction that what made the U.S. a success story was its aspiration toward liberal democracy and a market economy. As indicated by Berdal Aral, "Ozal persistently emphasized three fundamental freedoms in his speeches: freedom of expression, freedom of religion, and freedom of enterprise. Although such emphasis on classical freedoms seems too superficial in human rights debates, its significance in the Turkish context should not be underestimated, given that these freedoms had never been transformed into reality, despite the contrary proclamations of the Turkish constitutions and statutes." ${ }^{\not 14}$

He clearly saw the impending role of the sole superpower, the U.S., and wanted to have Turkey aligned with the U.S. in economic, political and strategic spheres. ${ }^{115} \mathrm{He}$ thought that Turkish engagement with the U.S. had always been strategic to Turkey, a relationships that he aspired to expand to other areas such as the economy. His motto of "trade, not aid" best signified his approach to extensive business dealings with the U.S., including his goal of having Turkey engaging with the U.S. on equitable terms. With his

\footnotetext{
${ }^{113}$ See divergent perspectives on Ozal and his policies. Hasan Cemal, Özal Hikayesi (Yenisehir, Ankara: Bilgi Yayinevi, 1989).; Heper and Sayari, Political Leaders and Democracy in Turkey.; Laciner, "Turgut Özal Period in Turkish Foreign Policy: Özalism."; Ihsan and Ihsan Dagi Sezal, Kim Bu Özal?: Siyaset, Iktisat, Zihniyet (Ankara: Boyut Kitaplari, 2001).; Orhan Tokatli, Kırmızı Plakalar: Türkiye'nin Özal'lı Ylllarl (Istanbul: Dogan Kitap, 1999).; Yalcin, The Özal: Bir Davanın Öyküsü.; Aral, "Dispensing with Tradition? Turkish Politics and International Society During the Özal Decade, 1983-93."

${ }^{114}$ Aral, "Dispensing with Tradition? Turkish Politics and International Society During the Özal Decade, 1983-93.", p. 74

${ }^{115}$ Gozen, Amerikan Kiskacinda Dis Politika: Korfez Savasi, Turgut Ozal Ve Sonrasi.
} 
new motto in mind, he tried to shift the Turkish mindset that relations with the U.S. would entail hierarchical dealings that favored the United States' interests and concerns while trumping the Turkish ones. ${ }^{116}$ Rather, he developed a strategy of engagement with the United States that saw the relationship in an egalitarian manner with added selfconfidence. The way he conducted his relations with his counterpart in the U.S., George H. W. Bush, was new, and exuded confidence to the Turkish populace. As Berdal Aral argued, his worldview made him indispensible ally for the United States due to his unique role in the heart of the Middle East, in which major crises were about to erupt. Turgut Ozal clearly saw the emerging new international milieu that the Soviet threat was no longer present. Instead new threats could be at the forefront of this environment like Islamic radicalism. He, however, rejected the idea that Islam and western world would collide with each other. Ozal advocated the idea that Muslim world can and should work with the western world, and supported the idea that Muslims needed to integrate into the world system that is primarily dominated by the West, especially the United States. He did not see any contradiction between one's deeply held Islamic beliefs and the western values. Rather, he saw that the close association with the West would provide benefits of modern science, technology and sustained economic growth. Therefore, he deeply disagreed with the premise of an Islamic union, and thought that it is "unnecessary and impractical." 117

\footnotetext{
${ }^{116}$ There are some in the academia disagreeing with the idea of Ozal's reformist foreign policy orientation. Rather, they say, his foreign policy orientation was in fact in line with traditional Turkish foreign policy making such as Turkish involvement in the Gulf War. See Aykan, "Turkey's Policy in Northern Iraq, 199195.", and Armaoglu, Belgelerle Turk-Amerikan Munasebetleri.

${ }^{117}$ Ibid. p. $75-76$
} 
He continued his premiership until 1989 when President Evren's term ended. He was elected as the eight President of Turkey by the Turkish Grand National Assembly (TGNA) with the support of his Motherland Party (MP) (Anavatan Partisi or ANAP in Turkish), which he had established in 1983 after the military coup. Even though the presidency was a highly ceremonial post, he preferred it as it enabled him to exert more civilian control in Turkish politics. Therefore, he handpicked Yildirim Akbulut as the prime minister. His main motivation was to control the two most important civilian posts in Turkey. His extensive involvement in the Gulf War on the side of the United States showed that he was not satisfied with his highly ceremonial post, but he wanted to administer the direction of the country by both holding the presidency and guiding the prime minister along his own agenda. The Turkish Presidency had been generally held by military leaders like Ataturk, Inonu, and Evren. Ozal became the second civilian president after Celal Bayar, who held the highest office in Turkey between 1950 and 1960.

On August 6, the UN adopted Security Council Resolution 661 urging the international community to implement international sanctions against Iraq in response to its noncompliance with previous resolutions demanding Iraq's withdrawal from Kuwait. The next day, Turkey declared its compliance with the resolution against Iraq, ended all business dealings, and closed the Yumurtalik-Kirkuk oil pipeline. The decision clearly indicated that Turkey was siding with the international community, specifically with the United States. However, this was not made with ease. As indicated earlier, opposition parties and other elements in the Turkish elite charged the government with reckless actions and argued that Ozal's enthusiastic support for the American cause was pushing 
Turkey into uncharted territory. Therefore, they urged Ozal to use caution and restraint, taking into account the fact that Saddam Hussein might attack Turkey as a result of its siding with the U.S. in countering Iraq. ${ }^{118}$ In early August and the following months, Turkey repeatedly requested Rapid Deployment Force from NATO in case of an immediate attack from Iraq because of Turkey's participation in the war efforts. By early January 1991, some in European countries such as Germany, Belgium and Italy stated that they would send military aircrafts to Turkey; yet, those shipped were outdated and sparked outrage in Turgut Ozal. ${ }^{119}$ On the positive side, the United States, France and Britain saw the legitimacy of Turkish concerns and sent military jets and stationed Patriot missiles on the Incirlik airbase, a leading front against Saddam's Iraq in organizing war efforts from the north. This move somewhat satisfied Turkish concerns of a possible Iraqi attack against Turkey and maintained the idea that NATO, at least the leading members, would protect Turkey in case of an attack from the outside. By the end of February 1991, the coalition forces' efforts in winning the war against Saddam Hussein and the liberation of Kuwait proved successful. However, the Bush administration did not go further in toppling Saddam Hussein from power, which Turgut Ozal had wholeheartedly advocated for from the beginning.

After the removal of Iraqi forces from Kuwait, President Bush urged "Iraqi people to take matters into their own hands" ${ }^{120}$ to depose Saddam. However, Saddam's legacy and power did not allow Kurds and Shiites to rise up to topple him. Both Barzani and

\footnotetext{
${ }^{118}$ William Hale, "Turkey, the Middle East and the Gulf Crisis," International Affairs 68, no. 4 (1992).

${ }^{119}$ Robins, Suits and Uniforms: Turkish Foreign Policy since the Cold War.

${ }^{120}$ Lokman I. Meho, The Kurdish Question in U.S. Foreign Policy : A Documentary Sourcebook, Documentary Reference Collections. (Westport, Conn.: Praeger, 2004).
} 
Talabani appealed to the U.S., but the Bush administration did not intervene as a result of strategic calculations: That such a move might involve a large scale U.S. involvement in the northern Iraq, which would not be popular in U.S. domestic politics. It could have also triggered the disintegration of Iraq and eventual destabilization of the Middle East. ${ }^{121}$ This would consequently endanger strategic U.S. interests in the region. Engagement with Kurds in Iraq would also deeply impact U.S. relations with Turkey, Iran and Syria. Long-term commitment and supporting Kurds would increase Turks' suspicions that the U.S. was supporting the establishment of Kurdistan that supposedly included southeastern Turkey. Any such signal would alarm Turkey and eventually break its bonds with the U.S. in the Middle East. The U.S. thus could not ignore the suffering of Kurds in Iraq, the sensitivities of Turkey in particular, or the importance of regional stability.

With the passage of the UNSC Resolution 687, the international community welcomed "the restoration to Kuwait of its sovereignty, independence and territorial integrity and the return of its legitimate Government" 122 and affirmed "the commitment of all Member States to the sovereignty, territorial integrity and political independence of Kuwait and Iraq." ${ }^{123}$ This was a reason for celebration for both Turkey and the United States. They had eliminated a major enemy and taught a lesson to Saddam on respecting the status quo and sovereignty of other nations in the Middle East. However, the jubilation for Turkey ended swiftly. Even though the war ended with the Kuwaiti

\footnotetext{
${ }^{121}$ Ibid.

${ }^{122}$ http://www.casi.org.uk/info/undocs/gopher/s91/4 (Accessed November 12, 2010)

${ }^{123}$ Ibid
} 
liberation, one major problem for Turkey and the United States immediately emerged. It was a large and sudden influx of Kurdish refugees from northern Iraq escaping into Turkey as they fled possible retribution from Saddam Hussein. ${ }^{124}$ The first wave of Iraqi Kurds were seen on the Turkish border in late March 1991, and, according to Mustafa Aydin, "it presented Turkey both a refugee problem of unprecedented proportions and a political problem, since the sensibility of its own Kurdish question for Turkey made it of far-reaching importance, thus left Turkey with an immediate dilemma... The main reason for Turkey's initial reluctance to permit large numbers of Iraqi Kurds to enter the country was the fragile situation on the Turkish side of the border. It was feared that an influx of Iraqi Kurdish refugees in Turkey for an undetermined time period might have a radicalizing effect on Turkish Kurds. Moreover, security problems were presented by the possibility of infiltration by the PKK guerillas into Turkey with refugees." ${ }^{125}$ It was, however, not new, given that Turkey encountered the same problem on a smaller scale in the late 1980s when Iraqi Kurds were targeted by Saddam Hussein after they supported Iran with its war with Iraq. Many Kurdish villages in the northern Iraq were burned and Kurds were forced to flee to Turkey to save their lives. Robert Olson indicated that " $[\mathrm{b}] \mathrm{y}$ 1987-88, it is probable that more than 1,000 Kurdish villages were destroyed; some estimates range as high as 4,000. Some sources estimate that by early 1988 up to onethird of the population of Iraqi Kurdistan had been depopulated. After the ceasefire with Iran in August 1988, 60,000 to 70,000 Iraqi troops attacked Kurds they thought had been

\footnotetext{
${ }^{124}$ Robert Olson, "The Kurdish Question in the Aftermath of the Gulf War: Geopolitical and Geostrategic Changes in the Middle East," Third World Quarterly 13, no. 3 (1992).

${ }^{125}$ Mustafa Aydın, Turkish Foreign Policy During the Gulf War of 1990-1991 (Cairo, Egypt: American University in Cairo Press, 1998)., p. 50-52
} 
loyal to Iran in the war and forced another 100,000 Kurds to flee to Turkey; 40,000 of whom were fleeing from Halabja, a small town in northeastern Iraq near the Iranian border, where they had been attacked with chemical gas by Iraqi forces during the middle of March." ${ }^{126}$ In fact, the Kurdish refugee problem at this time proved very costly for Turkey in both economic and political terms because many refugees stayed permanently, increasing the country's economic burden and making it more difficult and complicated for Turkey to deal with its Kurdish problem.

Facing Twin Problems: the de facto Kurdish State in the Neighborhood and Kurdish Insurgency at Home

The post-Gulf War environment posed serious problems for Turkey. First, Turkey did not want to see a repetition of the series of 1987 events when as many as 100,000 Iraqi Kurds fled from northern Iraq to southeastern Turkey to save their lives from atrocities inflicted by Saddam Hussein. Second, Turkey did not want to see the establishment of a Kurdish state in northern Iraq, which had a sizable Kurdish population that might aspire to do the same thing in southeastern Turkey and eventually establishing a Kurdistan that encompassed parts of Iraq, Syria, Iran and Turkey. Third, Turkey would not want to see the recurrence of a political vacuum after the Gulf War as was the case during the Iran-Iraq war. In the mid-1980s, a political vacuum in northern Iraq was filled by a PKK insurgency that caused considerable military and political damage to

\footnotetext{
${ }^{126}$ Olson, "The Kurdish Question in the Aftermath of the Gulf War: Geopolitical and Geostrategic Changes in the Middle East.", p. 477
} 
Turkey. ${ }^{127}$ In fact, this was one of the two red-lines for the Turkish establishment, who saw separatism ${ }^{128}$ and backwardism (religious extremism) as anathema to Turkey. The PKK insurgency would benefit from a lack of order in northern Iraq; therefore, it was crucial for Turkey to have Iraq's authority on its northern region, which was populated by Kurds.

Once it became clear that the U.S. would not intervene in Iraq to protect Kurds, nearly 1.5 million Kurds flooded into the borders of Turkey and Iran to escape Saddam's wrath. The sheer size of fleeing Iraqi Kurds posed one of the most daunting challenges for the Turkish administration. It was in no way comparable to the one Turkey experienced in 1988. Adding insult to injury, the western media showed the desperation of Kurdish refugees on the mountain passes near Turkish-Iraqi border, who were not allowed into Turkey. ${ }^{129}$ They depicted the Turkish administration as violating human rights by not allowing fleeing Kurds into its side of the border. Ozal faced a very difficult dilemma: either to see continuing western press coverage on the conditions of Kurdish refugees, which defamed the Turkish governments' image in the international public opinion, or tolerating the political, economic and social consequences of entry of more than one million Kurdish refugees into Turkey.

\footnotetext{
${ }^{127}$ For a review of the Kurdish insurgency and the PKK terrorism in Turkey, see Ismet G. Imset, $P k k$ : Ayrılıkçı Şiddetin 20 Yllı, 1973-1992 (Ankara: Turkish Daily News Yayinlari, 1993).

${ }^{128}$ Turkey's "Kurdish question" has been one of the most daunting challenges throughout the republican era especially since the mid-1980s. See varying Turkish perspectives on the subject. Hasan Cemal, Kurtler (Istanbul: Dogan Kitap, 2003).; Murat Belge, Türkler Ve Kürtler, Nereden Nereye? (Ankara: Birikim Yayinlari, 1995).; Rusen Cakir, Türkiye'nin Kürt Sorunu (Ankara: Metis, 2004).; Metin Sever, Kürt Sorunu: Aydınlarımız Ne Düşünüyor (Ankara: Cem Yayinevi, 1992).; Şengün and Mehtap Yücel Kılıç, Murat İnceoğlu, Biz Ve Onlar: Türkiye'de Etnik Ayrımcıllk : Araştırma-Röportaj (Ankara: Metis 1992).; Eric J. Zurcher, Imparatorluktan Cumhuriyete Türkiye'de Etnik Çatışma (Istanbul: Iletisim, 2005).

${ }^{129}$ Robert W. Olson, The Kurdish Nationalist Movement in the 1990s: Its Impact on Turkey and the Middle East (Lexington, KY: University Press of Kentucky, 1996).
} 
The United States adopted a new approach, choosing not to intervene in Iraq militarily to protect Kurds, but helping to pass UNSC Resolution 688 on April 5, 1991, which denounced Saddam's repression of Iraqi Kurds and asked Iraq to stop the persecution of Kurds. With the help of allies in western Europe (particularly the United Kingdom and France), and of Turkey, the U.S. instituted "Operation Provide Comfort" (OPC), a host of measures to protect Kurds in northern Iraq from Saddam Hussein. The initiative under UNSC Resolution 688's premise of protecting Kurds brought a no-flyzone for Iraqi aircrafts in the north of $36^{\text {th }}$ parallel that was enforced by the U.S., the U.K., and France. There would also be small ground forces based in Silopi, Turkey to provide humanitarian relief for Kurds. Many in Turkey believed that OPC was creating a huge vacuum of authority, which was filled by PKK, the terrorist organization launching deadly attacks in Turkey from northern Iraq. They also thought that the creation of the OPC was paving the way for the establishment of Kurdistan at the expense of the Turkish Republic, ${ }^{130}$ reminding them painfully of the Treaty of Sèvres of 1920 that partitioned the decaying Ottoman state among its multi-ethnic minorities and the Allied powers. What is dubbed the "Sèvres Syndrome" in the Turkish lexicon has been rampant throughout the 1990s. It was basically a conviction that Turkey was surrounded by enemies that aimed to divide it up according to their "historical" claims. This psyche, however, was not limited to enemies. It has also developed a habit of cynically perceiving its allies on the same premise. For example, Turkey has long aspired to be part of the European Union, then the European Community, and developed deep-rooted economic and political relations to that continent during the Cold War. However, Europe's increasing critique of Turkey's

\footnotetext{
${ }^{130}$ Oran, Kalkık Horoz: Cekic Guc Ve Kurt Devleti.
} 
human rights violations against Kurds in the late 1980s and the1990s roused se Turkey's suspicions of European support for Kurdistan. Therefore, any critique of the Kurdish issue or hint of western support for Kurdish causes alarmed the Turkish elite. In the same vein, any U.S. involvement in Kurdish entities in the northern Iraq provoked the Sèvres Syndrome not only among Turkish populace but the Turkish elite, who were deeply indoctrinated in the ideas of Turkish national sovereignty, unitary government, and territorial integrity. Given that the PKK's extensive operational capability caused enormous damage in blood and treasure reinforced a widespread conviction that the West, including the United States, was supporting the establishment of an independent Kurdistan. ${ }^{131}$ Regardless of statements made by the senior U.S. officials, many in Turkey saw the U.S. committed to the establishment of Kurdistan. ${ }^{132}$

At this crucial juncture, President Ozal heeded the UNSC Resolution to establish "safe heavens" in northern Iraq and provide security by the coalition forces against possible Saddam-backed attacks towards Kurds. The unconventional and resourceful idea of creating "safe havens" in northern Iraq had both its opportunities and challenges for Turkey. The establishment of "safe havens" in northern Iraq seemed less threatening than an influx of Kurdish refugees into Turkey in the minds of the Turkish political elite. Nevertheless, the idea of "safe havens" opened the door for an autonomous Kurdish entity next door. There was a potential that this entity could grow into an independent state, which Turkey had vehemently opposed. By the end of April 1991, 17,000 coalition troops started "Operation Provide Comfort", which had a mandate from the UN to

\footnotetext{
${ }^{131}$ Turan Yavuz, Abd'nin Kürt Kartı (Istanbul: Milliyet Yayinlari, 1993).

${ }^{132}$ Ibid.
} 
establish a security zone in north of $36^{\text {th }}$ parallel in Iraq. ${ }^{133}$ Most of the Kurdish refugees returned to "safe havens" in northern Iraq by June with security provided by OPC presence. Suffering heavily from the western media's unfavorable coverage on Kurdish refugees, the orderly return of refugees provided breathing room for the Turkish leadership. Turgut Ozal was credited for his creative and unconventional approach to the solution. However, he received his fair share of criticism from the Turkish media on the possible side effects of "safe havens" in leading up to an independent Kurdish state. In July 1991, "Operation Provide Comfort" was succeeded by "Operation Poised Hammer" with the mission of preventing Saddam Hussein from attacking Kurds in the region. However, the mission of the operation garnered great suspicion among the Turkish public as well as the Turkish intelligentsia, who argued that it would eventually lead to the creation of the independent Kurdistan. Some even argued that Turkish involvement in the mission might drag Turkey into conflicts with neighboring nations. ${ }^{134}$

The post-Gulf war environment provided one of the most convenient opportunities for Kurds to establish their long-awaited state or at least to have autonomous governance in northern Iraq. ${ }^{135}$ However, there were major obstacles to this dream. All surrounding nations, Iraq, Iran, Syria and Turkey clearly saw any move towards autonomy for Kurds as a zero-sum game, resulting in loss of territories in those nations. Moreover, any such move would jeopardize the internal status quo of those

\footnotetext{
${ }^{133}$ UNSC Resoution 688 provided a legal base for a "no-fly-zone" in the north of $36^{\text {th }}$ parallel. This was mainly to protect Kurds from Saddam Hussein's retribution.

${ }^{134}$ Sever, Kürt Sorunu: Aydınlarımız Ne Düşünüyor.

${ }^{135}$ Olson, "The Kurdish Question in the Aftermath of the Gulf War: Geopolitical and Geostrategic Changes in the Middle East.", p. 497
} 
surrounding nations and might lead to territorial disintegration, given that each had sizable Kurdish minorities in their soils. Specifically Turkey, as mentioned earlier, was mindful of this reality, and very sensitive to any such claims of establishing a Kurdish state. To head this off, Turkey took some serious measures to contain any such aspirations by Kurdish minorities in northern Iraq.

During the Cold War, the U.S. did not support Kurdish causes and even ignored human rights violations against Kurds in Turkey. It was obvious that the Cold War security environment and U.S. security calculations had always focused on the larger picture, which was to contain and defeat Soviet expansionism. Any issue of repression of minorities would not be considered as high politics because the highest priority was to preserve close alliances like that with Turkey. ${ }^{136}$ In the mid-1980s, the State Department issued reports on human rights violations of Kurds by the Turkish state as it countered PKK activities. However, these reports had no major consequences in shifting Turkey's treatment of its own Kurdish citizens. For Turkey, dealing with the PKK insurgency could be done through heavy-handed military measures in the mid-1980s and early 1990s. Keep in mind that Turkey had military rule from 1980 to 1983 , and that the military's role in Turkish politics was overwhelming even when Turgut Ozal as the prime minister was trying to liberalize the politico-economic system to reduce generals' role on the key political issues. As Turgut Ozal was to reform Turkey, he thought that the Turkish political elite, mainly the military and civilian bureaucracy, had false senses of domestic threats to Turkish republicanism and its territorial integrity. These elites

\footnotetext{
${ }^{136}$ Kemal and Gareth M. Winrow and Ahmet Fethi Kirişçi, Kürt Sorunu: Kökeni Ve Gelişimi (Istanbul: Turkiye Ekonomik ve Toplumsal Tarih Vakfi, 1997).
} 
believed that rising religious observance and its increasing manifestations on the public sphere, and Kurdish minority's requests for cultural rights, were existential threats to secular Turkey. As Aral put it, Ozal thought otherwise: Turgut Ozal understood that Turkey's deliberate distance to its past, namely to the heritage of the Ottoman Empire was artificial, and it was also an impediment to strong and influential Turkey. He thought that Turkey would eventually come to terms with its past that he saw as example of tolerance and pluralism. Additionally, he contended that Turkey would not be a successful country unless it would solve its major domestic problems, namely the exclusion of non-Turkish identities, and marginalization of Islamic influences. Therefore, he vigorously worked on the elimination of these impediments in order to foster a nonideological state that would accommodate both non-Turkish minorities and Islamic manifestations in Turkish society. ${ }^{137}$

Ozal himself understood that Turkey's strict policy on the Kurdish question both at home and abroad was not sustainable. Being an observant Muslim himself and halfKurdish, he thought that Turkey's domestic Kurdish issue had links with its foreign policy choices regarding the situation in northern Iraq. His unorthodox policy of promoting "safe havens" in northern Iraq for Kurdish refugees led to another opening in dealing with the Kurdish tribal entities in northern Iraq: directly talking to Massoud Barzani, the leader of the Kurdistan Democratic Party (KDP) or (Partiya Demokrata Kurdistanê in Kurdish) and Jalal Talabani, the leader of Patriotic Union of Kurdistan (PUK) or (Yekîtîya Nîş̧timanîya Kurdistan in Kurdish). Up to that point, Ankara

\footnotetext{
${ }^{137}$ Aral, "Dispensing with Tradition? Turkish Politics and International Society During the Özal Decade, 1983-93.", p. 74-75
} 
consistently avoided directly talking to or even contacting them, believing that any such move would give "legitimacy" to these "tribal chiefs" and might encourage them to pursue their autonomy from Iraq more persistently. ${ }^{138}$ However, Ozal believed otherwise. He thought "the importance of differentiating Kurdish discontent in Turkey from that of Iraqi Kurds" ${ }^{139}$ Moreover, engaging with Kurdish groups in northern Iraq would give leverage to Turkey to isolate the PKK in northern Iraq and thereby limiting its attacks and political activities in southeastern Turkey. By mid-March of 1991, both Barzani and Talabani came to Turkey incognito and had discussions with senior bureaucrats in the foreign affairs ministry. ${ }^{140}$ It should be noted that this unprecedented shift in Turkish policy towards Kurdish groups in Iraq could directly be attributed to the Ozal's initiative in handling de facto emerging Kurdish authority in northern Iraq. It is obvious that both leaders of opposition parties, Suleyman Demirel of TPP and Erdal Inonu of SDPP, were outraged by the Ozal's directive of meeting with Kurdish leaders. They raised the concern that this was a clear departure from the Kemalist tradition of non-interference with the domestic affairs of another country. However, their main contention was that Turkey was now directly dealing with Barzani and Talabani, who, they thought, did not represent the Iraqi government, but gave "legitimate representation" to Kurds. However,

\footnotetext{
${ }^{138}$ Aydın, Turkish Foreign Policy During the Gulf War of 1990-1991.

${ }^{139}$ Ibid., p. 61

${ }^{140} \mathrm{Ibid}$
} 
many scholars on Turkey believed that the Ozal's move was bold and correct in dealing with the challenges of post-Gulf War environment and its own Kurdish problem. ${ }^{141}$

Prior to the Gulf War, Turkey was importing nearly $60 \%$ of oil from northern Iraq. Ozal foresaw the significance of Iraq especially after the post-war environment. To a certain degree, his "activism" in the Gulf War affairs could be attributed to his calculations that Turkey needed to position itself to exert greater influence in accessing oil in northern Iraq. He also wanted to counterbalance Iran's influence because of the large Shi'ites population in Iraq, had Saddam be removed from power after the U.S. intervention. Gesturing to Iraqi Kurds, he wanted to improve relations with them. As some analysts suggested, his presumed support for enhanced Kurdish autonomy in Iraq, in turn, generated the policy that Iraqi Kurds refrained from supporting PKK activities in the region. Given that the PKK terrorist activities significantly increased in Turkey in early 1990s, having Iraqi Kurds siding with Turkey was in fact a success because Ozal's policy in northern Iraq achieved the separation between the PKK leadership and Iraqi Kurdish factions. ${ }^{142}$

Ozal also sought to ease Turkey's own Kurdish problem by proactively talking about it and taking measures such as repealing the ban on Kurdish language. He promised more cultural rights overall, such as Kurdish broadcasting rights, though this was not possible until 2009, when JDP government successfully implemented the Kurdish TV

\footnotetext{
${ }^{141}$ See Henri J. Barkey and Graham E. Fuller, Turkey's Kurdish Question (Lanham, Md.: Rowman \& Littlefield Publishers, 1998).; Kramer, A Changing Turkey: The Challenge to Europe and the United States.; Taspinar, Kurdish Nationalism and Political Islam in Turkey: Kemalist Identity in Transition.; Çandar, "The Kurdish Question: The Reasons and Fortunes of the 'Opening'."; Heper and Sayari, Political Leaders and Democracy in Turkey.; Laciner, "Turgut Özal Period in Turkish Foreign Policy: Özalism."; Hale, "Turkey, the Middle East and the Gulf Crisis."

${ }^{142}$ Aydın, Turkish Foreign Policy During the Gulf War of 1990-1991. , p.63
} 
initiative by establishing TRT 6, a state-owned channel under the Turkish Radio and Television (TRT). Though Ozal's reforms in providing cultural rights to Kurds in Turkey seemed limited, the era in which he proposed them made them revolutionary in nature. ${ }^{143}$ No one among the Turkish political elite, it seems, had the courage and the vision of extending rights to Turkey's Kurdish minority, given that the Turkish establishment saw it as putting dynamite to the foundation of Turkey's territorial integrity. It should, of course, be noted that Turkey's rising civil society, Kurdish minority and conservative segments of Turkish society were supportive of Ozal's reforms since they represented the periphery of the Turkish nation that were often repressed or kept away from the political center. Employing rhetoric and actions that promoted individual rights and the promise of more inclusive politics, Ozal was able to attract the support of these masses. ${ }^{144}$

However, the influence of Ozal on the Turkish parliament and the government was severely hampered when the governing Motherland Party lost the election on October 20, 1991. The new coalition government formed by the TPP's Suleyman Demirel and the SDPP's Erdal Inonu spelled the start of a new era in Turkish politics. The question of whether Turkey's new leaders would follow Ozal's initiative of engagement with Iraqi Kurds and his activist foreign policy with the United States was raised. Interestingly enough, both Demirel and Inonu who opposed Ozal policies regarding Iraq and Kurds when they were opposition leaders, shifted their rhetoric and policies regarding the engagement with Barzani and Talabani forces in northern Iraq. As Prime Minister Demirel said after ascending to the power, “...the people in the southeast

\footnotetext{
${ }^{143}$ Sezal, Kim Bu Özal?: Siyaset, Iktisat, Zihniyet.

${ }^{144}$ Laciner, "Turgut Özal Period in Turkish Foreign Policy: Özalism."
} 
are our brothers, the people in the northern Iraq are their brothers and ought to be our brothers too. ... Turkey was just a bystander in the past when faced with events in northern Iraq. For instance, there was the Halabje incident. We said 'that's outside our frontiers, it's nothing to do with us.' This policy ought to change. Turkey's new policy should be as follows: if Baghdad commits another barbarity in northern Iraq, it will find us opposing it." ${ }^{145}$ It clearly showed that the policies Ozal once instituted were now the main staples of Turkey’s Kurdish policy. Demirel, who had once fervently criticized Ozal on his policy of engagement with Iraqi Kurds and the implementation of the OPC, became the prime supporter of these policies. However, Turkey, as hinted at above, entered into a new era of weak and inefficient coalition governments throughout the 1990s and early 2000s. ${ }^{146}$ What is popularly dubbed the "lost decade" of the '90s (with the start of Demirel-Inonu coalition government) paralyzed Turkish politics and its economy, faltering under eleven different governments in a decade. ${ }^{147}$ Managing the relations with Iraqi Kurds, the United States, Iraq, Iran, Syria, Greece, the EU as well as the growing role of the military on Turkish politics and society, once again proved a daunting task for those coalition governments. Therefore, fluctuations in policy

\footnotetext{
145 "Turkey's New Kurdish Policy," Milliyet December 10, 1991. Cited in Aydın, Turkish Foreign Policy During the Gulf War of 1990-1991., p. 65

${ }^{146}$ For the discussions on Turkey's turbulent political atmosphere in 1990s, see Cavdar, Turkiye'nin Demokrasi Tarihi.; Yucel, Türkiye'nin Siyasal Partileri: 1859-2006.; Cavdar, Türkiye'nin Demokrasi Tarihi:1950'den Günümüze.; Feroz Ahmad, Demokrasi Surecinde Turkiye (1945-1980), trans. Ahmet Fethi (Istanbul: Hil Yayinlari, 1994);; Karpat, Turk Demokrasi Tarihi - Siyasal, Ekonomik, Kulturel Temeller.; Barry M. Rubin and Metin Heper, Political Parties in Turkey (London ; Portland, OR: Frank Cass, 2002).

${ }^{147}$ No single coalition government in 1990s survives no more than two years. Some even ended within the two months of taking the office. This instability in Turkish governments had long-lasting impact on Turkish politics and economy especially economic crises of 1994 and 2001, and political crises of 1993, 1997, and 2002.
} 
orientation occurred according to the political forces dominant in Turkish politics. In reference to aforementioned point, specifically on government's handling of Kurdish issue, a major shift on Turkey's handling of the Kurdish problem occurred in 1993. As Philip Robins puts it, "[t]he critical development in this change of attitude in Ankara was the Faustian pact between the newly installed prime minister, Tansu Ciller, and the chief of the general staff, Dogan Gures. In order to consolidate her grip on government, Ciller believed that she needed to neutralize the military as a political force. She did so extremely successfully by ceding to the armed forces virtually complete control over policy towards the Kurdish issue, while she concentrated on the rest of the national policy agenda. Ciller consequently proved to be even less willing than reticent predecessor Demirel to meet the Iraqi Kurdish leadership, effective political consultations coming to an end with Barzani's visit to Ankara in June 1993." ${ }^{148}$ The shift of transferring political authority over Kurdish policy to the military indicated that Ozal's civil and liberal initiative on the Kurdish issue both at home and in northern Iraq was partially abandoned in favor of heavy-handed military measures. Ciller's main motive at the time, as indicated by Phillip Robins, was to consolidate her weak power on domestic affairs so that she could create more breathing room for herself on challenging issues. However, this plan did not provide the desired outcome. Instead, Turkish politics was heavily consumed with political instability, economic turmoil, and the prospect of military intervention. Many in the Turkish political elite considered 1993 to have had an unannounced military coup. ${ }^{149}$

\footnotetext{
${ }^{148}$ Robins, Suits and Uniforms: Turkish Foreign Policy since the Cold War., p. 329

${ }^{149}$ Even though there was no actual declaration of military intervention but the visibility of military on political matters became more obvious in 1993.
} 
It is also important to note that some mysterious and dangerous events in 1993 were unfolding, which signaled some significant discomfort among some influential circles in the Turkish establishment, especially in the military. Obviously, the main source of friction was the Kurdish question. The leading journalist Ugur Mumcu was assassinated on January 24, 1993. He was known for his investigative reports and it was believed that he was at the time working on a possible link between the PKK terrorist organization and Turkey's intelligence unit known as Milli Istihbarat Teskilati (the National Intelligence Organization). ${ }^{150}$ Esref Bitlis, the commander of the Turkish Gendarmerie died in a mysterious plane crash on February 17, 1993. Some blamed the United States, arguing that he had opposed the OPC activities in the northern Iraq on the assumption that Americans were helping to create an independent Kurdish state, asserting that he had some "evidence" of Americans delivering arms to Talabani and Barzani concealed in food crates. ${ }^{151}$ Adding insult to injury and darkening the political atmosphere, President Turgut Ozal, who had faced Turkey's Kurdish issue by implementing impressive reforms, passed away on April 17, 1993 due to a heart attack- but many, including his wife, Semra Ozal, believed that he was poisoned. ${ }^{152}$ To this day suspicions about the deaths of these three individuals continue, and many in Turkish society still believe they were eliminated because of their deep involvement in the Kurdish issue. As one could

\footnotetext{
${ }^{150}$ Nese Duzel, "Mumcu, Apo'nun Devletteki Baglantisi Buldu (Mumcu Found State's Connection with Apo)," Radikal 29 May 2005. However, no hard evidence was discovered about the link despite the fact that the suspicion of Turkey's state organizations' involvement with the PKK was still alive to this date.

${ }^{151}$ Hasim Soylemez, "Esref Bitlis Ile Cem Ersever'i Ayni Ekip Oldurdu (Esref Bitlis and Cem Ersever Were Both Killed by the Same Team)," Aksiyon 11 August 2008.

${ }^{152}$ Nese Duzel, Taraf 24 November 2008.
} 
imagine, these deaths brought significant suspicion to the Turkish political system and its foreign policy objectives regarding the Iraqi Kurds and the United States role.

Implications of the Kurdish Problem for the Turkey-U.S. Relations

Both Barzani and Talabani wanted to have an independent Kurdistan from the beginning. It suffices to say that a close look at the history of Kurdish revolts in Iraq would confirm such ambitions. However, great powers in the Middle East (the UK in the $19^{\text {th }}$ century and the first half of the $20^{\text {th }}$ century, and the U.S. in the second half of the $20^{\text {th }}$ century) were not trusted fully on the premise of independent Kurdistan. For example, Massoud Barzani developed distrust of the U.S. government given that his father passed away in exile in the U.S. under poor conditions in the mid-1970s. He believed that the U.S. has given priority to its own interests regarding the suffering of Kurdish people in Iraq. The cynicism and sense of betrayal have always been in the mind of Barzani and he did not totally trust that Kurds in northern Iraq would get statehood with the support of the United States. Even though the post-Gulf War configuration of the Middle East presented the most suitable condition for statehood since World War I, he understood that the United States could not promise and fully support Kurds in attaining statehood. Such a move would alarm Turkey, a crucial ally that the United States could not afford to lose, especially in light of the U.S. having lost Iran, its closest ally in the Middle East at the time, to the Islamic revolution in 1979. The Turkish suspicion of the OPC's "hidden agenda" of establishing Kurdistan proved that Turks were vigilant and would use any means necessary to avert such actions. It could easily be argued that the OPC could be credited for the creation of a functioning de facto Kurdish state and government in northern Iraq. On the other hand, it should be noted that it also gave 
Turkey the military capability to launch incursions into the Kurdish region of the northern Iraq to curb PKK sanctuaries. It is really intriguing to see that Turks wanted to eliminate PKK forces by cross-border operations in the Iraqi Kurdish regions but caused collateral damage among Talabani's Kurdish factions, thus enraging Talabani and eventually damaging their cooperation on removing or at least limiting the PKK's activities. "The U.S. also faced enormous task of juggling on several contradicting tasks: protecting Kurds from Saddam, letting Turkey for cross-border operations in northern Iraq, and but facing with a growing Turkish perception that the U.S. aimed at establishing independent Kurdistan." 153

The prominent scholar on Turkish politics, William Hale, claimed that Ozal's enthusiastic support for the U.S. mission in the Gulf War was to re-assert Turkey's strategic importance in the eyes of the West, especially the United States. He wanted to demonstrate to westerners that Turkey was still relevant, and that strategically positioned in the emerging security schemes of the post-Cold War environment. He easily captured the U.S. support by exerting more Turkish control in Operation Provide Comfort, and by presenting Turkey as a possible candidate for counterbalancing Iran's influence in the region. ${ }^{154}$ As a bottom line, Ozal successfully navigated Turkey in this uncharted territory of the newly-emerging international system. He saw the opening of a new era of unchallenged American leadership and wanted to situate Turkey closer to it. His wholehearted and often-times single handed support for the Gulf War on the side of the United States was a clear indication of this conviction. He also advanced the rights of the

\footnotetext{
${ }^{153}$ Hale, Turkish Foreign Policy, 1774-2000., p. 222

${ }^{154}$ Ibid.
} 
Kurdish minority and of Turkey's observant Muslims amid fierce opposition from the ardent Kemalist establishment. Extending more rights to Turkish citizens and limiting military tutelage in Turkish politics gave way to a vibrant civil society and growing middle class that emerged not from Istanbul but from Anatolian cities such as Kayseri, Konya, Gaziantep and Adana. Once considered the exclusive realm of the military and foreign affairs bureaucracy, Turkish people enjoyed growing influence on their state's foreign policy-making. Thus, accountability and public opinion, to a certain degree, entered into Turkish politics, especially on issues of foreign policy. As Ozal and other successive leaders learned, keeping the status quo of Iraq and of the Middle East intact has been the main goal of Turkey in the post-Gulf War environment. However, this came at a cost: permitting the establishment of a semi-autonomous Kurdish authority in the northern Iraq and facing growing economic costs from the UN sanctions against Iraq. When all these costs are noted, however, ensuring that Turkey would be among the Western political and security structures in this emerging world order was paramount to Turkey. Last but not least, Ozal wanted to eventually see Turkish entry into the European Community with the support of NATO members, especially the United States. The episode of turmoil and dynamic changes both in the international system and Turkish society brought a host of new challenges and opportunities for Turkey and defined the very nature of evolving Turkish-American relations in the post-Cold War era. 
CHAPTER IV: TOWARDS STRATEGIC PARTNERSHIP, 1994 - 2000

The Gulf War and its strong Turkish involvement, as discussed in previous chapters, became a defining factor in Ankara's relations with Washington. It left a lasting impact on the identification and redefinition of Turkey's domestic and foreign affairs, especially with the United States. The Kurdish question both at home and in the neighborhood continued to be one of the top agenda items for Turkey throughout the 1990s. The increasing intensity of PKK attacks in Turkey, coupled with the ever-pressing reality of an autonomous Kurdish authority despite the in-fighting among the Kurdish factions in northern Iraq, resulted in more aggressive Turkish measures, especially from the military. Some of Turkey's anti-PKK actions in southeastern Turkey led to widespread human rights violations among Turkey's Kurdish citizens. The United States and European nations repeatedly cautioned Turkey on its treatment of Kurds, thereby straining their relationship with Turkey. While the U.S.'s strategic outlook on Turkey always trumped concerns like human rights violations, Europeans conversely pressed Turkey harder. They were bolstered by their proximity to Turkey, a vibrant Kurdish diaspora in Europe, and the EU's commitment on human rights issues. Since the mid1990s, Turkey's domestic affairs became messier. Weak coalition governments could not produce stability in economy and politics and thereby incited a greater role of the Turkish military in Turkish politics. In addition to instability in domestic affairs, Turkey's relations with Greece and Syria were severely strained and both came close to the brink of war with Turkey. On the other hand, the rapprochement between Turkey and Israel, and passionate U.S. support for Turkey's bid for European Union membership, resulted in a new phase in the Turkish-American relations: strategic partnership. In Chapter IV, 
the question of how and to what extent the dynamic interaction of Turkey's domestic and foreign affairs challenges between 1994 and 2000 had implications on Ankara and Washington will be addressed.

\section{Disappointments and Prospect for Engagement}

Mounting challenges like dealing with PKK terrorist attacks and Turkey's

Kurdish problem received widespread attention and triggered discussions on the question of how to solve them. ${ }^{155}$ One major analysis of the Turkish government showed that Kurds in southeastern Turkey were left impoverished and faced severe economic difficulty. Economic issues were the root causes of the discord among Kurds and therefore for PKK support. ${ }^{156}$ If measures in economic development and greater cultural rights were to be taken, the logic went, the Kurdish question could largely be diminished, if not solved. For this purpose, President Demirel launched the Southeastern Anatolian Project (Guneydogu Anadolu Projesi, GAP) in November 1994. ${ }^{157}$ The GAP was a large network of irrigation projects and 22 hydroelectric dams that would be constructed in the basins of the Euphrates and Tigris rivers. It was intended to create massive irrigated

\footnotetext{
${ }^{155}$ See James Brown, "The Turkish Imbroglio: Its Kurds," Annals of the American Academy of Political and Social Science, no. 541 (1995).; Kemal Kirisci and Gareth M. Winrow, The Kurdish Question and Turkey : An Example of a Trans-State Ethnic Conflict (London ; Portland, Or.: Frank Cass, 1997).; Taspinar, Kurdish Nationalism and Political Islam in Turkey: Kemalist Identity in Transition.; Metin Heper, The State and Kurds in Turkey: The Question of Assimilation (Houndmills, Basingstoke, Hampshire ; New York: Palgrave Macmillan, 2007).; Olson, "The Kurdish Question in the Aftermath of the Gulf War: Geopolitical and Geostrategic Changes in the Middle East."; Philip Robins, "The Overlord State: Turkish Policy and the Kurdish Issue," International Affairs 69, no. 4 (1993).; Abramowitz, Turkey's Transformation and American Policy.

${ }^{156}$ For a discussion of the economic cost of the PKK terrorism, see the report "Terörün Ekonomik Maliyeti: Diyarbakır Olayları Örneği," (Ankara: USAK, 2010).

${ }^{157}$ The idea of the GAP project was initiated by Turgut Ozal as he was trying to address grievances of Kurdish citizens in the areas of cultural and political rights and economic development. See the extensive coverage of Turkish media on the launch of the GAP, "Guneydogu Sorununa Gap Cozumu," Milliyet November 10, 1994.; Hurriyet November 10, 1994; Sabah November 10, 1994.
} 
farming areas where predominantly Kurdish populations would benefit economically while satisfying the Turkish economy's growing needs for energy from the dams.

Turkey's delicate engagements with Iraq's Kurdish factions and the U.S.'s balancing acts in the region became increasingly difficult in the mid-1990s with the unsettling impact of the post-Gulf War environment. ${ }^{158}$ In mid-1994, two Iraqi factions, Barzani's Kurdistan Democratic Party and Talabani's Patriotic Union of Kurdistan, engaged in a civil war, putting both Turkey and the U.S. in a very difficult position. Turkey could no longer rely on Barzani to remove or at least restrict the PKK from safe havens in northern Iraq. On March 20, 1995, Turkey took matters into its own hands and sent 35,000 troops to northern Iraq to combat the PKK terrorists. The U.S. Deputy Secretary of State Richard Holbrooke supported the Turkish incursion in northern Iraq and said Turkey's security was connected to that of Europe; therefore, Turkey's action was justifiable. ${ }^{159}$ Turkish Prime Minister Tansu Ciller visited the United States in April 2005 and had extensive talks with President Clinton. The top agenda items were the situation in Iraq and PKK terrorism. ${ }^{160}$ The in-fighting between Kurdish factions also made the U.S. task of protecting Kurds difficult. The situation was only helpful to regional rivals of Turkey and the U.S., namely Iran, Syria, and Iraq (Saddam Hussein). Iran and Syria opposed extensive U.S. engagement in regional politics and wanted to derail the U.S.-imposed settlements among Kurdish factions. Saddam opposed the

\footnotetext{
${ }^{158}$ See Turkey's Kurdish challenges in 1990s in Turkish resources. Gencer and Sule Kut Ozcan, En Uzun on Yıl: Turkiye'nin Ulusal Guvenlik Ve Dis Politika Gundeminde Doksanlı Yıllar (Istanbul: Boyut Kitapları, 1998).; Cakir, Türkiye'nin Kürt Sorunu.; Altunisik, Türkiye Ve Ortadoğu: Tarih, Kimlik, Güvenlik.; Cemal, Kurtler.

${ }^{159}$ Yasemin Congar, "Abd, Pkk’ya Artik Farkli Bakiyor," Milliyet April 10, 1995.

${ }^{160}$ The discussions also included bilateral political and economic issues between Ankara and Washington. See Sukru Elekdag, "Abd, Turkiye'yi Neden Destekliyor," Milliyet April 30, 1995.
} 
Turkish and the U.S. engagements in Iraq for obvious reasons. The Clinton administration wanted to end this civil war and did so by inviting the two warring parties to Dublin, Ireland in August 1995. Turkey was invited as an observer and Turkish concerns for the PKK's cross-border attacks were addressed by the presumed KDP's measures along the border to prevent PKK incursions in Turkish soils. The in-fighting ended with a cease-fire between the KDP and the PUK in the fall of 1996. As Ofra Bengio observed, Turkey played a significant role in brokering a cease-fire in October 1996 between warring factions in Iraq. The main motivation for Turkey was to situate itself as mediator so that it could influence the decision making process and, to a certain degree, control the direction of northern Iraq. According to Bengio, Turkish government had three objectives: "keeping the two parties under Turkish control, minimizing the involvement of other local and regional players in the issue, and most important of all, employing the two parties against the Turkish Kurdish Party and the [PKK], which established its base in Iraqi Kurdistan... It was indeed the PKK threat that dictated Turkish involvement in the Iraqi Kurdish issue, not only through military incursions into Iraqi Kurdistan but also through the alliances Turkey formed with the local Kurdish players." ${ }^{161}$ Interestingly, Turkey named its conflict resolution efforts between the PUK and the KDP as the "Ankara peace process," markedly stamping Turkish influence and desires. On the other hand, the U.S. also tried to mediate between the Kurdish factions, and especially worried that the PUK could be siding with Iran, and that the KDP could be inching toward Baghdad.

\footnotetext{
${ }^{161}$ Ofra Bengio and Gencer Özcan, "Old Grievances, New Fears: Arab Perceptions of Turkey and Its Alignment with Israel," Middle Eastern Studies 37, no. 2 (2001)., p. 385-6.
} 
In May 1997, Turkey started another massive incursion called "Operation Hammer" with 50,000 troops entering northern Iraq to curb the PKK presence and consolidate KDP strength against the PKK. Turkey for the first time did not retreat after the incursion, leaving a sizable force to control the border. Talabani saw this as a reinforcement of Turkish-Barzani cooperation and so it almost severed his relationship further with Barzani. The PUK attack against the KDP areas provoked Turkish anger and brought heavy Turkish involvement (Operation Dawn) on the side of the KDP in removing PUK from KDP areas in September and October 1997. Despite repeated ceasefires, in-fighting continued between the KDP and the PUK through the next year. On July 18, 1998, David Welch, from the State Department responsible for Near Eastern affairs, led a U.S. delegation in northern Iraq, inviting warring Kurdish parties and the Turkish delegation to mend their differences. After a series of meetings, Talabani and Barzani were invited to Washington in September 1998. Before the two leaders met in Washington for the first time since 1994, they separately stopped in Ankara to discuss Turkey's relations with their respective parties. After long and heated meetings in Washington, Talabani and Barzani reached a tentative agreement, the "Washington Accord," as Secretary of State Madeline Albright announced. ${ }^{162}$ "The U.S.-brokered accord calls for the rival Iraqi Kurdish factions to begin revenue sharing, reestablish a united legislature abandoned in 1992, unify their militias, and hold parliamentary

\footnotetext{
${ }^{162}$ Michael M. Gunter, "United States Foreign Policy toward the Kurds," in The Kurdish Question in U.S. Foreign Policy: A Documentary Sourcebook, ed. Lokman I. Meho (Praeger Publishers, 2004)., p. 25
} 
elections by July." 163 According to Alan Makovsky, "[t]here are at least three positive factors that suggest that stability can endure in the region even if the agreement is not implemented. One is the fact that the Kurdish leaders are talking to one another again. Second of all, the Kurds perceive the U.S. to have reinvigorated its commitment to the Kurds, to protect them against attack by Saddam as a result of this agreement. Thirdly, there is more money in the area now, including in the PUK areas thanks to UN Security Council oil-for-food resolutions. So, even without the transfer of funds from the KDP, the PUK areas are doing much better. The analyst cites Turkey's acceptance of the Washington accord as a fourth influence for stability. Ankara, which is fighting Kurdish rebels of its own, accepted the accord after Washington and London affirmed their commitment to Iraq's territorial integrity. The Iraqi Kurdish factions also assured Turkey they will deny the Kurdistan Workers Party (PKK) any bases in northern Iraq. Turkey has frequently carried out military operations in northern Iraq, in alliance with the KDP, to attack PKK bases." ${ }^{164}$ On other hand, the Washington Accord did not live up to its premise of repairing relations between the KDP and the PUK. As Michael Gunter argued, ${ }^{165}$ in spite of the hype behind the Washington Accord, only the cease-fire had sustained. Other ambitions decisions such as revenue sharing, creating a joint KDP-PUK government and administering elections could not be realized by the deadline. Even though the U.S. government made attempts to resolve the differences by inviting the KDP and the PUK to the Higher Coordination Committee, power struggle between

\footnotetext{
${ }^{163}$ Charles Recknagel and Sa'ad Abdul Qadir, "Iraq: Washington Seeks to Strengthen Kurdish Accord " (Radio Free Europe Radio Liberty RFE/RL, January 09, 1999).

${ }^{164}$ Ibid

${ }^{165}$ Gunter, "United States Foreign Policy toward the Kurds.", p. 9
} 
warring Kurdish factions and regional powers prevented the implementation of the Washington Accord.

The Washington Accord took the initiative from Turkey to resolve the conflict between warring Kurdish factions. Turkey's "Ankara peace process" initiative was supplanted by the Accord even though if it had satisfied many of Turkey's concerns in the document, such as keeping Iraqi territory intact and limiting the PKK's offensive against Turkish targets. ${ }^{166}$

Turkey's push for curbing PKK terrorism and eliminating safe havens for the group's leader, Abdullah Ocalan, became increasingly aggressive. ${ }^{167}$ In October 1998, Turkey threatened Syria with military action in retaliation for its providing sanctuary for Ocalan and for not heeding repeated Turkish warnings on closing terrorist training camps in Syria and Lebanon. To show its resolve, Turkey sent more than 10,000 troops to the Syrian border. Understanding the serious nature of Turkey's show of force, Syria agreed to close down the training camps and eventually forced Abdullah Ocalan to leave Syria. According to the reports, "[s]ince October [1998], Mr. Ocalan had been on the run - from Syria to Italy to Russia to Greece. He finally landed in the Greek Embassy in Nairobi, Kenya, on Feb. 2." ${ }^{168}$ American intelligence officers helped capture Abdullah Ocalan, who caused the death of more than 37, 000 people from 1984 to $1999 .{ }^{169}$ He was delivered to Turkish commandoes in Nairobi, Kenya on February 15, 1999. He was tried

\footnotetext{
${ }^{166}$ Ferai Tinc, "Türkiye'nin Kuzey Irak Politikası Nedir? ," Hurriyet October 2, 1998.

${ }^{167}$ Michael M. Gunter, "The Continuing Kurdish Problem in Turkey after Ocalan's Capture," Third World Quarterly 21, no. 5 (2000).

${ }^{168}$ Tim Weiner, "U.S. Helped Turkey Find and Capture Kurd Rebel," New York Times February 20, 1999. ${ }^{169}$ Ibid.
} 
and sentenced to death. However, the death penalty was abolished due to Turkish compliance of the Copenhagen Criteria to enter in the EU, and thus his sentence commuted to life in prison without the possibility of parole. It was obvious that both political and public sentiments in Turkey were against the commutation. ${ }^{170}$ The U.S. help in detaining Ocalan was well-received by the Turkish government and improved the Turkish public's perception of the U.S., which had long suffered from suspicions about U.S. intentions for the creation of an independent Kurdish state in northern Iraq. ${ }^{171}$ Apart from the determining role of the post-Gulf War environment and the Kurdish question in the region, some other regional issues also influenced and redefined Ankara and Washington's interactions in the 1990s. For example, Turkey's relations with Greece had always been contentious between Ankara and Washington. As a result of the sizable and influential Greek diaspora community in the U.S., some adverse actions were taken against Turkey by the U.S. Congress, which was understandably susceptible to pressure from Greek-Americans. For example, in August 1994, the U.S. House of Representatives approved the foreign aid bill that included a military aid package with a $10 \%$ cut to Turkey. The cut was conditional upon the improvement of human rights and

\footnotetext{
${ }^{170}$ Ironically enough, nationalist parties in the coalition government passed a legislation that banned the death penalty after the capture of Ocalan. Many in the Turkish media argued that this was a clear indication of unmatched Turkish desires to enter the EU and finish off the PKK terrorism. However, others rumored that the U.S. delivered Abdullah Ocalan to the hands of Turkey with a condition that he would not be put to death. See the discussions in Turkish newspapers, Hasan Pulur, "Eger Ceza Yasasi Degistirilebilseydi," Milliyet July 1, 1999.; Radikal February 14, 2001; Hurriyet February 11, 2001.

${ }^{171}$ However, there seemed to be some divergent opinions on the presumed U.S. intention to deliver Ocalan to Turkey. Deputy Undersecretary of Turkey's National Intelligence Institution (MIT) at the time Cevat Ones later argued that Ocalan was an impediment to the U.S. aspirations for an independent Kurdish state in the region. Therefore, he was captured by the CIA and delivered to Turkey since he was no longer useful to the supposed U.S. plan. See "Abd Apo'yu Teslim Etti Çünkü Bağımsız Kürt Devletine Engeldi (America Delivered Ocalan Because He Was an Impediment to Independent Kurdish State)," Vatan October 15, 2008.
} 
progress on the Cyprus issue, both of which touched a nerve in Turkey. The Turkish government rejected the conditional part of the deal. As Marcia Christoff Kurop pointed out in her Foreign Affairs article, "[t]heir long standing hostility, marked by mutual suspicion and distrust, is of more than parochial concern given the strategic importance of the region, lying at the crossroads of the Middle East, Central Asia, and Europe. Compared with Greece's past regional controversies, its disputes with Turkey are more vast and complicated - political problems in essence, but overwhelmed by historical bad blood, incessant second-guessing of motives, and high-pitched rhetoric that plays well in each side's press. These two countries, for all their past intermingling and cross-cultural ties, are simply different animals, psychologically and politically." ${ }^{172}$ Proving her point in terms of defining the nature of Greek-Turkish relations in the 1990s was the danger of war with Greece in late 1995. When a Turkish cargo ship ran ashore on the uninhabited islets called Imia (or Kardak in Turkish) in the Aegean Sea in December 1995, both Turkey and Greece claimed that they were their islets. A tiny islet with an estimated area of 10 acres brought two rivals to the brink of war. ${ }^{173}$ President Clinton called on both Turkish and Greek leaders to stop the escalation and start discussions on long-standing issues between Turkey and Greece, including the Cyprus issue and maritime problems in the Aegean Sea. Richard Hollbrooke successfully negotiated with the two parties to

\footnotetext{
${ }^{172}$ Marcia Christpff Kurop, "Greece and Turkey: Can They Mend Fences?," Foreign Affairs 77, no. 1 (1998)., p. 7

${ }^{173}$ Both Greek and Turkish populations were eager to go to war against each other. A survey of Turkish newspapers between December 26, 1995 and January 30, 1996 showed a fervent political environment regarding the threat of war. See Hurriyet, Milliyet, Sabah, Zaman and Cumhuriyet dailies. "Clinton'in Ege Endisesi," Milliyet January 29, 1996.; Nazim Alpman, "Bizim De Bir Falkland'imiz Oldu " Milliyet January 29, 1996. See also Kostas Ifantis Mustafa Aydin, ed., Turkish-Greek Relations: Escaping from the Security Dilemma in the Aegean (London: Routledge, 2004).
} 
withdraw from Imia/Kardak islets. ${ }^{174}$ However, this did not fully solve the conflict between Greece and Turkey. In fact, Ocalan, as indicated earlier, was captured in the Greek Embassy in Nairobi in 1999, a situation that demonstrates Greek enmity towards Turkey. Harboring the "head of terrorists," 175 namely Abdullah Ocalan, caused heightened tension between two countries, both of which were NATO members but considered each other enemies. For the United States, such degrees of enmity and the possibility of war between Athens and Ankara could threaten the stability of the region and might jeopardize vital U.S. interests in keeping the NATO alliance intact. Clinton's intervention in the Kardak crisis could explain why the U.S. administration saw the possibility of massive instability in the region. One also needed to remember the Cyprus crisis in the 1960s and the Turkish invasion of the island in the 1970s to recall the bad blood between Greece and Turkey.

One of the high marks of the 1990s in the relationship between Ankara and Washington was the U.S.'s unwavering support for the Turkish bid for European Union membership. The United States saw Turkey as a "bulwark" at the southeastern flank of NATO against Soviet threats during the Cold War and considered it an indispensible ally in the Gulf War. The successive U.S. administrations supported the idea that Turkey's closer relations with European nations would serve vital U.S. interests. The basic premise was that keeping Turkey in the western flank would be a source of stability and prosperity. It also reinforced the idea that Turkey's push for democratization and reforms,

\footnotetext{
${ }^{174}$ Mustafa Aydin, ed., Turkish-Greek Relations: Escaping from the Security Dilemma in the Aegean.

${ }^{175}$ The term "Terrorist Basi" in Turkish (the head of terrorists) to refer to the PKK leader Abdullah Ocalan was widely used in Turkish media and public.
} 
despite its poor human rights records at the time, indicated its enduring will to enter into the exclusive European club. Additionally, Turkey's unmatched geopolitical position and its unique identity as a Muslim majority nation, being both democratic and secular at the same time, could coincide with American engagement in the region. It would also serve as a "model" for other Muslim nations in which Washington had significant vested interests ranging from access to energy resources to the security of Israel, a strategic U.S. ally. From the Turkish view, EU membership would be the culmination of its "western vocation" that was shown as the "contemporary level of civilization" by its founding father, Ataturk. Many among the Turkish elite thought that Turkish modernization and westernization since 1923 would culminate and be considered complete with EU membership. Therefore, fulfilling the Copenhagen Criteria for entry into the EU was widely accepted by both the Turkish political elite and the populace. ${ }^{176}$ One such development occurred when the European Parliament signed the Customs Union agreement with Turkey on December 13, 1995, enabling goods and services to be exchanged between Turkey and the EU without any custom duties as of January 1996. Initially, Europeans were reluctant to include Turkey, but the Clinton administration successfully lobbied on behalf of Ankara in European capitals. The U.S. support for the Customs Union was duly noted by Turkey as another sign of "enhanced partnership" with the U.S. despite the engagement in Iraq. Yet, Turkey's accession process did not go smoothly. On December 12, 1997, Turkey was excluded from the next wave of European enlargement at the Luxemburg Summit of the European Council even though the Union

\footnotetext{
${ }^{176}$ Hüsamettin Inaç, Avrupa Birligi'ne Entegrasyon Sürecinde Türkiye'nin Kimlik Problemleri (Ankara: Adres Yayinlari, 2005).
} 
accepted all other applicant countries for accession negotiations. ${ }^{177}$ "The Luxembourg summit provoked a wave of outrage in Turkey and prompted it to freeze its political dialogue with the EU. Most Turks believed that the Luxembourg decision was taken due to religious and cultural factors. This impression was fuelled by a statement of the European Christian Democratic Union that 'the EU is in the process of building a civilization in which Turkey has no place.' Other concerns were of a more political nature, such as German anxiety over Turkish immigrant workers, and French and Italian reservations over Turkish exports of textiles and agricultural products. However, these concerns usually remained obscured by the official rhetoric that focused on the 'Greek veto', human rights and a lack of democratization." ${ }^{\prime 178}$ Angered by the EU's decision, the U.S. sought a more aggressive role in acquiring Turkish candidacy status for EU membership at the Helsinki Summit in December 1999. President Clinton personally called European leaders and State Department officials lobbied hard for Turkey's EU bid. The work paid off when Turkey attained candidate status for EU membership, reversing the Luxembourg Summit's decision. It should be noted that this decision was made by the Europeans in part due to the Clinton administration's pressure. Other major support for Turkish membership was provided by the Bush administration. Sabri Sayari indicated that "prior to the EU summit meeting in Copenhagen in December 12, 2002, the U.S. once again launched a major campaign to advance Turkey's prospects for entry into the EU. When President Bush met the leader of the Justice and Development Party, Tayyip

\footnotetext{
${ }^{177}$ Meltem Müftüler-Baç, "The Never-Ending Story: Turkey and the European Union," Middle Eastern Studies 34, no. 4 (1998).

178 "Turkey's Quest for Eu Membership," in EU Briefings (European Union Center of North Carolina, 2000)., p. 2
} 
Erdoğan, at the White House on December 11, he reaffirmed Washington's support for Turkey and declared that the U.S. 'stands side by side with Ankara in its bid to join the European Union." ${ }^{\prime 179}$ It could easily be argued that the U.S. support for Turkey's membership for the EU had been more enthusiastic than it was for many other European nations. The U.S. even received considerable criticisms from European leaders who argued that the U.S. was meddling into the EU's business. ${ }^{180}$ As Sabri Sayari laid out, there were significant disagreements between the U.S. and the EU on the idea of Turkey's membership. The United States as an emerging sole superpower recognized that Turkey was an important country in the region despite the fact that Europeans did not appreciate Turkey's unique position. Washington believed that Turkey could be an asset in countering conflicts in the intersecting regions of the Middle East, the Balkans, and the Caucasus. However, Europeans rather focuses on non-traditional security threats like illegal immigration, drug trafficking, asylum seekers and environmental problems. Therefore, the European impression of Turkey was less favorable than the United States, and the EU did not share the strategic value attached to Turkey by Washington. For example, the U.S. saw Turkish bid for the EU accession as critical given that Turkey's unique identity as a secular, democratic and Muslim nation could resolve the issue of the "clash of civilizations." Anchoring Turkey to the west through the EU, for Washington, was the best bet that Turkey's pro-western orientation could be fully secured. However, the EU did not share the same sentiments given that Europeans worried about large influx

\footnotetext{
${ }^{179}$ Sabri Sayari, "The United States and Turkey's Membership in the European Union," in The Turkish Yearbook $(34,2003)$., p. 169

${ }^{180}$ Bruce Kuniholm, "Turkey's Accession to the European Union: Differences in European and Us Attitudes and Challenges for Turkey," Turkish Studies (Spring 2001).
} 
of migrant workers to European cities, and that large Turkish population would result in more seats in the European parliament and thereby more representation in the European affairs. Many European officials claimed that all the problems associated with the Turkish membership would be faced by Europeans not by the United States. ${ }^{181}$

It was obvious that the U.S. push for the Turkish membership caused considerable strain in transatlantic relations. Many in Europe saw the U.S. activism as an intrusion to its domestic affairs and expressly indicated that the decision should be left to Europeans. The prospect of Turkish membership in the EU has not been realized yet, but it was clear that the U.S. would support the Turkish bid, partially because Turkey's active engagement in Balkans, the Middle East, the Caucasus and the European Union in 2000s increased its strategic value to the transatlantic alliance. Regardless of the EU's shortsighted political hindrances, Turkey and the U.S. will seek EU membership until an outright rejection or inclusion is realized.

As Turkey's activist policies of the Gulf War on the side of the United States signaled a shift in the transformation of Turkish foreign policy orientation, another major Turkish initiative emerged: strengthening the relations with Israel in political, economic and strategic areas. ${ }^{182}$ Meliha Altinisik observed that " $[\mathrm{t}]$ he newest and at the same time the most controversial aspect of Turkish foreign policy in the post-Cold War Middle East

\footnotetext{
${ }^{181}$ Sayari, "The United States and Turkey's Membership in the European Union.", p. 172-174

${ }^{182}$ See relevant literature on Turkish-Israeli relations in the 1990s. M. Hakan Yavuz, "Turkish-Israeli Relations through the Lens of the Turkish Identity Debate," Journal of Palestine Studies 27, no. 1 (1997); Suha Bolukbasi, "Behind the Turkish-Israeli Alliance: A Turkish View," Journal of Palestine Studies 29, no. 1 (1999).; Kemal Kirisci Barry M. Rubin, Turkey in World Politics : An Emerging Multiregional Power (Boulder, Co.: Lynne Rienner Publishers, 2001).; Robert W. Olson, Turkey's Relations with Iran, Syria, Israel, and Russia, 1991-2000 : The Kurdish and Islamist Questions, Kurdish Studies Series (Costa Mesa, Calif.: Mazda Publishers, 2001).; Efrahim Inbar, "Regional Implications of the Israeli-Turkish Strategic Partnership," Middle East Review of International Affairs 5, no. 2 (Summer 2001).
} 
has been constantly developing Turkish-Israeli relations. In a relatively short period of time economic relations flourished between the two countries and culminated in the signing of a free trade agreement in 1996. Cultural and educational links accelerated at an unprecedented degree. Furthermore, and the most controversial of all, the two countries increased security cooperation within the framework of two agreements that were signed in 1996. This increasingly deep and open relationship between the two countries disturbed some of their neighbours in the region. It has been argued that growing ties between these two countries were steadily changing the regional balance of power." 183 The rapprochement and the defense cooperation in 1996 alarmed Arab nations in the region, as Bengio and Ozcan argued, "because it caught the Arab world at one of its weakest moments, in the aftermath of the fragmentation caused by the Gulf War, and because it was interpreted as being anti-Arab to the core. Hence, it's being termed an anti-Arab alliance. The fear, in fact, was fourfold: that the alignment would increase the strategic threat to the Arab countries in general and the more vulnerable ones - Syria and Iraq - in particular; that it would marginalize the Arab world in the international arena; that it would further fragment the Arab world by bringing to the alignment an Arab country - Jordan; and finally that it would jeopardize the Arab-Israeli peace process or at least weaken the Arab partners' bargaining power by providing Israel with new strategic depth, as it were, and thus strengthen its hand, as well as its intransigence at the negotiating table." ${ }^{184}$ Turkey's unique history with Israel since its establishment in 1948,

\footnotetext{
${ }^{183}$ Meliha Altunisik, "The Turkish-Israeli Rapprochement in the Post-Cold War Era," Middle Eastern Studies 36, no. 2 (April 2000)., p. 172

${ }^{184}$ Özcan, "Old Grievances, New Fears: Arab Perceptions of Turkey and Its Alignment with Israel.", p. 50
} 
and Turkey's formal recognition of Israel as a state the very next year, made IsraeliTurkish relations qualitatively different from those of other Middle Eastern nations. As a close ally of the U.S., and a NATO member, Turkey saw Israel favorably and considered it as useful a partner in both regional and international affairs. The Turkish political elite understood that enlisting Israel as a partner and an ally would strengthen its ties to the United States due to the influential role of the Jewish lobby in Washington. The alliance with Israel and therefore with the Jewish lobby could also counterbalance the negative influence of Greek and Armenian diasporas in curtailing Turkey-related issues in the U.S. government, including Congressional issues like the Armenian-Americans' push for the passage of a resolution on the Armenian genocide issue. Many in the Turkish elite continuously sought access to the Jewish lobby in the U.S. via Israel. ${ }^{185}$ In the same vein, the United States welcomed the rapprochement between Israel and Turkey and saw this as helpful to wider U.S. interests in the Middle East. The relationship between the two countries, according to the U.S. calculations, would provide more leverage in dealing with the regional rivals of Israel as the United States considered Israel's security and legitimacy part of its "vital national security interests" throughout the Cold War and its aftermath. The triangulation of the U.S., Turkey and Israel relationship paved the way for a shift in the balance of power and to a certain degree successfully countered the policies of Iran, Syria and Iraq in the 1990s. As a first sign of the rapprochement, in December 1991 “Turkey upgraded its diplomatic relations with Israel, and as well as with the

\footnotetext{
${ }^{185}$ See Turkish perspectives, Gencer Ozcan, Türkiye-İsrail Ilişskilerinde Dönüşüm: Güvenliğin Ötesi (Istanbul: TESEV Yayinlari, 2005).; Mahmut B. Aykan, Soğuk Savaş Sonrası Dönemi Ortadoğu'sunda Türkiye'nin Ísrail'e Karşı Politikası, 1991-1998 (Istanbul: Yeditepe Universitesi, 2000).; Huseyin Aykol, Ortadoğu Denkleminde İsrail-Türkiye Ilişkileri (Oteki Yayinevi, 1998).; Cakmak, Turk Dis Politikası, 1919-2008.
} 
[Palestinian Liberation Organization] PLO, to ambassadorial level" ${ }^{\text {186 }}$ The rapid pace of economic cooperation, ever-increasing flow of Israeli tourists to Turkey and the Turkish military's aspiration to access to Israel's advanced military technology in the 1990s elevated Israeli-Turkish relations to an unprecedented level and dubbed them "strategic relations" by 1996. For instance, the volume of trade between Israel and Turkey was close to $\$ 100$ million in 1989 , but it reached to an astonishing $\$ 620$ million in 1997, a more than five-fold increase under eigtht years. ${ }^{187}$ Additionally, the Turkish military envisioned a modernization plan for the armament that would cost about $\$ 150$ billion in a period of two decades to bring up the army to task in countering possible conflicts in the region. ${ }^{188}$ As a result of Turkey's negative human rights records, western nations, especially European nations, were increasingly reluctant to provide military technology to Ankara. The U.S. State Department's references to human rights violations increased especially in the mid-1990s, hindering the approval of armament-related bills in the U.S. Congress. Therefore, Turkey's national security establishment saw Israel as an important partner because of Israel's advanced technology know-how and defense industry. "On 5 December 1996, they signed an agreement to modernize 54 of Turkey's F-4 Phantom aircraft for 650 million dollars. In 1997 Israel also won the tender for upgrading Turkey's F-5 aircraft. Israel and Turkey also agreed to produce the sophisticated Popeye II air-toground missile in a deal initially worth about $\$ 100$ million. Turkey had already bought 50 Popeye I missiles for its F-4 fighters. The deal involved a consortium with two Turkish

\footnotetext{
${ }^{186}$ Altunisik, "The Turkish-Israeli Rapprochement in the Post-Cold War Era.", p. 175

${ }^{187}$ Ibid. p. 176

${ }^{188}$ Ibid.
} 
firms to produce Popeye II, a smaller version with more advanced technology. In addition there were talks for deals for the modernization of tanks and other aircraft." ${ }^{189}$ One also should note that initial contacts in reviving the rapprochement were made by Turkish generals. Many in academia would agree that "[t]he principal ideologists of developing the relations with Israel on the Turkish part were the Undersecretary of the Foreign Ministry Onur Oymen and the Deputy Chief of the General Staff, Cevik Bir. According to them, the strategic menaces to the Turkish national security are different from those of the Cold War years which demands new approaches including the military-political cooperation with Israel, the sole secular state in the Middle East, adhering to the proWestern positions, Western values and democratic principles." 190

\section{Turkey's Domestic and foreign affairs intricately mingled: Israel and the United States}

The triangular engagements of Israel, Turkey and the United States in the 1990s truly reflected the changing dynamics of the Middle East as the United States asserted its newfound "sole-superpower" status by taming the excesses of Saddam's ambitions. Turkey claimed active involvement in the Middle East on the American side, in contrast to Turkey's long-preferred regional policy of non-involvement. Israel reinforced its regional standing and national security interests by enlisting Turkey as a Muslimmajority nation against its neighboring foes. The strategic calculations of these three nations throughout the 1990s were largely driven by their respective converging interests. However, the level of strategic partnership between Israel and Turkey did come at a cost.

\footnotetext{
${ }^{189}$ Ibid., p 187. See also a detailed account of the Turkish and Israeli defense cooperation in 1990s. Sergey Minasian, "The Turkish-Israeli Military and Political Co-Operation and Regional Security Issues," Iran \& the Caucasus 7, no. 1/2 (2003).

${ }^{190}$ Ibid. p. 311
} 
While deepening relations with Israel was a matter of foreign policymaking, the implications of this decision for Turkish domestic political affairs were intricate and dynamic. The domestic ramifications of Turkey's Israel orientation had far-reaching effects even in the case of Turkey's seriously strained relations in the years 2008 through 2011.

To grasp the multifaceted linkage of domestic and foreign affairs, one needs to look at Turkey's domestic landscape in mid 1990s. National identity has been a battleground for Turkey since its founding in 1923. Mustafa Kemal Ataturk founded Turkey on the premise of secular nationalism. While venerating Turkishness and secular western identity, the Turkish state marginalized non-Turkish minorities such as Kurds and religious Islamic masses. Islam was seen as an impediment to modernity and a bringer of economic backwardness. It was Islam, they argued, that left the Ottoman state backward and that was not compatible with its European counterparts. ${ }^{191}$ They also took note of the multi-ethnic nature of the Ottoman state and believed that the idea of a Turkish nation state on the premises of French Revolution and republicanism would fit the new Turkish state well. In a way, the new Turkey was an anti-thesis of what the Ottoman Empire was. Therefore, any close association with the Ottomans or their values was perceived as a threat to the Turkish republic. ${ }^{192}$ It is important to note that there were

\footnotetext{
${ }^{191}$ Falih Rifki Atay was one of the leading figures in early republican Turkey in discussing these ideas. He was a close friend of Ataturk. See Falih Rifki Atay, Cankaya (Istanbul: Yeni Gun Haber Ajansi, 1999).

${ }^{192}$ See discussions on the nexus between Turkish identity and the Ottoman past, Suavi Aydin, Amacimiz Devletin Bekasi: Demokratiklesme Sürecinde Devlet Ve Yurttaslar (Istanbul: TESEV, 2006).; Karpat, Turk Demokrasi Tarihi - Siyasal, Ekonomik, Kulturel Temeller.; Tanil and Kemal Can Bora, Devlet, Ocak, Dergah -12 Eylul'den 1990'lara Ulkucu Hareket (Istanbul: Iletisim Yayinlari, 2000).; Heper, The State and Kurds in Turkey: The Question of Assimilation.; Metin Heper, The State Tradition in Turkey (North Humberside: Eothen Press, 1985).
} 
four major Kurdish rebellions in Turkey from 1925 to 1937. It was no surprise that the PKK terrorism started in the early 1980s and that the Kurdish question has been a major domestic and foreign policy issue for Turkey since then. From 1923 to the 1980s, manifestations of Islamic beliefs and of non-Turkish identities were heavily suppressed. When Turgut Ozal was popularly elected in 1983, the Turkish state's ideological obsessions about non-Turkish identities and Islam began to thaw. Ozal took bold measures to liberalize the economy and provided opportunities to Anatolian entrepreneurs who generally held conservative values. The rise of these "Anatolian tigers $" 193$ and new emerging manufacturing centers in Anatolian cities such as Kayseri, Gaziantep and Konya began to challenge the primacy of the traditional business elite, which was largely represented by the Turkish Industrialists' and Businessmen's Association ( Turk Sanayicileri ve Isadamlari Dernegi, TUSIAD). ${ }^{194}$ Economic diversification and an increase in the visibility of religious conservatives in the Turkish economy and politics thus paved the way for more vibrant political demands and its manifestations, such as the ever-increasing number of private television stations, newspapers, magazines, educational institutions, trade unions, cultural institutions, religious foundations and political parties. Highly-educated youth who generally came

\footnotetext{
${ }^{193}$ This term refers to the phenomenon that Turkish entrepreneurs from Anatolian cities such as Kayseri, Gaziantep and Konya showed the impressive growth numbers since 1980s and redefined economic, political and cultural aspects of Turkey since then. "Anatolian tigers" challenged the hegemony of traditional political and business elite and helped shaped the direction of foreign affairs in Turkey's immediate neighborhood due in part to their extensive business dealings in Iraq, Syria and Russia. See a discussion on this, Thomas W. Smith, "Between Allah and Atatürk: Liberal Islam in Turkey," The International Journal of Human Rights 9, no. 3 (September 2005).

${ }^{194}$ TUSIAD is the prime business association largely represented by the traditional business elite, who had been benefitting from the government contracts and supports. The TUSIAD's business elite is in by and large staunchly secular and displeased the rise of "Anatolian tigers" that challenged the prominence of TUSIAD elite's in business.
} 
from unprivileged backgrounds began to hold positions not only in diverse business enterprises but in government. Interestingly, as Hakan Yavuz noted, "several decades of economic expansion and political liberalization have provided the grounds for the construction of an Islamic political identity. However, it is important to note that the current movement of Islamic identity is not a reversion to old ways but rather a 'modern creation, constructed in relation to current politics.' This form of Islamic identity is detached from its traditional rural environment and rooted in an urban, market driven context." ${ }^{195}$ The diversification of the elite and new discourses obviously brought new demands and power to the center, which had been largely occupied by the Kemalist establishment since the founding of the republic. Facing the risk of losing the hegemony that the establishment enjoyed for so many years, Kemalists accused the emerging elite of being an extension of Iran's "grand ambitions" to convert Turkey to an Islamic sharia state or directly associate them with Islamic backwardism. ${ }^{196}$ The fear among the Kemalists became very discernible when the political Islamist Welfare Party (WP) (Refah Partisi) ${ }^{197}$ won the elections on December 24, 1995 with $21.38 \%$ of the total votes cast. It was the first time that an Islamist party succeeded in general elections in Turkey. However, it took more than six month for Erbakan to get the official word from President Demirel to form a coalition government. Demirel had beforehand given the duty to form a government to the Motherland Party's Mesut Yilmaz, who came in second place in the

\footnotetext{
${ }^{195}$ Yavuz, "Turkish-Israeli Relations through the Lens of the Turkish Identity Debate.", p. 25

${ }^{196}$ Ilhan Selcuk, "Dincilerin Azgınlı̆̆ı," Cumhuriyet October 10, 2006.

${ }^{197}$ See ideas and the evolution of Islamism in Turkey, Ismail Kara, Turkiye'de Islamcilik Dusuncesi: Metinler, Kisiler (Istanbul: Risale, 1987).; Kazim Gulecyuz, Islam'da Siyaset Dusuncesi: Derleme (Insan Yayinlari, 1995).; Gencay Saylan, Turkiye'de Islamcl Siyaset (Ankara: Verso, 1992).
} 
election, even though doing so was against the Turkish state's established practices. The leader of the WP, Necmettin Erbakan, and Tansu Ciller of TPP formed a coalition government on June 28, 1996 in which Erbakan was the Prime Minister. Political Islamists' "capture" of the premiership, intense PKK attacks in Turkey, raging in-fighting among Kurdish factions in northern Iraq, Syria's support for the terrorist training camps in its soils, and charges and countercharges of spying with Iran deepened the sense of insecurity among the Kemalist establishment. Fervent critiques from Europeans and, to a certain degree, Americans, on Turkey's widespread human rights violations isolated Turkey further in the international arena. Lasting impacts of the April 5, 1994 economic crisis worsened the political prospect for stability at home as well. ${ }^{198}$ The weakness of coalition governments between 1991 and 1995, some argued, led in part to the rise of the Islamist Welfare Party, which was untried and therefore looked upon with hope by some segments of society, who looked to untested sources to drag Turkey out of its economic and political downward spiral. ${ }^{199}$ It could easily be argued that the period between 1995 and 1998 was one of the most difficult episodes in Turkish political history, in which domestic and foreign affairs intricately intermingled and posed deep challenges for Turkey and its future. Adding insult to injury, European officials wounded Turkish pride at the Luxemburg Summit in December 1997 when they refrained from including Turkey in the EU's next enlargement phase. This exacerbated the Kemalists' sense of isolation

\footnotetext{
${ }^{198}$ See debates on the causes of economic instability in Turkey, Erinc Yeldan, Kuresellesme Surecinde Turkiye Ekonomisi: Bolusum, Birikim Ve Buyume (Istanbul: Iletisim Yayınları, 2001)., Ziya and Rubin Önis, Barry M., The Turkish Economy in Crisis (London: Frank Cass, 2003).; Oktay Yenal, Cumhuriyet'in Iktisat Tarihi (Istanbul: Homer Kitabevi, 2003).; Gulten Kazgan, Tanzimattan 21. Yuzylla Turkiye Ekonomisi (Istanbul: Bilgi Universitesi Yayınları, 2002).;

${ }^{199}$ M. Hakan Yavuz, Islamic Political Identity in Turkey, Religion and Global Politics (New York: Oxford University Press, 2003).
} 
and insecurity, for they perceived the slight as evidence of Europe's rejection of Turkey because of its Muslim identity. In this context, one can easily see why both the Turkish political and military elite decided to upgrade Turkey's economic and security relations with Israel to the level of strategic cooperation in 1996. As indicated earlier, the Turkish military wanted to institute Israel as its strategic partner to quell isolation in the international arena, to show Europeans that Turkey had "secular credentials", to send a message to Syria, Iran and other Arab nations that it could counterbalance their strategic presence in the Middle East, and to get more leverage in Washington through Israel and the Jewish lobbies. ${ }^{200}$ "Affter the formation of Erbakan's coalition government in June 1996, yet another motivation was added: to embarrass the pro-Islamic government by exposing its powerlessness to halt an alliance it had openly opposed."201

Prior to his win in December 1995, Erbakan in his election campaign made some peculiar statements that were considered by many as anti-western, anti-American and anti-Israeli. For example, he wanted to withdraw from NATO, end military and political ties with Israel and halt the U.S. initiative of Operation Provide Comfort in northern Iraq. Instead of Turkey's western vocation, he sought to establish "Islamic" mirror images of institutions like the IMF, EU, NATO and G7 that would be populated exclusively by Muslim nations. ${ }^{202}$ "Erbakan's strategic aim was to turn Turkey into a leader in the

\footnotetext{
${ }^{200}$ Yavuz, "Turkish-Israeli Relations through the Lens of the Turkish Identity Debate."

${ }^{201}$ Ibid. p. 27

${ }^{202}$ Cumhuriyet February 26, 1998.
} 
Muslim world as opposed to a 'subservient follower' in the western bloc."203 Americans' anxiety and skepticism concerning Erbakan's fiery rhetoric ${ }^{204}$ was best captured by Morton Abramowitz, former U.S. ambassador to Turkey. He said, “[h]ow do you deal with a NATO ally led by a man who is fundamentally anti-NATO, fundamentally antiSemitic and fundamentally pro-Islamist, even when he's largely behaving himself." 205 In his first week in the office, Erbakan met with U.S. Undersecretary of State Peter Tarnoff on July 2, 1996, he said in the meeting that "as a first step to secure peace in the Middle East, [Israel] must withdraw from the territories it invaded, including the Golan Heights and that his government intended to form closer ties with all the brotherly Muslim countries in the region."206 Prime Minister Erbakan made his first official foreign visit to Iran in August 1996, broaching cooperation with a formidable enemy of Israel and the United States. His high-profile visit ended with an agreement of a \$20 billion deal for Turkey to buy natural gas from Iran. Just days before his visit, the U.S. Congress passed a $\mathrm{law}^{207}$ intending to isolate states sponsoring international terrorism. The law basically barred third countries from doing business with Iran and Libya. It was a major factor in straining the relations between Ankara and Washington. Erbakan's defiance of the U.S.

\footnotetext{
${ }^{203}$ Yavuz, "Turkish-Israeli Relations through the Lens of the Turkish Identity Debate.", p. 30

${ }^{204}$ See the underpinnings of Erbakan and Welfare Party's ideology, Gencer Ozcan, Onbir Ayllk Saltanat: Siyaset, Ekonomi Ve Dis Politikada Refahyol Donemi (Istanbul: Boyut Kitapları, 1998).; Y. Akdogan, Siyasal Islam: Refah Partisi'nin Anatomisi (Sehir Yayinlari, 2000).; Dogan Duman, Demokrasi Surecinde Turkiye'de Islamcılık (Izmir: Dokuz Eylul Yayınları, 1997).

${ }^{205}$ Steven Erlanger, "New Turkish Chief's Muslim Tour Stirs Us Worry," New York Times August 10, 1996.

${ }^{206}$ Stephen Kinzer, "Meeting Us Envoy, Turkish Premier Takes Pro-Arab Stance " New York Times 3 July 1996. Cited in Yasemin Çelik, Contemporary Turkish Foreign Policy (Westport, Conn.: Praeger, 1999)., p. 83

${ }^{207}$ On August 5, 1997, ibid.
} 
in the foreign arena continued when he paid a visit to Libya, another adversary of the United States. Erbakan's initiatives fell short of any real accomplishments, especially his trip to Libya, on which Libyan leader Qaddafi scolded him for Turkey being a puppet of the west. ${ }^{208}$ Erbakan's humiliations deeply resonated not only among the Kemalist elite but also in Turkish society. His silence after Qaddafi's reprimand was an unacceptable affront to Turkish honor and dignity. ${ }^{209}$ His extremist rhetoric and anti-western, antiIsraeli rumblings were somewhat toned down as a result of overwhelming pressure from the Kemalist establishment, especially the military. In a way, his utopian ideology faltered against the stark realism of Turkey's complicated and dynamic intermingling of domestic and foreign policy challenges. However, the military was extremely uncomfortable with Erbakan's inflammatory behavior. ${ }^{210}$ The Chief of the General Staff, Ismail Karadayi, hastily visited Israel in February 1997 to counterbalance Erbakan's drift toward Islamist nations; he intended to show off the military's leverage in determining the true orientation of the Turkish foreign policy. ${ }^{211}$ More importantly, the military demonstrated its power in domestic affairs through the National Security Council (NSC)

\footnotetext{
${ }^{208}$ Ibid.

${ }^{209}$ See Hurriyet, Zaman, Milliyet, Sabah and Cumhuriyet on October 6, 1996. All criticized Erbakan's ineptitude in handling Qaddafi's scolding. "Para Icin Degmez ", Milliyet October 7, 1996.; "Hoca'yi Terleten Diyalog," Milliyet October 7, 1996.; "Tam Bir Fiyasko," Milliyet October 7, 1996.; "Ciller Kaddafi'ye Sert Cikti: Haddini Bil," Zaman October 8, 1996.

${ }^{210}$ See the perception of the Turkish military on Islamism and the Welfare Party, Ali Bayramoglu, 28 Şubat: Bir Müdahalenin Güncesi (Istanbul: Birey, 2001).; Mehmet Altan, Darbelerin Ekonomisi (Afa Yayinlari, 1990).; Ali F. Demir, Türk Dış Politikasında Liderler: Süreklilik Ve Değişim, Söylem Ve Eylem (Baglam, 2007); Yavuz Donat, Cumhuriyetin Kara Kutusu: Süleyman Demirel Anlatiyor, 2 ed. (Istanbul: Merkez Kitapcilik ve Yayincilik, 2005).; Mehmet Ali Birand, Shirts of Steel: An Anatomy of the Turkish Armed Forces (London: I. B. Tauris, 1991).; Murat Belge, Modern Türkiye'de Siyasi Dü̈sünce, vol. 7 (Iletisim Yayinlari, 2005).

${ }^{211}$ Yavuz, "Turkish-Israeli Relations through the Lens of the Turkish Identity Debate."
} 
on February 28, 1997. What is dubbed as the "February $28^{\text {th }}$ process" in the Turkish political lexicon was initiated when the military through the NSC practically forced the Erbakan government to agree on curbing Islamic social and political movements in Turkey. Many in Turkey considered the February $28^{\text {th }}$ process as a "post-modern coup." 212 Rumors about the alleged U.S. involvement in encouraging the Turkish military abounded in the Turkish media. ${ }^{213}$ However, one recent revelation from an aging Erbakan has ignited a debate as to whether the U.S. was behind the postmodern coup in 1997. Samil Tayyar from the Star daily published an article on December 15, 2010 about an alleged U.S. national security document which suggested that the U.S. administration of the time was very uneasy with the Erbakan government and its policies, and even urged the Turkish military to take appropriate action against him. ${ }^{214}$ It was claimed that thenSecretary of State Warren Christopher sent a document to the U.S. Ambassador to Turkey on October 30,1996, stating that the U.S. was extremely concerned to see that Turkish government was drifting away from the western world and moving toward the Arab world. According to the alleged document, Turkey should remain a key strategic ally of the U.S.; the Turkish military should take action against the current government. Erbakan argued that the alleged document clearly indicated the role of the United States

\footnotetext{
${ }^{212}$ This term was first coined by Turker Alkan in his column in Radikal on June 13, 1997, and was popularized by Cengiz Candar in the foreign media and think tanks. See Turker Alkan, "Postmodern Bir Askerî Müdahale," Radikal June 13, 1997.

${ }^{213}$ See Yenisafak February 28, 2002; Milliyet February 27, 2003; Cumhuriyet February 27, 2002; Hurriyet February 28, 2005.

${ }^{214}$ Samil Tayyar, "28 Şubat Talimatı Abd'den (February 28th Order Was from the United States)," Star December 15, 2010.
} 
in urging the Turkish military to topple his government. ${ }^{215}$ Whether or not the United States was involved in toppling the Erbakan government, however, the "post-modern coup" left very deep social, political, economic and even foreign policy prerogatives for the Turkish military. ${ }^{216}$ The Turkish military-bureaucratic elite immediately sought to regain the hegemonic discourse based on the "homogenizing policies of Kemalism" 217 by instituting sweeping measures in the areas of education, media, politics, economy, culture and international affairs. For example, universities were asked to set up "persuasion rooms" for female students who wore headscarves. Inside, these students were "educated" in modernity and literally forced to remove their headscarves in order to be able to enter university campuses. In short, the post-modern coup was in fact a serious blow to Turkey's democratization and the reforms taken to fulfill the EU accession process. The collision of the secularist military and the Islamist WP resulted in a highly fractured society, after which the normalization of politics and society would take more than a decade.

Gearing towards Strategic Partnership between Ankara and Washington

Given the complexity and the depth of the growing relationship between Ankara and Washington in the second half of 1990s, Mesut Yilmaz, who became Prime Minister after the Islamist Erbakan government resigned on June 18, 1997, paid a visit to President

\footnotetext{
${ }^{215}$ Ibid.

${ }^{216}$ The Chief of the General Staff Huseyin Kivirkoglu claimed that the February $28^{\text {th }}$ is a process. If bacwardism (read Islamism) continue, the "February $28^{\text {th }}$ process" will continue a thousand years. See "28 Subat Bitmedi ", Milliyet September 4, 1999.

${ }^{217}$ Coined by Hakan Yavuz. See typical Kemalist arguments, Emre Kongar, Yozlasan Medya Ve Yozlasan Turkiye (Ankara: Remzi Kitabevi, 2003).
} 
Clinton in December 1997. ${ }^{218}$ Just after a rejection from the European Union at the Luxemburg Summit that faulted it for not including Turkey in the next wave of the enlargement, Yilmaz's visit in a way looked for assurances from the U.S. administration. In fact, Yilmaz and Clinton decided to elevate their enhanced partnership to a "strategic partnership" by expanding the scope of bilateral relations. The Clinton administration declared a "five-part agenda" in the areas of energy, economic issues, security cooperation, regional cooperation and the issues on the Aegean Sea and in Cyprus. ${ }^{219}$ "The impetus behind extending the relationship into the economic sphere was twofold. First, the Turkish government held that the deepened security relationship necessitated expanded economic ties... Ankara sought 'trade not aid,' seeking the relaxation of U.S. import duties on Turkish goods. Second, Washington viewed economic ties as a means of securing Turkey's westward orientation, improving its European prospects and encouraging democratic reforms." ${ }^{220}$ One must also note that previous bilateral economic steps also resulted in the announcement of the five-part agenda between Ankara and Washington in 1990s. Economic ties were placed under an institutional framework when the "Joint Economic Commission" and the "Business Development Council" were created in 1993 and 1996, respectively. Their agreement on agricultural cooperation was renewed in 1995. In 1996, another agreement was signed to eliminate double taxation in trade between Turkey and the United States. After the "five-part agenda" declaration, the

\footnotetext{
${ }^{218}$ Hurriyet December 21, 1997; Milliyet December 20, 1997.

${ }^{219}$ Rachel Prager, "Turkish-American Relations: Historical Context and Current Issues," (Turkish Industrialists' and Businessmen's Association, 2003).

${ }^{220}$ Ibid., p 8.
} 
"Development of Trade and Investment Relations" agreement was signed when Prime Minister Bulent Ecevit visited President Clinton in Washington on September 28, 1999. ${ }^{221}$ According to the U.S. State Department "Country Commercial Guide" report on Turkey in 1998, "the volume of bilateral trade--over $\$ 5.5$ billion--strongly favors the United States. Turkey exported $\$ 2.12$ billion to the United States in 1997 , with apparel and textiles, tobacco and iron \& steel dominating. U.S. exports to Turkey last year totaled $\$ 3.54$ billion and was led by aircraft and spare parts, machinery and tobacco. Total U.S. investment in Turkey, as of the end of 1997, was $\$ 2.2$ billion.."222 The main Turkish position in late 1990s was that "security dominated bilateral relations had to be diversified and that the U.S. had to relax some of its import duties on goods imported from Turkey." ${ }^{223}$ The commitment on the diversification of the nature of the relations, to a certain degree, was met by the United States. The trade volume between Ankara and Washington increased 70\% between 1991 and 1999. The volume of the foreign direct investments by American companies in Turkey tripled in 1990s as compared to the previous decade. The number of American tourists visiting Turkey also significantly increased from 79,000 in 1991 to 439,000 in $1998 .{ }^{224}$ However, some of the protectionist measures, especially on the issues of a quota for Turkish textiles, created contention. In

\footnotetext{
${ }^{221}$ Abdullah Akyuz, "Us-Turkish Economic Relations on the Outset of the 21st Century," (Washington, DC: Turkish Industrialists' and Businessmen's Association, October 2000).

222 "Country Commercial Guide: Turkey Fiscal Year 1999," ed. The United States State Department (Washington, DC: August 7, 1998).

${ }^{223}$ Akyuz, "Us-Turkish Economic Relations on the Outset of the 21st Century.", p. 2

${ }^{224}$ Ibid.
} 
fact, the quota on Turkish textiles was one of the permanent agenda items in bilateral meetings throughout the 1990s.

In addition to the bilateral economic relations, strong U.S. support for the BakuCeyhan oil pipeline and the Trans-Caspian gas pipeline projects, both of which were planned to pass through Turkey, strengthened Turkish-American relations. The main objectives behind these two initiatives were two-fold: the first was to diversify energy routes as more countries were demanding more oil and natural gas for their growing economies. The second was to secure energy routes that passed through politically stable counties. By default, it would limit the roles of Iran and Russia, inhibiting their abilities to dominate energy markets while taming their regional strategic ambitions. Advocating these two projects in fact signaled that the U.S. sought Turkey as a regional hub for energy flow and that the newly-instituted "strategic partnership" between Ankara and Washington in fact was reassuring to both sides. ${ }^{225}$

One of the most important components of the strategic partnership was of course on the issue of arms sales to Turkey. As mentioned earlier, Turkey's quest for a massive military modernization required the purchases of large amounts of arms. In fact, $80 \%$ of the Turkish Armed Forces equipment came from the U.S. From 1993 to 1999, Turkey purchased arms from the U.S. to the tune of $\$ 5$ billion. ${ }^{226}$ Additionally, the U.S. government provided subsidized surplus military equipment valued about $\$ 2$ billion from

\footnotetext{
${ }^{225}$ See Prager, "Turkish-American Relations: Historical Context and Current Issues.", Akyuz, "Us-Turkish Economic Relations on the Outset of the 21 st Century."

226 "Foreign Military Sales, Foreign Military Construction Sales and Military Assistance Facts," ed. Defense Security Assistance Agency (1998).
} 
1991 to $1998 .^{227}$ To illustrate the content of surplus transfers to Turkey, one can examine lists with entries like: "922 main battle tanks, 250 armored personnel carriers, 72 artillery pieces, 145 combat aircraft, 42 helicopters, and 9 combat ships." ${ }^{228}$ While the U.S. Congress, facing pressure from Greek and Armenian diasporas, made occasional threats of arms embargo, it did not change the fact that the U.S. was the top arms-seller to Turkey throughout 1990s.

In conclusion, the relations between Ankara and Washington in the 1990s were qualitatively different in terms of their scope, depth, complexities and magnitude, as compared to the nature of relations in previous decades. Assistant Secretary of State Richard Holbrooke testified in March 1995 before the U.S. Congress and said that "Turkey is at the crossroads of almost every issue of importance to the United States on the Eurasian continent." 229 The relative simplicity and predictability of the Cold War strategic environment on the Turkish-American relations was no longer applicable during the 1990s. The issues ranged from the Gulf War, the emerging de facto Kurdish state in northern Iraq, Turkey's bid for the EU membership to the triangular strategic alliance between Turkey, Israel and the U.S. coupled with Turkey's own Kurdish problem at home, the rise of the Islamist WP to power and an increase in the visibility of a new elite mainly from Anatolian cities. Once the foreign policy decision-making in Turkey was considered to be exclusive to the Turkish civil-military bureaucratic elite, the burgeoning

\footnotetext{
227 "Congressional Presentation for Foreign Operations, Fy 1990-2000," ed. US Department of State (2000).

${ }^{228}$ William D. Hartung Tamar Gabelnick, and Jennifer Washburn, "Arming Repression: Us Arms Sales to Turkey During the Clinton Administration," (the World Policy Institute and the Federation of American Scientists October 1999).

229 "Country Commercial Guide: Turkey Fiscal Year 1999."
} 
new social and political elites from the periphery began, to a certain degree, to exert influence on the U.S.-Turkey relationship. Even in its developmental stage in the 1990s, the role of emerging social and political agency on Turkish politics and foreign policy would be seen in the 2000 s, especially after the rise of Justice and Development Party (JDP) (Adalet ve Kalkinma Partisi). Therefore, the next chapter will explore the dynamic and complex interactions of new Turkish political actors and the United States' policies of its "war on terror" and the Iraqi War of 2003. 
CHAPTER V: TOWARDS AUTONOMY, 2001-2005

The relationship between Ankara and Washington was elevated to a "strategic partnership" in the late 1990s, as laid out in Chapter IV, despite a divergence of opinions and perceived interests on both sides. The Clinton administration's extensive engagement strategy with Turkey largely centered on the conviction that Turkey was an indispensible ally ${ }^{230}$ in furthering the American agenda of promoting economic interdependence and democracy in the region. ${ }^{231}$ Then-U.S. Ambassador-designate to Turkey, Mark Parris, in his confirmation hearing before the Senate Foreign Relations Committee said that "Turkey is important to the United States of America... because of its influence on a remarkably broad range of American interests: from bringing peace to Bosnia to bringing peace to the Middle East; from containing Iraq and Iran to opening up the New Independent States of central Asia; from solving the problem of Cyprus to normalizing the situation in the Caucasus; from combating regional terrorism to shutting down drug trafficking. Turkey is important to us as a paradigm: it is a large, predominantly Muslim country in a troubled region with a tradition of secular governance and expanding democracy, with a 70-year commitment to integration and cooperation with the West, and with a 50-year record of standing shoulder to shoulder with American forces from Korea

\footnotetext{
${ }^{230}$ Strobe Talbott, "U.S.-Turkish Relations in an Age of Interdependence," in Turgut Ozal Memorial Lecture (Washington, DC: Washington Institute on Near East Policy, October 14, 1998 ).

231 "A National Security Strategy of Engagement and Enlargement," ed. The White House (Washington, DC: February 1996). This document was renewed in 1998. See "A National Security Strategy for a New Century," ed. The White House (Washington, DC: October 1998). The document covered Turkey in the following fashion. "Tensions on Cyprus, Greek-Turkish disagreements in the Aegean and Turkey's relationship with the EU have serious implications for regional stability and the evolution of European political and security structures. Our goals are to stabilize the region by reducing longstanding GreekTurkish tensions and pursuing a comprehensive settlement on Cyprus. A democratic, secular, stable and Western-oriented Turkey is critical to these efforts and has supported broader U.S. efforts to enhance stability in Bosnia, the NIS and the Middle East, as well as to contain Iran and Iraq."
} 
to the Gulf War to Somalia to Bosnia."232 The U.S. Assistant Secretary of State Richard Holbrooke claimed in 1995 that "Turkey was as important in the new era as West Germany had been during the Cold War."233 The U.S. Department of State's report to Congress in 1999 also reflected the Clinton administration's overarching perspective on Turkey. "Turkey is vitally important to U.S. interests. Its position athwart the Bosphorus - at the strategic nexus of Europe, the Middle East, the Caucasus and the Caspian - makes it an essential player on a wide range of issues vital to U.S. security, political and economic interests. In a region of greatly weak economies and shaky democratic traditions, political instability, terrorism and ethnic strife, Turkey is a democratic secular nation that draws its political models from Western Europe and the United States."234 On the Turkish side, President Demirel shared similar convictions when he hosted President Clinton in November 1999. He noted that "[c]ommon areas of interest and action between Turkey and the United States are rapidly expanding. We are working together for peace, stability, welfare and security of a vast geography, from the Balkans to the Caucasus, from Central Asia to the Middle East and Europe, and developing together a political agenda in accordance with the new political conditions in the world.",235 Nonetheless, sources of friction between Ankara and Washington ranged from the future

\footnotetext{
${ }^{232}$ Mark Parris, "Ambassador-Designate Mark Parris Statement at Confirmation Hearing," ed. Senate Foreign Relations Committee (Washington, DC: September 23, 1997).

${ }^{233}$ Zalmay Khalilzad, "Why the West Needs Turkey," Wall Street Journal December 22, 1998.

234 "Congressional Presentation for Foreign Operations for Fy 1999 ", ed. The US Department of State (Washington, DC: 1999)., p. 339

235 "Suleyman Demirel Ve Abd Başkanı Bill Clinton'ın Çankaya Köşkü'ndeki Konusmalari ", ed. TC Disisleri Bakanligi (Ankara: November 15, 1999).
} 
of the Kurdish administration in northern Iraq to the compensation of Turkey's economic loss due to the UN embargo in Iraq to human rights violations against Kurds in the 1990s. Just before the end of President Clinton's second term in office, one important element determined the Turkish perception of the United States: the Clinton factor. President Clinton paid a visit to Turkey three days after a powerful earthquake hit the city of Bolu in November $1999,{ }^{236}$ where he met with victims in the quake-ravaged city. ${ }^{237}$ His friendly demeanor in talking to people and effectively communicating with them was well-received by the Turkish public. Images of him walking through tents and hugging a one-year old baby boy named Erkan, who famously squeezed Clinton's nose, resonated among the Turkish populace. ${ }^{238}$ During his visit to Turkey, he also gave a speech at the Turkish Parliament, becoming the first western leader to address the deputies there. ${ }^{239}$ Arguably, the image of the United States in the eyes of both the Turkish elite and public

\footnotetext{
${ }^{236}$ The earthquake, with a 7.2 magnitude, killed close to 1,000 people and wounded about 5,000. A month prior to the Bolu earthquake, another quake, one of Turkey's most destructive, hit with a 7.4 magnitude on August 17, 1999, killing more than 18,000 wounding 44,000. See Milliyet November 16, 2000 and Zaman August 17, 2000.

${ }^{237}$ Then- First Lady Hillary Clinton and their daughter joined him during the visit.

${ }^{238}$ Baby Erkan and Clinton news were widely covered for days in Turkey. See Hurriyet, Milliyet, Zaman, Cumhuriyet, Sabah, Radikal and Yenisafak between November 17 and 21, 1999. Without exception, the coverage on Clinton's visit to Izmit was reflected positively even if some newspapers did have serious reservations towards American policies.
}

${ }^{239}$ Hurriyet's headline read on November 16, 1999, "I promise", referring to Clinton's assurance on U.S. support for the EU membership bid, which would be realized next month in December in Turkey's favor in Helsinki Summit. He said that "[o]n the edge of a new millennium, we have a rare opportunity to reflect upon our journey - two nations that started in very different places, with a shared commitment to democracy, who now must forge a partnership relevant to the new era... Turkey's past is key to understanding the 20th century. But, more importantly, I believe Turkey's future will be critical to shaping the 21st century." He received a standing ovation from them members of the parliament, in which many nationalist deputies seriously doubted the American intentions in northern Iraq. See "Remarks by the President in Address to the Turkish Grand National Assembly," ed. The White House (Washington, DC: November 15, 1999). 
was at its highest point in years in late 1999. This was, in large part, the result of Clinton's popularity and the U.S. push for Turkey's EU candidacy.

When George W. Bush took office in January 2001, the usual sources of friction came to the table even as he assured Turks that the U.S. would respect Turkey's (and Iraq's) territorial integrity and signaling that the U.S. did not intend to support the creation of an independent Kurdistan. Prime Minister Ecevit criticized the United States for not informing the Turkish government of its bombings in Iraq ${ }^{240}$ and Turkish foreign minister Ismail Cem relayed the Turkish government's concern over sanctions against Iraq, which bore a devastating impact on Turkish economy. ${ }^{241}$ However, one of Turkey’s major economic crises erupted on February 21, 2001 when the Istanbul Stock Exchange plummeted more than $18 \%$, a record fall in its history, in one day. ${ }^{242}$ Never-ending relations with the IMF in economic stabilization programs, overvaluation of the Turkish lira and a nearly unregulated, weak financial sector led to one of Turkey's most painful economic crises. Twenty-two out of eighty Turkish banks were bailed out by the government, costing the Turkish taxpayers billions of dollars. Unemployment increased dramatically from 6.5 percent in 2000 to more than 10 percent in February 2001, when

\footnotetext{
${ }^{240}$ Zaman February 18, 2001.

${ }^{241}$ Milliyet February 27, 2001.

${ }^{242}$ The trigger for the massive economic crisis started when President Necdet Sezer reportedly threw the constitution booklet at Prime Minister Ecevit in a National Security Council meeting on February 19, 2001. Ecevit said that Sezer's action was tremendously disrespectful and unprecedented in the republican history. He stated that Sezer might have had issues with his government but the way he had acted was inappropriate. See extensive coverage on the details of the crisis in Hurriyet, Sabah, Radikal, Zaman, Yenisafak, Cumhuriyet and Milliyet on February 20, 2001.
} 
the economic crisis started. ${ }^{243}$ Ecevit invited Kemal Dervis, ${ }^{244}$ then in the United States, to return to Turkey as Minister of Economic Affairs, a post in which he would undertake Turkey's economic recovery program in March 2001. The Turkish government immediately asked the IMF's and U.S.'s help in stabilizing the economy. After long and grueling negotiations on austerity measures, the IMF extended $\$ 19$ billion credit to Turkey on May 15, 2001. ${ }^{245}$ However, painful memories of the crisis and Ecevit's invitation of Dervis ${ }^{246}$ from the U.S. triggered resentment among Turkey's nationalists and Islamists segments. Some claimed that Kemal Dervis was the "clerk" of the IMF and served U.S. interests rather than Turkey's. ${ }^{247}$ In fact, his effective leadership in formulating and implementing the economic recovery program despite popular discord at the time was credited for Turkey's long-term growth under the JDP's rule since 2002. ${ }^{248}$ Allies Agreed and then Disagreed: The September 11 Attacks, and the Polices of "War on Terror" and "Axis of Evil"

While Turkey was dealing with a deep economic crisis at home, the September 11, 2001 attacks on the United States' symbols of power, the World Trade Center and the

\footnotetext{
${ }^{243}$ These were the official numbers from the Turkish Statistical Institute, a government institution. Real unemployment numbers could be much higher given that government data on unemployment was not reliable at that time in Turkey.

${ }^{244}$ A Turkish citizen, Kemal Dervis worked at the World Bank in Washington for more than two decades and was Vice President at WB before he accepted Ecevit's invitation.

${ }^{245}$ Prime Minister Ecevit accused both the U.S. and EU failing to act quickly to get Turkey out of the economic crisis. Cumhuriyet March 18, 2001. See news on the IMF's credit, Milliyet May 16, 2001.

${ }^{246}$ See Dervis' perspective on the economic crisis, Yusuf Kemal Dervis and Serhan Asker and Isik, Krizden Çikis Ve Çagdas Sosyal Demokrasi: Kemal Dervis Anlatiyor, 2 ed. (Istanbul: Dogan Kitapcilik, 2006).

${ }^{247}$ See arguments in Yenisafak August 28, 2002; Aksam October 15, 2001.

${ }^{248}$ Erdogan conformed to the IMF's stabilization program for the 2001 economic crisis and largely avoided populist policies that were followed by many preceding governments.
} 
Pentagon, understandably shocked Turkey. The scope, magnitude and execution of the terrorist attacks of massive proportion in New York and Washington were incomprehensible worldwide, including in Turkey. The general thinking among the Turkish political elite and the public was that the world's sole super power could not be attacked. ${ }^{249}$ Seeing such attacks inflicted by a non-state actor, Al-Qaida, on U.S. soil deeply disturbed assumptions about international relations and the future of the nationstate system. Many in Turkey uttered that a new era of uncharted territory in international affairs started on September 11, 2001. ${ }^{250}$ In that same vein, the Turkish political elite ${ }^{251}$ acknowledged the unprecedented nature of the attacks and unequivocally claimed that the "Turkish thesis" of dealing with terrorism was vindicated in the aftermath of the attacks. Turkey had been dealing with the menace of terrorism since 1984 and the ensuing conflicts had resulted in more than 35,000 casualties and $\$ 100$ billion in economic losses. As laid out in preceding chapters, Turkey largely employed military-security based approaches to its Kurdish problem at home and possible de facto Kurdish state in northern Iraq in 1990s and early 2000s. Military operations in southeastern Turkey led to widespread human rights violations among its Kurdish citizens and drew criticism from

\footnotetext{
${ }^{249}$ Prime Minister Ecevit said that he could not "conceive that another state would do such a thing against the United States." See Turkish Daily News September 14, 2001.

${ }^{250}$ See newspaper articles by leading columnists Cengiz Candar Yenisafak September 12, 2001; Ertugrul Ozkok Hurriyet September 12, 2001; Fehmi Koru Yenisafak September 12, 2001; Hasan Cemal Milliyet September 13, 2001.

${ }^{251}$ Regardless of their political agenda or ideological stance, the Turkish political elite unequivocally condemned the attacks. President Sezer condemned in the strongest terms the attacks on the United States. He shared the grief and anguish felt by friend and ally, the United States. See Hurriyet September 12, 2001. Prime Minister Ecevit, coalition government leaders Mesut Yilmaz of the Motherland Party and Devlet Bahceli of the Nationalist Action Party strongly denounced terrorist attacks. Opposition leaders Tayyip Erdogan of the Justice and Development Party said "[i]t does not matter who made these attacks, the entire family of mankind should not stop with condemning these cowardly attacks but should unite in common struggle against these attacks." See Turkish Daily News September 13, 2001.
} 
the United States and even more so from European countries. Turkey's occasional crossborder incursions, named "hot pursuits" by the Turkish military, in northern Iraq to root out PKK elements also caused the bombings of Kurdish villages that outraged the international community. Against this backdrop, Turkey repeatedly brought the issue of dealing with international terrorism to the attention of the international community in various venues to convince its counterparts to institute a common anti-terrorism policy. It was largely unsuccessful because of Turkey's human rights records and the influence of the Kurdish diaspora in European countries. However, it is important to note that the European reluctance to limit PKK activities in European cities, and its refusal to recognize the PKK as a terrorist organization (instead identifying it as a "separatist group") were constant and major sources of friction. Although the U.S. designated the PKK a terrorist organization, Turkey remained uncomfortable about the "future intentions" of the western world, including the U.S. After witnessing the terrorist attacks in the U.S.in September 2001, the Turkish political elite felt vindicated in their antiterrorism approach of forging a consensus between nations to deal with terrorism. These sentiments could best be described in the words of President Necdet Sezer when he said that no country except Turkey could understand the pains and sufferings of the United States. "We are ready to share our experience, which we have gained over 15 years."252 He also argued that those attacks should be a lesson for European countries. He urged their leaders to adopt changes in their attitudes and states of mind towards terrorism. After pointing out that terrorism was a crime committed against all humanity, he said,

${ }^{252}$ Turkish Daily News September 15, 2001; Sabah September 15, 2001. 
"that's why we have always repeated in all international platforms that international cooperation in the fight against terrorism should be improved. The attacks on the U.S. had shown how correct Turkey is in her stance against terrorism. I guess the attitudes of European countries have begun to change too." ${ }^{, 253}$ The same sentiment was shared by the former Turkish Ambassador Yuksel Soylemez in his op-ed essay titled "My Terrorist May Be Your Friend." ${ }^{254}$ While acknowledging the concerted U.S. efforts for more united front against international terrorism over the years, he noted that some European nations did not pay enough attention to the problem and even supported terrorists groups, alluding to the PKK presence in Europe. He bluntly said that " $[\mathrm{m}] \mathrm{y}$ terrorist should not be your friend or vice versa. There cannot or should not be different and contradicting definitions of the terrorist, which unfortunately has been the case up until now." ${ }^{255}$ What could be dubbed as the "we were right" view among the Turkish elite were fiercely employed when meeting with European counterparts as they pressured Europeans to take strong measures on the PKK activities in their borders. This led to success in European countries identifying the PKK as a terrorist organization.

On the implications of terrorist attacks on the U.S., President Bush hinted his response and the new orientation of the country when he said at the National Cathedral on September 14, 2001 "[j]ust three days removed from these events, Americans do not yet have the distance of history. But our responsibility to history is already clear: to

\footnotetext{
${ }^{253}$ See Hurriyet, Zaman, and Cumhuriyet 13 September 2001; Necdet Sezer, "I Reckon Western Countries Are Going to View Terrorism Differently from Now On," Turkish Daily News 13 September 2001.

${ }^{254}$ Yuksel Soylemez, "My Terrorist May Be Your Friend," Turkish Daily News 13 September 2001. ${ }^{255}$ Ibid.
} 
answer these attacks and rid the world of evil. War has been waged against us by stealth and deceit and murder. This nation is peaceful, but fierce when stirred to anger. The conflict was begun on the timing and terms of others. It will end in a way, and at an hour, of our choosing., ${ }^{256}$ Less than a week later, he laid out his plan for responding to terrorists and their supporters by saying that "we will starve terrorists of funding, turn them one against another, drive them from place to place until there is no refuge or no rest. And we will pursue nations that provide aid or safe haven to terrorism. Every nation in every region now has a decision to make: Either you are with us or you are with the terrorists." ${ }^{257}$ His threatening rhetoric of "either with us or against us" did not bother either President Sezer or Prime Minister Ecevit (or, for that matter, the Kemalist intellectuals) since they thought that a rising tide of anger against radical Islam in the world served to bolster Turkey's success story as a secular Muslim country. The September 11 attacks, according to them, reaffirmed the wisdom of Kemalist Turkey and increased its strategic importance in the start of this new era. ${ }^{258}$ Turkey offered its unconditional support to the U.S., signaling its goodwill but also calculating its interests on the premise that its strategic value was increasing in the eyes of the U.S. For this

\footnotetext{
${ }^{256}$ George W. Bush, "Transcript of President Bush's Prayer Service Remarks: National Day of Prayer and Remembrance for the Victims of the Terrorist Attacks on September 11, 2001," ed. The White House (Washington, DC: September 14, 2001).

257 "The Full Text of President Bush's Address to Joint Session of Congress," http://www.foxnews.com/story/0,2933,34782,00.html. Emphasis added.

${ }^{258}$ Renowned liberal columnist Cengiz Candar stated that the new process with September 11 started the elimination of radical Islam. Evaluating radical Islam as a political phenomenon of the 21 st century, he argued the incompatibility between the $20^{\text {th }}$-century radical Islam and those of the 21 st century. See Yenisafak October 19, 2001. Conservative columnist Ahmet Tasgetiren on the other hand argued that radical Islam was picked as the new enemy in the framework of NATO's search for a new mission after the demise of the Soviet Union, but this policy was not applied till September 2001 because it could create enmity against the West in the Islamic world. See his column Yenisafak October 18, 2001.
} 
purpose, on October 10, 2001, the Turkish parliament granted full war powers to Ecevit's government, giving it the right to send troops abroad or host foreign troops on Turkish land. Additionally, it allowed the government to authorize foreign aircrafts' usage of Turkish airspace, in an attempt to help the U.S. fight Al Qaida and the Taliban in Afghanistan. ${ }^{259}$ Turkey's full support for the American mission met with American jubilation. In fact, U.S. Congressman Curt Weldon described Turkey as the "shining crown jewel" ${ }^{260}$ in a tumultuous region and Congressman Robert Wexler declared that there was no other country that matched Turkey's level of support for America's fight against terrorism after the September $11^{\text {th }}$ attacks. ${ }^{261}$ In his visit to Washington in January 2002, Bulent Ecevit reaffirmed Turkey's commitment to fight terrorism and its continued support to work in Afghanistan to root out terrorist elements.

Even though the September 11 attacks generated a sense of understanding in Turkey, whose people sympathized with the destruction and the loss of life that blighted the U.S. in unprecedented proportions, the Turkish elite was deeply concerned about the Bush administration's policies of unilateralism and pre-emptive war $^{262}$ as unveiled in the September 2002 National Security Strategy document. ${ }^{263}$ Many in Turkey thought that unrestrained American power would create excesses and lead to instability and war in an

\footnotetext{
${ }^{259}$ Milliyet October 11, 2001.

${ }^{260}$ Economist, Turkey strongly backs America-but is reluctant to make Iraq a target too Oct 11, 2001

${ }^{261}$ Hurriyet February 18, 2002.

${ }^{262}$ The Bush policies after September 11 were dubbed the "Bush Doctrine." See "Aftermath; the Bush Doctrine," New York Times April 13, 2003.

${ }^{263}$ See "The National Security Strategy of the United States of America," ed. The White House (Washington, DC: September 2002).
} 
area of worrying proximity to Turkey. ${ }^{264}$ Additionally, the "war on terror" policies made conservative circles in Turkey especially uncomfortable since they inherently led to the marginalization of Islam in the public opinion and the belief that the U.S. saw Islam as a threat against which it would use tough counter-measures. ${ }^{265}$

Strategic Partnership in Jeopardy: Iraqi War of 2003

The Turkish elite's major concern was that the U.S. would not stop with toppling the Taliban in Afghanistan but expand its agenda to Turkey's neighboring states, especially Iraq. The U.S. request from the Turkish government to open its Combined Air Operation Center, a NATO base in the central Anatolian city of Eskisehir, signaled an intention to strike Iraq in the near future. ${ }^{266}$ The U.S. delegation's visit to northern Iraq reinforced Turks' conviction that the post-September 11 environment would create another episode of the Gulf War, which had enormous political, economic and foreign policy implications for Turkey. The Turkish fear materialized when George W. Bush gave his State of the Union address on January 29, 2002. He labeled Iran, Iraq and North Korea as the "axis of evil", arguing that these states were sponsoring terrorism and pursuing weapons of mass destruction. ${ }^{267}$ Later, Syria, Libya and Cuba were identified as "rogue states" as they, the U.S. argued, also sponsored terrorism and had the potential to

\footnotetext{
${ }^{264}$ See discussions Fehmi Koru, Yenisafak April 13, 2002; Ali H. Aslan Zaman September 15, 2002; Sami Kohen Milliyet July 13, 2002.

${ }^{265}$ The general moods in Zaman, Yenisafak, Milli Gazete and Vakit were grim in reflecting the Bush administration's policies on the Muslim world.

${ }^{266}$ Lale Sariibrahimoglu, "Us Lays Ground Work to Knock on Saddam's Door Via Turkey," Turkish Daily News December 12, 2001.

267 "Transcript of President Bush's First State of the Union Address," CNN, http://edition.cnn.com/2002/ALLPOLITICS/01/29/bush.speech.txt/.
} 
pursue weapons of mass destruction. Ertugrul Ozkok, editor in-chief of Hurriyet daily, broke important news in March 2002 when he wrote that the U.S. would attack Iraq in the near future, citing then-opposition leader Tansu Ciller. Ciller had just returned from the U.S. where senior U.S. officials allegedly shared these intentions with her. ${ }^{268}$

The U.S. definition of Iran and Iraq as an "axis of evil" and of Syria as a "rogue state" pressured Turkey since Bush's "either with us or against us" lexicon did not leave any wiggle room for Turkey. However, it did not mean that critiques of the Bush administration and of the oncoming storm of the Iraqi War stopped. In fact, there was an atmosphere of vigorous debate on the question of what Turkey's policy orientation would be in this new era of American unilateralism. ${ }^{269}$ Some argued that Turkey should join this axis on the side of the U.S. not as a subordinate but on equal terms. ${ }^{270}$ With mounting pressures from the Bush administration to initiate war efforts from north of Iraq, Turkish political elites were left with a dilemma. They had either to side with the U.S. or reject it altogether. ${ }^{271}$

Turks were most concerned about both Kurdish separatism in northern Iraq and the growing possibility of instability associated with its own Kurdish question. In this respect, the post-Gulf War environment and its impact on Turkey's domestic and foreign

\footnotetext{
${ }^{268}$ Ertugrul Ozkok, " Ciller'in Abd'den Getirdiği Önemli Istihbarat," Hurriyet March 11, 2002.

${ }^{269}$ One such example could be given in the case of extensive debates between columnists, liberal Cengiz Candar and conservative Fehmi Koru from Yenisafak. While Cengiz Candar argued that Turkey should be on the side of the U.S. due to its massive power to topple Saddam Hussein, Fehmi Koru, on the other hand claimed that the U.S. would not have any legitimacy in attacking Iraq and that Turkish public overwhelmingly opposed the Turkish siding of the possible war.

${ }^{270}$ Ferai Tinc, "Şer Ekseni Türkiye Için Ne Anlama Geliyor? ," Hurriyet February 4, 2002.; Mehmet A. Birand, " Türkiye, Abd’ye "Hayır" Diyemez," Hurriyet February 12, 2002.

${ }^{271}$ Bulent Aras, Türkiye Ve Ortadoğu: Türk Dış Politikasının Toplumsal Kökenleri (Q-Matris, 2003).
} 
affairs were deeply engrained in Turkish perceptions. Observers must also note arguments that the Bush administration was strongly determined to invade Iraq no matter what, and that Turkish participation in the war efforts could win a seat in the table in the aftermath of the war, which could in turn give Turkey huge leverage in determining the possible establishment of independent Kurdistan. ${ }^{272}$ Even the JDP leader Erdogan argued that Turkey was doing everything in its power to prevent the war but saw the efforts of establishing a new world headed by the U.S. ${ }^{273}$ He went on to assert that Turkey needed to claim its own space in this emerging world. Interestingly enough, there was also a belief not only among columnists but also among members of the parliament that Turkey's non-involvement in the Iraq War could prevent American intentions to invade Iraq due to its high costs. ${ }^{274}$

In January and February of 2002, American officials increased their efforts to open up Turkish soil for American troops to invade Iraq from the North. To entice Turkish leadership in both the government and the military, the U.S. started a negotiation, offering economic incentives in addition to the promise of Turkey's involvement in the post-war equations. What was dubbed in the Turkish lexicon as "at pazarligi" (horse trading) received significant attention in Turkish elite and the public. According to the newspaper accounts, U.S. Secretary of State Colin Powell offered a package of $\$ 6$ billion in grants and $\$ 20$ billion in credit of favorable terms to Turkey in return for the

\footnotetext{
${ }^{272}$ These opinions were largely voiced by Ertugrul Ozkok from Hurriyet, and Cengiz Candar from Yenisafak. See their articles in respective dailies from January to March 2003.

273"Akp'de Tezkere Sıkıntisi ", Hurriyet February 22, 2003.

${ }^{274}$ See Fehmi Koru Yenisafak February 15, 2003.
} 
deployment of American troops in Turkey. ${ }^{275}$ Such negotiations and the degradation of Turkey's participation in economic bargaining spurred huge public outcry. It further galvanized the Turkish public, which negatively viewed the war efforts. On one hand, the JDP leadership, especially Erdogan, was trying to keep deputies in line despite mounting pressure from their constituencies. In the JDP's group meeting on February 26, Minister of Foreign Affairs Yasar Yakis, Minister of Defense Vecdi Gonul and Minister of Economic Affairs Ali Babacan informed the deputies about the possible outcomes of rejecting the resolution in case it did not pass. According to their talking points, the Kurdish state would be established and spark separatism in Turkey. Turkey would not handle fleeing Kurdish refugees from Iraq. The U.S. would no longer support Turkey's EU membership bid and Turkish theses against Greece and Cyprus. Last, but not least, Turkey might experience harsh economic crisis if the U.S. withdrew its economic support. ${ }^{276}$ Adding pressure to the JDP government, President Sezer reminded the deputies that the resolution was coming to the floor of the parliament without international approval from the United Nations. A day before the resolution's vote, the National Security Council did not issue an advisory. This was an unusual gesture given that the military had used significant leverage through the NSC on major issues in Turkish politics over the decades. ${ }^{277}$

\footnotetext{
${ }^{275}$ See extensive media coverage on the offer, on February 20, 2002 in Aksam, Hurriyet, Zaman, Milliyet, Yenisafak, Sabah, Cumhuriyet, Radikal and Milli Gazete.

${ }^{276}$ See Zaman February 26, 2003 and Hurriyet February 26, 2003.

${ }^{277}$ Milliyet February 28, 2003 and Sabah February 28, 2003.
} 
On the American side, the general attitude was that Ankara could not say no because Turkey, they thought, needed more U.S. economic backing amid the ruinous financial crisis in 2001. Additionally, the unprecedented self-confidence of the Bush administration was salient among American leaders following the invasion of Afghanistan. They had a conviction that Turkey could not reject the resolution given the U.S. primacy in the region, that it was unthinkable Turkey to pursue such a treacherous path. ${ }^{278}$ The structural factors were in fact pushing Turkey only in the direction of approving the resolution, not the other way around. However, to the surprise of many, the Turkish parliament did not pass the resolution despite the 264 yes votes and 250 no votes. It was only 3 votes shy of fulfilling majority vote on March 1, 2003. ${ }^{279}$ Despite the fact that Erdogan lobbied hard in his party to pass the resolution, the TGNA sent an unprecedented message to the U.S. indicating that it was heeding the Turkish public's sentiments. I argue that the March $1^{\text {st }}$ rejection was the major breaking point in TurkishAmerican relations and a signifier of Turkey's transformation from the bottom up. Turkish domestic input into the state's foreign policymaking had not been this visible since the establishment of Turkey in 1923. I also claim that rejection of the resolution brought U.S.-Turkey relations to their lowest level since the 1974 arms embargo on Turkey and even surpassed it. In 1974, the U.S. was applying its embargo against Turkey due to the Turkish invasion of Cyprus. However, the March $1^{\text {st }}$ resolution outcome was a

\footnotetext{
${ }^{278}$ Michael Rubin, "A Comedy of Errors: American-Turkish Diplomacy and the Iraq War " Turkish Policy Quarterly (Spring 2005).

${ }^{279}$ For extensive discussions on the resolution and the aftermath, see Murat Yetkin, Tezkere: Irak Krizinin Gerçek Öyküsü, 2 ed. (Ankara: Remzi Kitabevi, 2004).; Umit Ozdag, Türk Ordusunun Kuzey Irak Operasyonlarl (Pegasus Yayinlari, 2008).; Habibe and Osman B. Dinçer and Mehmet Yeğin Özdal, Mulakatlarla Turk Dis Politikasi (Ankara: USAK, 2009).; Mustafa Kayar, Türk - Amerikan Ilişkilerinde Irak Sorunu (IQ Kultursanat Yayincilik, 2003).; Bal, 21. Yüzyılda Türk Dış Politikası.; Cakmak, Turk Dis Politikası, 1919-2008.; Turan Silleli, Türkiye-Irak Iliskkileri (IQ Kultur ve Sanat Yayincilik, 2005).
} 
direct refusal from Turkey that rejected the primacy and unilateralism of the U.S. against the Iraqi invasion. The rejection was qualitatively different in asserting the "new Turkey." Even the JDP leadership did not see the depth and scope of opposition from the Turkish public despite the fact that repeated surveys revealed that over $90 \%$ of the populace opposed the war. Ironically enough, the same event shaped and redefined the perception of Turkey both in the Middle East and Europe. Many in these regions respected Turkey for standing up to the war that they perceived to be illegitimate. ${ }^{280}$ Additionally, staying away from the Iraq war, as revealed in later years, saved the blood and treasure of Turkey. ${ }^{281}$ Turkey's rejection of American troops also attracted sympathy from an unlikely place. The intellectuals and some political leaders in EU nations welcomed the result of the democratic process and noted the independent policy orientation amid immense pressure from Washington.

While noting the emerging independent course of Ankara's relations with Washington, one should also note that Turkey's policy regarding northern Iraq was complicated further. Since Turkey did not play any role in the invasion, Washington elevated its relations with the Kurdish factions, namely Barzani and Talabani, to strategic levels. Turkey's leverage over northern Iraq since 1991 diminished, as had been feared by the foreign affairs bureaucracy for more than a decade. After the war with Saddam Hussein concluded, Kurdish factions organized more effectively than Shia and Sunni groups due to their experience with autonomous government since 1991.

\footnotetext{
${ }^{280}$ See Aras, Türkiye Ve Ortadoğu: Türk Dış Politikasının Toplumsal Kökenleri.; Altunisik, Türkiye Ve Ortadoğu: Tarih, Kimlik, Güvenlik.

${ }^{281}$ Fehmi Koru from Yenisafak repeated his point of staying away from, what he called, the Bush's war in his column several times. See Yenisafak March 2, 2007.
} 
In July 2003, another incident took place that had a huge impact on the already strained relations when U.S. troops in the city of Suleymaniyah arrested a Turkish Special Forces unit and placed hoods on their heads. Images of Turkish troops wearing hoods appeared in newspapers and touched a nerve in Turkey. Many believed that Washington was trying to humiliate the Turkish military and people due to the no-vote in March. Such a minor incident became a major phenomenon and led to the writing of many books (such as Metal Firtina, Metal Storm) and even blockbuster films like Kurtlar Vadisi - Irak (Valley of Wolves - Iraq), which were anti-American in nature. Public sentiments ran high and anti-Americanism significantly increased. Seeing such a downward spiral of Ankara's relations with Washington, many in the U.S. repeatedly asked questions like "who lost Turkey?" and spoke of "whether Turkey was drifting away from the west and especially from the U.S." The spike of negative perception of Turkey in Washington was closely associated with the JDP's rise to power and its identity with an Islamic past. To better grasp the scope, depth and magnitude of the rejection of the March $1^{\text {st }}$ resolution, and the nature of Turkish-American relations afterward, one must examine the dynamic transformation of Turkish society and politics since the early 1980s. In the next section, I will explore Turkey's transformation and its implications on the relationship between Ankara and Washington.

The Contours of Turkey's Transformation in Domestic and Foreign Affairs

The shocking attacks on the U.S. in September 2001 and the U.S. signaling of a possible war with Iraq already complicated Turkish calculations, especially on the issues of northern Iraq and economic recovery challenges from the February 2001 crisis. At this critical juncture, a seismic political shift in Turkish politics was around the corner. 
Mounting challenges of austerity measures and the collapse of the dysfunctional coalition government of Democratic Left Party (DLP), NAP and MP led to an early election on November 3, 2002. Out of 19 parties that had participated in the national elections, surprisingly enough, only two parties succeeded in passing the parliament's venerated 10\% threshold - the Republican People's Party and the newly established Justice and Development Party, which was a reformed offshoot of political Islamist Virtue Party (VP) (Fazilet Partisi). ${ }^{282}$ What's striking was that other major parties, DLP, NAP, MP and others, were left outside of parliament. ${ }^{283}$ All of these parties had been on the Turkish political scene for more than a decade and had been prominent as either governing parties or as opposition groups in the parliament. What made the November 2002 elections unique was that the Turkish public literally erased the political establishment ${ }^{284}$ and notably placed the JDP as the new center of political authority. The RPP had already been out of the parliament for three years and had only captured the solid Kemalist bases' vote that ranged from $20 \%$ to $25 \%$ over the decades. The impressive win by a newlyestablished party indicated that there was a deep transformation in Turkey's populace in shaping the domestic political landscape. Now with more than eight years as a ruling party, ${ }^{285}$ the JDP's power showed that this was not an ephemeral political shift; in fact,

\footnotetext{
${ }^{282}$ Tayyip Erdogan's JDP got $34.28 \%$ of the total votes cast and 363 seats in the parliament while Deniz Baykal's RPP captured $19.4 \%$ of the votes and 178 seats.

${ }^{283}$ Due to crashing results, Tansu Ciller of the True Path Party and Mesut Yilmaz of the Motherland Party resigned from their party chair positions. Devlet Bahceli of Nationalist Action Party resigned from his post but his resignation was not approved by the party committee, so he stayed.

${ }^{284}$ It is important to note that the coalition partners DLP, TPP and NAP got $1.22 \%, 9.55$ and $8.34 \%$ respectively, all under the national threshold to enter the parliament.

${ }^{285}$ In fact, many surveys suggested that the JPD would comfortably win another 4-year term in the elections in June 2011. See various surveys Vatan November 24, 2010; Gazete Haberturk January 20,
} 
their authority brought some of the deepest political transformations since Adnan Menderes' and Turgut Ozal's reforms in the 1950s and 1980s, respectively. Indeed, JDP transformations may well pass those two in terms of scope and magnitude both in the domestic and foreign policy arenas. ${ }^{286}$ As laid out in Chapter IV, Turgut Ozal's liberalization efforts in politics and economy between 1983 and 1993 paved the way for the emergence of new political and economic spaces that were filled largely by periphery ${ }^{287}$ the Anatolian conservative bourgeoisie. They benefitted from economic and political openings in the early 1980s and became competitive in education and business by the mid-1990s. These rising "Anatolian tigers" and the increasing visibility of conservative Muslims in public spaces, especially in education, media and business, gave way for the emergence of a new socio-political elite that engaged with the center through active economic and political participation. Since they largely emerged in a transitional period to capitalism under the Ozal era, they tended to be pro-free market economy and advocated integration with the west, especially the EU, even if they were socially conservative. ${ }^{288}$ In this sense, they were more adaptive than the traditional Kemalist elite, who stumbled when the EU reforms began to challenge defunct aspects of Kemalism

\footnotetext{
2011; Milliyet December 13, 2010.

${ }^{286}$ See discussions on the unprecedented role of the JDP and the transformation of Turkish domestic politics, Zaynep Dagi, Doğu'dan Batı'ya Dış Politika: Ak Parti'li Ylllar (Ankara: Orion Yayinevi, 2006).; Uzeyir Tekin, Ak Parti'nin Muhafazakâr Demokrat Kimliği (Orient, 2004).; Yalçın Akdoğan, Ak Parti Ve Muhafazakâr Demokrasi (Alfa Yayinlari, 2004).; Hakan Yavuz, Modernlesen Muslumanlar: Nurcular, Naksiler, Milli Gorus Ve Ak Parti (Istanbul: Kitap Yayinevi, 2005).; Davut and Burhanettin Duran and Hamza Al Dursun, Dönüşüm Sürecindeki Türkiye: Aktörler, Alanlar, Sorunlar (Ankara: Alfa Yayinlari, 2007).

${ }^{287}$ See the center-periphery discussion on Turkey, Serif Mardin, The Center-Periphery Cleavage: A Key to Turkish Politics? (1972).

${ }^{288}$ See an extensive discussion on the transformation of Turkish domestic landscape and emerging new actors, Dursun, Dönüşüm Sürecindeki Türkiye: Aktörler, Alanlar, Sorunlar.
} 
such as the advancement of democracy, minority rights and privatization. As Hakan

Yavuz argued, “[p]olitical participation provides a variety of flexible learning

opportunities for religious actors to make trade-offs between their ideology and vote-

maximization. In order to exist as a legal party and acquire genuine popular support, religious parties must engage in coalition building and pragmatic compromises." 289 The WP's experience with the Kemalist establishment signaled that religiously-oriented parties needed to garner genuine popular support and establish coalitions from a broad spectrum of society in order to operate in the repressive environment and implement their projects. The JDP's leaders, Tayyip Erdogan, Abdullah Gul and Bulent Arinc, had intense learning experiences during WP's rule in the mid 1990s. It is important to note that from 1994 to 1998, Erdogan was the mayor of Istanbul, a metropolitan city with more than 12 million inhabitants at the time. During his tenure, dealing with the daily needs of ordinary people, such as overseeing trash collection and upgrading infrastructure, shaped his ideas about governance. ${ }^{290}$ Erdogan, Gul and Arinc's departure from Erbakan's VP, and their subsequent formation of a new party should be understood in context whereby their learning process in the office, demands and aspirations of the rising Anatolian bourgeoisie, the interaction with Kemalist establishment and the impact

\footnotetext{
${ }^{289}$ Yavuz, Secularism and Muslim Democracy in Turkey., $\mathrm{p} 47$.

${ }^{290}$ In 2009, the author had a discussion with one of Erdogan's cabinet members. He said that he was also a mayor of a small city in the mid-1990s. Prior to his tenure, he had a vast knowledge of Islamic movements around the world, and genuinely followed their news from the media. He also tended to see himself as thenIslamist. However, he realized that his town had enormous problems ranging from lack of infrastructure for sewage and water system to bad roads when he assumed the office. Being an Islamist could not solve the town's problem. In fact, he needed to pay attention to ever-pressing challenges in the town. Then, he understood that the real service could be made to his people by improving their quality of life, not through ideologically driven Islamism. In a way, dealing with the realities of daily life as an administrator made him pragmatic, and he largely abandoned his previously-held ideology and blended his pragmatism with religious conservative values.
} 
of democracy and globalization intricately intermingled. I argue that the rise of the JDP to power was largely a result of an amalgamation of the above mentioned reasons. Therefore, one could understand why the JDP leaders branded themselves first as "Muslim Democrats," alluding to Christian Democrats in Europe, and then "conservative democrats. ${ }^{, 291}$ The rise of the JDP to power and removal of the traditional political elite in November 2002 elections, however, did not mean that people from the periphery were taking over the Kemalist regime as many Kemalist intellectuals argued. ${ }^{292}$ It instead increased the visibility of entrepreneurs and youth from Anatolian cities, people with conservative-religious values, in the center of cities like Ankara, Istanbul and Izmir, especially in what people perceived were relatively high positions. As Ian Lesser argued, "[i]t is not that the established elites in government, business, and intellectual life have been displaced, but rather that Turkish society and policymaking have become more diverse, with new influences, new sources of identity, and new alliances." ${ }^{293}$

At this juncture, one also needed to understand how other actors like the Kemalist establishment and the United States perceived the JDP and its leadership when they assumed office in November 2002. It was fascinating to see that labeling the JDP was no easy task. There were a wide variety of adjectives used to define the party. Many

\footnotetext{
${ }^{291}$ See discussions on the JDP's "conservative democracy", "Uluslararası Muhafazakarlık Ve Demokrasi Sempozyumu," (Istanbul: Ak Parti, January 2004).; Akdoğan, Ak Parti Ve Muhafazakâr Demokrasi.; Ahmet Cigdem, ed., Muhafazakârlı (Istanbul: Iletisim Yayinlari, 2004).; Ismail Safi, Türkiye'de Muhafazakâr Siyaset Ve Yeni Arayışlar (Lotus, 2007).; Tekin, Ak Parti'nin Muhafazakâr Demokrat Kimliği.; Fuat Keyman, "Modernization, Globalization and Democratization in Turkey: The Akp Experience and Its Limits," Constelleations 17, no. 2 (June 2010).

${ }^{292}$ Ibid.

${ }^{293}$ Ian Lesser, "Beyond Suspicion: Rethinking Turkey-Us Relations," (Washington: Woodrow Wilson International Center for Scholars, 2007).
} 
Kemalists ${ }^{294}$ in Turkey and neo-conservatives ${ }^{295}$ in the U.S. perceived the JDP as "Islamist", "political Islamist," "radical Islamist," or even "Islamo-fascist." While some used "mildly Islamic" 296 or "Islamic", others utilized the term "religiously oriented"297 and "post-Islamist." ${ }^{298}$ It is important to note that the JDP's rule coincided with the postSeptember 11 era, in which the U.S. was determined to eradicate Islamic terrorism and bring democracy to the Middle East. The Bush administration's Greater Middle East Initiative (GMEI) entailed democracy promotion through the expansion of political rights in the Muslim world. It would, they theorized, counter Islamic extremism. ${ }^{299}$ On the one hand, Turkey's unique history as a secular and democratic nation and the JDP's ascension to power seemed fitting in that they promoted Turkey as a model for the Muslim world. ${ }^{300}$ On the other hand, the JDP government's failure to pass the resolution on the

\footnotetext{
${ }^{294}$ To name a few: Ilhan Selcuk and all other columnists from Cumhuriyet, Ozdemir Ince and Yilmaz Ozdil from Hurriyet, Hasan Pulur from Milliyet, some segments of the higher echelons of military-civilian bureaucracy, traditional statist business elite.

${ }^{295}$ Michael Rubin from the American Enterprise Institute and Soner Cagaptay from the Washington Institute for Near Eastern Studies could be identified as such. See Rubin, "A Comedy of Errors: AmericanTurkish Diplomacy and the Iraq War ".; Soner Çağaptay, Islam, Secularism, and Nationalism in Modern Turkey: Who Is a Turk? (New York: Routledge, 2006).

${ }^{296}$ Nathalie Tocci Kemal Kirisci, and Joshua Walker, "Turkey's Transatlantic Value," (New York: German Marshall Fund of the United States, 2010).

${ }^{297}$ Heper, The State and Kurds in Turkey: The Question of Assimilation.

${ }^{298}$ Rusen Cakir from Vatan daily and Philip Robins, "Turkish Foreign Policy since 2002: Between a 'PostIslamist' Government and a Kemalist State " International Affairs 83, no. 1 (2007).

${ }^{299}$ Tamara Cofman Wittes, "The New U.S. Proposal for a Greater Middle East Initiative: An Evaluation," (Brookings, May 10, 2004).

${ }^{300}$ This was not well-received in Turkey, especially among the Kemalist elite, who argued that Turkey could not serve as a model because its western vocation did not fit well with the Muslim world. They basically concerned about the label that associated Turkey with the Muslim world. Kemalist elite disliked any forms of association with the Muslim world. See extensive writings of Ilhan Selcuk from Cumhuriyet, Ozdemir Ince from Hurriyet and Hasan Pulur from Milliyet.
} 
stationing of U.S. troops in Turkey for Iraqi invasion and the deep suspicion of any religiously oriented party's agenda in the post-9/11 era, made the GMEI complicated. ${ }^{301}$ Many in neoconservative circles in the U.S. claimed that the JDP leadership was the prime reason behind the rising anti-Americanism in Turkey. While it was true that public opinion towards the U.S. in Turkey had deteriorated sharply since 2002, similar trends were evident in many other countries, especially Europe, because of the Iraq War and Bush's policies. A survey conducted by the German Marshall Fund of the U.S. in 2006 revealed that only $20 \%$ of the Turkish public felt positively about the U.S. The Pew Global Attitudes Project indicated a sharp decline of the Turkish perception of the U.S. from $52 \%$ in 2000 to $12 \%$ in $2006 .{ }^{302}$ Another research done by the Uluslararasi Stratejik Arastirmalar Kurumu (International Strategic Research Organization, ISRO) in March 2005 found that $91 \%$ of the Turkish public did not approve the policies of the Bush administration while only $0.5 \%$ supported. However, this did not mean that "antiAmericanism" was reflected towards the American people, but at the policies of the government. The ISRO survey also revealed that $74 \%$ of the Turkish public still saw the U.S. as an ally, and only $4 \%$ of the respondents said they hated the U.S. ${ }^{303}$ I should note that sentiments against the U.S. were shared not only by the JDP and conservative segments of society, but also cut across social-political segments in the society, and found representation in almost all major political and social groups except in a small

\footnotetext{
${ }^{301}$ Neoconservatives in the Bush administration felt uncomfortable dealing with the JDP. The Undersecretary of Defense Douglas Faith, for example, saw the JDP responsible for the rise of antiAmericanism in Turkey and implicitly indicated his aversion towards them. See Rubin, "A Comedy of Errors: American-Turkish Diplomacy and the Iraq War ".

${ }^{302}$ Cited in Lesser, "Beyond Suspicion: Rethinking Turkey-Us Relations."

303 "Algilamalar," (Uluslararasi Stratejik Arastirmalar Kurumu March 2005).
} 
cadre of liberal intellectuals. In fact, the anti-Americanism was more prominent among the nationalist left and nationalist right as represented by the RPP and the NAP. The transformation of Turkey's domestic affairs since the early 1980s had major implications for the foreign policymaking process. The Turkish public's increasing participation in foreign policy debates through a more diverse media had expanded vastly since the Ozal era, and public opinion became a leading factor in the relationship between Ankara and Washington from 2003 onward.

Turkey's increasingly independent foreign policymaking since 2003- and its active bilateral engagement in the Middle East- sparked discussions on the shift in Turkish foreign policy. ${ }^{304}$ I argue that there are three major domestic processes and two structural ones that shaped and redefined the direction of Turkish foreign policy and its implications on relations with Washington. First, as laid out at length in Chapters IV and $\mathrm{V}$, the change in Turkey's economic, social and political landscape was one of the driving forces in the transformation. The increasing visibility of new actors in the marketplace, schools, media and politics cracked the monotonous political structure of the Kemalist regime and diversified social and political actors. The transformation basically reflected the demands of the Turkish populace that were once marginalized in the periphery. The trials and errors of the emerging political class in the 1990s helped shape the political discourse on the polarization of masses between secularist Kemalists and political

\footnotetext{
${ }^{304}$ See Erhan Dogan, Sivil Toplum Ve Dlş Politika: Yeni Sorunlar, Yeni Aktörler (Baglam, 2006).; Ali F. Demir, Türk Dis Politikasında Liderler: Süreklilik Ve Değişim, Söylem Ve Eylem (Baglam, 2007).; Aydin, Amacimiz Devletin Bekasi: Demokratiklesme Sürecinde Devlet Ve Yurttaslar.; Baskin Oran, Turk Dıs Politikasl, Second ed. (Ankara: Iletisim Yayıncılık, 2001).
} 
Islamists. ${ }^{305}$ The post-modern coup in 1997 and the political demands of the public gave way to a new elite whose members did not define themselves as Islamists but as conservative democrats and which developed a new vocabulary in addressing the demands of a broad coalition of the populace. The JDP's success in formulating domestic and foreign policies that appealed to the larger public was both contemporary and different in its essence. While the JDP leadership communicated with the outside world in a common language in addressing the Turkish policies, ${ }^{306}$ they departed from the traditional foreign policy making that had been largely insular from the public. They successfully, to a certain degree, infused public opinion into foreign policy. ${ }^{307}$ Erdogan's charismatic leadership and Foreign Minister Ahmet Davutoglu's reformulation of Turkish foreign policy received great popular support. Consequently, the JDP took bold initiatives in democratization, economic development, constitutional reforms and the EU accession process. Success in these areas afforded more legitimacy and power to the JDP in elections after 2002. More importantly, the JDP tamed the military tutelage that had had relentless influence on Turkish politics since the 1960s. Indicting a general on charges of plotting to topple the government was unimaginable in the 1990s, but the JDP reforms and firm stance on civilian authority on the military made that a viable possibility in $2009 .^{308}$

\footnotetext{
${ }^{305}$ Belge, Modern Türkiye'de Siyasi Düşünce.

${ }^{306}$ Dursun, Dönüşüm Sürecindeki Türkiye: Aktörler, Alanlar, Sorunlar.

${ }^{307}$ Burhanettin Duran, "Jdp and Foreign Policy as an Agent of Transformation," in The Emergence of a New Turkey: Democracy and the Ak Party, ed. Hakan Yavuz (Salt Lake City: University of Utah Press, 2006).

${ }^{308}$ In June 2009, the Turkish daily Taraf newspaper published army documents of a plan (Operation Cage Action Plan) to defame the ruling Justice and Development Party and Fethullah Gülen, leader of a large
} 
Second, concurrent to the first process of domestic transformation, Turkey's own self perception and the definition of its core interests were redefined due in large part to the change in its domestic scene. ${ }^{309}$ Turkey's relations with Greece, Syria, Russia, Iraq, Armenia, Iran and the United States changed greatly. The 1990s perception of Greece and Syria as enemies was largely abandoned. Even though Greek independence from the Ottoman Empire, the memory of the War of Independence and the Greek invasion of Western Turkey resulted in adversarial relations between Ankara and Athens, dynamic diplomacy since late 1990s did erase the enmity recalling the Alexander Wendt's "cultures of anarchy" 310 classification and started the transition from "enmity" to "rivalry." More interestingly, Turkey's relations with Syria were a good example of Wendt's classification that states could change their relations with others from enmity, rivalry, to friendship or vice versa. Turkey's rapprochement with Syria emerged from 1990s animosity and eventually evolved into friendly relations. Ankara's relations with Washington took a hit when the two countries' "patron-client relationship" of the Cold War era (Chapter II) metamorphosed into Turkey's relative autonomy and independence in conducting its foreign affairs.

Third, it was the rise of new political elite that enabled, channeled and operationalized the course and the parameters of new foreign policies. The pragmatic and activist leadership of Tayyip Erdogan and Abdullah Gul was key in guiding Turkey's

religious and civic movement in Turkey. Eventually, generals wanted to topple the government. More than 100 high-ranking military officers were detained and charged with the crime.

${ }^{309}$ See Mohiaddin Mesbahi, "Eurasia between Russia, Turkey and Iran," in Key Players and Regional Dynamics in Eurasia, ed. Maria R. Freire and Roger E. Kanet (Hampshire: Palgrave Macmillan, 2010).

${ }^{310}$ Wendt, Social Theory of International Politics. 
new orientation. These two leaders' popularity and legitimacy in the eyes of the Turkish public enabled them to incorporate elements of rising global values such as democracy, freedom, market economy and their deeply held religio-conservative values. While strongly supporting Turkey's democratic and market-oriented course, they did not detach themselves from the values they cherished. The third individual, Ahmet Davutoglu, thenChief Foreign Policy Adviser to Erdogan, provided the philosophical background ${ }^{311}$ and practical solutions to Turkey's long-standing problems. What he dubbed the "zeroproblem with neighbors" policy in large part offered solutions to the problems with Greece, Syria, Iraq, Iran and Russia. It even started the engagement with Armenia, but this effort later stalled as a result of domestic constraints in both countries. His policy of lifting visa restrictions for citizens of neighboring nations, paired with his active economic engagement, bore fruit especially with Syria, Iraq, Russia, and Iran as of 2010. These nations reciprocally lifted visa restrictions and increased their bilateral trade volume tremendously. Davutoglu's concept of "strategic depth"312 also offered insight into the transformation of Turkey's foreign policy; he was considered the architect of the JDP's foreign policy initiatives. He argued that Turkey possessed "strategic depth" because of its geostrategic position and unique history. He considered Turkey a "central power"- an idea in direct contrast to Turkey's long-standing position as a "buffer -zone," "flank" and "bridge" in NATO and other western security definitions. In his view,

\footnotetext{
${ }^{311}$ See an interview with Davutoglu, Kerim Balci, "Philosophical Depth: A Scholarly Talk with the Turkish Foreign Minister," Turkish Review 1, no. 1 (Oct.-Nov. 2010). Also see Ahmet Davutoglu, Alternative Paradigms: The Impact of Islamic and Western Weltanschauungs on Political Theory (University Press of America, 1994).

312 Ahmet Davutoglu, Stratejik Derinlik: Türkiye'nin Uluslararası Konumu, 32 ed. (Istanbul: Kure Yayinlari, 2005).
} 
Turkey simultaneously possessed European, Middle Eastern, Mediterranean, Balkan, Caucasian, and African identities as a result of its Ottoman legacy, and therefore could effectively put forth policies concurrently in those regions. Attesting to the centrality of Turkey in these intersecting regions, Davutoglu argued that Turkey should develop its own proactive policies and thereby claim its rightful strategic role. Using the soft power that stemmed from its Ottoman past, Turkey could reinforce economic development, conflict resolution, and the creation of economic interdependence. As Mohiaddin Mesbahi argued, the concept of the "strategic depth" is an "implicit resuscitation of the Ottoman presence and imagination in the Middle East, the Balkans, and its memory as a great imperial power in the international system.”313 Davutoglu's new way of thinking took Turkey from the peripheries of western security and political structures and placed it in the center, making it ground-breaking in design. I think that his reformulation and operationalization of Turkey's foreign policy objectives has the potential of challenging the very nature of Turkish-American relations because many U.S. administrations tended to situate Turkey as a secondary player, a position in which Turkey has been treated as a subject. However, Davutoglu's imagining of modern Turkey envisioned the centrality of Turkey, not as an accessory around the United States. As Mesbahi argued, the new Turkish political elite under the JDP rule reflected and reformulated a "major ideational and temperamental psycho-political change" in Turkey's foreign affairs about "what foreign policy actually is, what its functions and purposes are, and what Turkey actually means to the world polity; a change that only a new elite,... with a different self-

\footnotetext{
${ }^{313}$ Mesbahi, "Eurasia between Russia, Turkey and Iran.", p. 173
} 
perception could introduce and construct." ${ }^{314}$ Given the repeated support of Turkish electorate in successive elections to this new elite, the consolidation of this transformation in both domestic and foreign policy arenas seems to go further in the near future.

It is important, however, to note that the promise and future of the Davutoglu Doctrine in terms of projecting Turkish soft power in the region and solving problems with Armenia and Iraq have yet to be seen. Especially important is the question of how and to what extent Turkey can balance engagement with neighboring nations and the ambitions of global powers like the United States. The question becomes clearer when we incorporate the future of U.S.-Iran relations. The U.S. push for implementing an embargo against Iran had the possibility to harm Turkey. Even though Turkey remains opposed to Iran's nuclear ambitions, it knew that Iran was the major source of its natural gas and a vital trade partner. Additionally, both countries shared the goal of containing Kurdish separatism and neither had territorial ambitions against each other. If an Iraq War-like escalation would emerge from the U.S., Turkey would have a difficult time formulating properly balanced policies.

Apart from these three domestic processes as argued above, there are two structural processes that helped shape the transformation of Turkish foreign policy. First was the European Union membership process. Turkey's EU bid was one of the driving forces in pushing for economic, political and social liberalization since 1960s. It became more visible when both Ozal in the 1980s and Erdogan in the 2000s used the EU membership prospect to push for political reforms that could not garner a broad coalition

\footnotetext{
${ }^{314}$ Ibid.
} 
of center right, center left, and liberal constituencies. Europeanization like the role of religion and nationalism was one of the major veins in Turkish political vocabulary that had transformative effects in redefining political language in Turkey. The JDP's push for democratic reforms and its efforts to tame the military's role in politics opened a new chapter with the EU. In October 2005, Turkey started accession talks with EU, an openended process of indefinite duration. The second transformative structural change was the post-Cold War environment as extensively discussed throughout the dissertation.

As I argued in Chapters I, IV and V, the rise of nationalism and political Islam among the Turkish constituency in the 1990s, in part, challenged U.S. involvement in the region and indicated the early stages of agency's new identity formation. Even though structural factors mostly determined the nature of relations between Ankara and Washington, however, Ankara's refusal to station 62,000 American troops on Turkish soil for Iraqi invasion, and a more assertive Turkish foreign policy in the Middle East, crystallized the role of agency, namely the new Turkey. It was clearly a moment that agency asserted itself against the structural compellence. It was the transformation of Turkey's domestic constituency that allowed for the institution of a policy that many saw as unreasonable given the ascendancy of American unilateralism. In conclusion, the redefinition of Turkey's self-identity and the transformation of Turkish interests due to domestic processes and universal trends refined its policies with the United States and interactions between Ankara and Washington that would define the norms of future encounters. 


\section{CHAPTER VI: CONCLUSION}

My dissertation examined the contours of Turkish-American foreign relations in the post-Cold War era from 1990 to 2005 . While providing an interpretive analysis, I highlighted elements of continuity and change and of convergence and divergence in the relationship between Ankara and Washington. The primary purpose was to demonstrate the historical evolution of Turkish-American foreign relations in the post-Cold War era, recognizing that the "Kurdish question" was one of prime driving forces in defining the nature and scope of the relationship, especially in the aftermath of the Gulf War. Turkey's encounter with its Kurdish problem at home intertwined with the emergence of an autonomous Kurdish authority in northern Iraq after the Gulf War that left a political vacuum in the region. The main argument of this dissertation was that since 1991, the Kurdish question was the central element in shaping and redefining the TurkishAmerican relations and that Ankara's relations with Washington have been conducted in a triangulation that the Kurdish question affected in one form or another.

While Chapter I provided the literature review and theoretical discussions on the agent-structure debate, it also put forth the foundation of my dissertation's main assertions. Chapter II offered a survey of Turkish-American relations from 1800 to 1990 in order to help explain the intricacies of the complex history behind Turkish-American relations in later periods. The main motive to include such a chapter was that, in fact, the two nations' encounters over centuries laid the groundwork for present-day engagement. Early encounters between the U.S. and the Ottoman Empire were based on trade and diplomatic relations. In later decades, the relationship was diversified and became more complicated as many protestant missionaries from the U.S. came to the Ottoman lands to 
evangelize mainly Orthodox Christian minorities to Protestantism in the Ottoman state, primarily by opening schools. The relationship between Washington and the Sublime Porte was further severed when mass killings of Armenians under the Ottoman rule took place in 1915 and that the President Wilson's progressive agenda of advocating selfdetermination clearly posed serious challenges for decaying multi-ethnic Ottoman state. At the outset of young Turkish Republic, Ataturk did not want Turkey to be aligned with any major western power because of the painful memory of the War of Independence. His ambitious agenda of modernization by taking drastic domestic measures in the areas of politics, law, economy, and culture also did not let him invest his political and economic capital in foreign affairs. In spite of Ataturk's insistence on charting a nonaligned and independent foreign policy during the interwar period, the new leadership under President Inonu came to a realization that the prospect for Turkey's future should closely be tied to emerging post-World War II western security institutions. Otherwise, Turkey's independence would severely be jeopardized by the imminent threat of Soviet invasion. Turkey had no option but to abandon its long-preferred policy of non-alignment during the interwar period. It aligned itself with the Western powers and especially the United States. I argued that the World War II and its aftermath was a watershed moment that bolstered Turkey's "western vocation." Turkish political elite argued for the first time that Turkey is geographically significant to Western interests especially to the United States since the Soviets could eventually access the Middle East by first invading Turkey. The Turkish argument iterated that Turkey is a key country and that giving in to Soviet pressure would allow the Soviets unmitigated influence in the Middle East and Mediterranean. This argument of the "geographic/geostrategic significance of Turkey" 
has since been a useful staple in Turkish foreign policy, enduring despite the changing nature of enemies in the decades to come. I argued in Chapter II that Turkey's claim to a "strategic position" in the heart of three continents of Asia, Europe, and Africa, has been the lifeline of the country in countering major national and international challenges since the end of World War II. Consequently, Turkey was included in the U.S. strategic calculations during the Cold War era by means of the Truman Doctrine and the Marshall Plan, providing monetary and security assistance to Turkey. Ankara's inclusion in NATO in 1952 completed its integration in the western security apparatus against the Soviet threats. I, therefore, argued that Turkey's foreign policy was largely pegged into the U.S. foreign policy calculations despite occasional mishaps like the issue of Cyprus in mid1960s and 1970s.

To grasp the underlying themes and the narratives in the relations between Ankara and Washington in the post-Cold War era, one needs to see four broadly defined transformative periods in Turkey's foreign policy since 1923. The first one took place between 1923 and 1945 when the Turkish republic was established as a country whose identity was based on a Turkish nation-state ideal on the republican premise. Even though the founding leader Ataturk has defined young Turkey's course forward as "western oriented," he insisted on following a strictly non-aligned foreign policy in that period since the painful memory of western imperial ambitions on Turkish soil in the early $20^{\text {th }}$ century kept Turkey away from alliance formations with the West. It should also be noted that the consolidation of Turkey's new order necessitated more focus on domestic affairs rather than foreign policy. The implementation of radical modernization in Turkish 
politics and society did not, by and large, let Ataturk and the new elite engage in foreign affairs.

The second is the exclusive integration of Turkey into western security and political institutions during the Cold War era (1945-1990), largely a result of the imminent threat of Soviet expansion. Turkey mostly pegged its foreign policy orientation to that of the United States and sought economic and military aid from the U.S. to reinforce its defense against the Soviet Union. The Turkish elite also developed a compelling argument that Turkey held a strategic position at the intersection of Europe and Asia and had served as a bulwark of NATO's southeastern flank. Despite occasional disagreements between two allies like the 1974 U.S. arms embargo to Turkey, the relationship reflected the importance of structural factors in determining Ankara's positions towards Washington and could be categorized as "patron-client relationship."

The third period (1990-2003) is that of the post-Cold War environment, which signified the demise of Soviet Union and the threat therefrom, but also brought a wide array of challenges and opportunities for Turkish foreign policy making. During this period, Turkey had to face growing threats of instability in the neighboring regions like the Middle East, the Caucasus, and the Balkans. The advent of the Gulf War and strong Turkish involvement on the side of the U.S., as laid out in Chapter III, became a defining factor in Ankara's relations with Washington. It left a lasting impact on the identification and redefinition of Turkey's domestic and foreign affairs, especially with the United States. The Kurdish question both at home and in the neighborhood continued to be one of the top agenda items for Turkey throughout the 1990s. The increasing intensity of PKK attacks in Turkey, coupled with the ever-pressing reality of an autonomous Kurdish 
authority despite the in-fighting among the Kurdish factions in northern Iraq, resulted in more aggressive Turkish measures, especially from the military. Some of Turkey's antiPKK actions in southeastern Turkey led to widespread human rights violations among Turkey's Kurdish citizens. The United States and European nations repeatedly cautioned Turkey on its treatment of Kurds, thereby straining their relationships with Turkey. While the U.S.'s strategic outlook on Turkey always trumped concerns like human rights violations, Europeans conversely pressed Turkey harder. They were bolstered by their proximity to Turkey, a vibrant Kurdish diaspora in Europe, and the EU's commitment to human rights issues. Since the mid-1990s, Turkey's domestic affairs have become messier. As discussed in Chapter IV, weak coalition governments could not produce stability in economy and politics and thereby incited a greater role for the Turkish military in Turkish politics. In addition to instability in domestic affairs, Turkey's relations with Greece and Syria were severely strained and both came close to the brink of war with Turkey. On the other hand, the rapprochement between Turkey and Israel and passionate U.S. support for Turkey's bid for European Union membership, resulted in a new phase in the Turkish-American relations: a strategic partnership. However, this partnership should be understood in a context whereby the United States perceived Turkey as an indispensible ally that greatly mattered to many vital American strategic interests. As former U.S. Ambassador Mark Parris put it "Turkey is important to the United States of America... because of its influence on a remarkably broad range of American interests: from bringing peace to Bosnia to bringing peace to the Middle East; from containing Iraq and Iran to opening up the New Independent States of central Asia; from solving the problem of Cyprus to normalizing the situation in the Caucasus; from 
combating regional terrorism to shutting down drug trafficking. Turkey is important to us as a paradigm: it is a large, predominantly Muslim country in a troubled region with a tradition of secular governance and expanding democracy, with a 70-year commitment to integration and cooperation with the West, and with a 50-year record of standing shoulder to shoulder with American forces from Korea to the Gulf War to Somalia to Bosnia."

The fourth period signaled the beginning of a new era of activism in Turkish foreign policy, which started roughly in 2003 with the Turkish rejection of U.S. troops being stationed on Turkish soil to overthrow Saddam regime in Iraq. The U.S. assumed that Turkey, an important partner during the Gulf War, would lend its support again. The Bush administration underestimated the grueling impact of the economic implications on Turkey because of the UN sanctions against Iraq, which was a major trading partner for Turkey before the Gulf War. More importantly, Washington did not adequately comprehend the far-reaching consequences of the Kurdish question on Turkey's elite and the public due in large part to the U.S. policies in northern Iraq. Repeated surveys revealed that over $90 \%$ of the Turkish populace opposed the U.S. invasion and Turkish involvement in the war efforts. As a result, on March $1^{\text {st }}, 2003$, the Turkish parliament rejected the resolution that would allow American troops in Turkish soils to topple Saddam's regime. In Chapter V, I argued that this was a watershed moment between Ankara and Washington in that Turkey rejected the primacy and unilateralism of the U.S. against the Iraqi invasion. Looking from the agent-structure debate in international

\footnotetext{
${ }^{315}$ Parris, "Ambassador-Designate Mark Parris Statement at Confirmation Hearing."
} 
relations, the prevailing perspective was that international structure ${ }^{316}$ would require Turkey to let the U.S. troops on its soil despite overwhelming opposition from the Turkish public. I put forth that systemic factors primarily prevailed in the early years of the post-Cold War Turkish-American relations, as had been the case during the Cold War era. However, the Turkish parliament's rejection of the deployment of the U.S. troops in Turkey for the invasion of Iraq in 2003 could not be explained by the primacy of distribution of capabilities in the system. Instead, the role of identity, ideology, and norms, and the socialization of agency through interaction and language, must be considered. As many constructivists argue, interests and identities of actors are shaped and redefined in an interactive process in the international system. In fact they are constituted subjectively. By bringing both material and ideational aspects into the picture, one can see how dynamic interaction of these elements shapes and redefines one's identity and interests. It should also be noted that the JDP assertive new foreign policy reflected the growing role of the Turkish populace in foreign policy making. While keeping its western orientation, Turkey began to assert itself as an independent and selfconfident actor who could heavily invest in the Middle Eastern affairs that Turkey ignored for a long-period of time. It should also be noted that this activism in foreign policy was a reflection of a wider transformation in Turkey's own self-perception and the definition of its core interests.

To analyze the identity and interest formation in Turkey, I argued that Turgut Ozal's liberalization efforts in politics and economy between 1983 and 1993 paved the

\footnotetext{
${ }^{316}$ By the term "structure," I mean the Waltzian understanding of the international structure of international relations. See the discussion in Chapter 1. Also see Waltz, Theory of International Politics.
} 
way for the emergence of new political and economic spaces that were filled largely by the Anatolian conservative populace. They benefitted from economic and political openings in the early 1980s and became competitive in education and business by the mid 1990s. The rising "Anatolian tigers" and the increasing visibility of conservative Muslims in public spaces, especially in education, media and business, gave way for the emergence of a new socio-political elite that engaged with the center through active political participation. The increasing visibility of new actors in the marketplace, schools, media and politics cracked the monotonous political structure of the Kemalist regime and diversified social and political actors. The transformation in domestic and foreign affairs basically reflected the demands of the Turkish populace that were once marginalized in the periphery. The JDP's ascension to power in 2002 magnified the growing role of the periphery in the foreign policy making arena and also reflected changes in Turkey's own self perception and the definition of its core interests. Ankara's changes of heart in its relations with Greece and Syria, both of which were once considered enemies, serves as a good example of the transformation of Turkey's foreign policy orientation. When it comes to its relations with the U.S, however, Turkey's new elite (with strong backing from the Turkish public) charted an independent orientation that had been unimaginable for more than 50 years. The JDP leadership, especially Prime Minister Tayyip Erdogan and Foreign Minister Ahmet Davutoglu, and President Abdullah Gul successfully incorporated in their government elements of rising global values such as democracy, freedom, market economy and their deeply held religio-conservative values. While strongly supporting Turkey's democratic and market-oriented course, they did not detach themselves from the values they cherished. Especially, Davutoglu's philosophical and 
practical approaches to foreign policy enabled Turkey to chart a relatively independent foreign policy orientation towards the United States. He argued that Turkey a "central power"- an idea in direct contrast to Turkey's long-standing position as a "buffer-zone," "flank" and "bridge" in NATO and other western security definitions. Attesting to the centrality of Turkey, Davutoglu argued that Turkey should develop its own proactive policies and thereby claim its rightful strategic role. His new way of thinking took Turkey from the peripheries of western security and political structures and placed it in the center, making it ground-breaking in design. I argued that his reformulation and operationalization of Turkey's foreign policy objectives has the potential of challenging the very nature of Turkish-American relations because many US administrations tended to situate Turkey as a secondary player, a position in which Turkey has been treated as a subject. However, Davutoglu's imagining of modern Turkey envisioned the centrality of Turkey, not as an accessory around the United States.

An activist Turkish foreign policy in the Middle East, Africa, the Caucasus, the Balkans, the EU and Central Asia would encounter the U.S. every step of the way since Turkey's engagement in these regions would always intersect with Washington's vital strategic interests. While convergence of these engagements would be welcomed by both, a divergence of interests could create serious friction between the two that had the potential to disturb the strategic alliance. For example, the future of Iran's pursuit of nuclear weapons and the U.S. escalation against it would have the potential of jeopardizing the relations between the U.S. and Turkey. Moreover, Turkey's increasing critique of Israel and possible escalation in the Iran issue would have serious repercussions on the Turkish-American relations in coming years. While my dissertation 
provided a compelling historical analysis of Ankara's relations with Washington between 1990 and 2005 by highlighting the elements of continuity and change, future research should focus on the question of how and to what extent Turkey would maintain its ambitious foreign policy objective of "zero problems with neighbors" while handling conflicting interests among regional and global powers. More importantly, Turkish public opinion towards the United States dropped significantly in the last eight years due in large part to the Iraqi War of 2003. Turks also became less enthusiastic about the EU membership given that the public support dropped from $73 \%$ in 2004 to $40 \%$ in 2010 . Since the public opinion became an important variable in shaping the Turkish foreign policy in the last decade, further sources of friction and divergences of policy orientations between Turkey and the west, especially the U.S., would occur. Therefore, Ankara's relations with Washington are no longer as predictable as had been the case in previous decades. 


\section{BIBLIOGRAPHY}

"28 Subat Bitmedi ". Milliyet September 4, 1999.

"Abd Apo'yu Teslim Etti Çünkü Bağımsız Kürt Devletine Engeldi (America Delivered Ocalan Because He Was an Impediment to Independent Kurdish State)." Vatan October 15, 2008.

"Aftermath; the Bush Doctrine." New York Times April 13, 2003.

"Ak Parti Programı." Ankara, 2001.

"Akp'de Tezkere Sikıntisi ". Hurriyet February 22, 2003.

"Algilamalar." Uluslararasi Stratejik Arastirmalar Kurumu March 2005.

"A National Security Strategy for a New Century." edited by The White House. Washington, DC, October 1998.

"A National Security Strategy of Engagement and Enlargement." edited by The White House. Washington, DC, February 1996.

Abramowitz, Morton. Turkey's Transformation and American Policy. Edited by Morton Abramowitz. New York: Century Foundation Press, 2000.

Adams, T. W. "The American Concern in Cyprus." Annals of the American Academy of Political and Social Science, no. 401 (May 1972): 96-97.

Adler, Emanuel. "Seizing the Middle Ground: Constructivism in World Politics." European Journal of International Relations 3, no. 3 (1997): 319-63.

Ahmad, Feroz. Demokrasi Surecinde Turkiye (1945-1980). Translated by Ahmet Fethi. Istanbul: Hil Yayinlari, 1994.

- The Turkish Experiment in Democracy, 1950-1975. Boulder, CO: Westview Press, London, 1977.

Akçapar, Burak. Turkey's New European Era: Foreign Policy on the Road to Eu Membership. Lanham, MD: Rowman \& Littlefield Publishers, 2006.

Akdevelioğlu, Baskın Oran and Atay. Turk Dis Politikasi: Kurtuluş Savaşından Bugune Olgular, Belgeler, Yorumlar: Iletisim Yayinlari, 2004.

Akdogan, Y. Siyasal Islam: Refah Partisi'nin Anatomisi: Sehir Yayinlari, 2000.

Akdoğan, Yalçın. Ak Parti Ve Muhafazakâr Demokrasi: Alfa Yayinlari, 2004. 
Akşin, Aptülahat. Atatürk'ün Dis Politika Ilkeleri Ve Diplomasisi: Turk Tarih Kurumu Basimevi, 1991.

Akyuz, Abdullah. "Us-Turkish Economic Relations on the Outset of the 21 st Century." Washington, DC: Turkish Industrialists' and Businessmen's Association, October 2000 .

Albayrak, Sadik. Turkiye'de Islamciligin Dogusu. Istanbul: Risale, 1989.

Alkan, Turker. "Postmodern Bir Askerî Müdahale." Radikal June 13, 1997.

Alpman, Nazim. "Bizim De Bir Falkland'imiz Oldu " Milliyet January 29, 1996.

Altan, Mehmet. Darbelerin Ekonomisi: Afa Yayinlari, 1990.

Altunisik, Meliha. "The Turkish-Israeli Rapprochement in the Post-Cold War Era." Middle Eastern Studies 36, no. 2 (April 2000): 172-91.

_. Türkiye Ve Ortadoğu: Tarih, Kimlik, Güvenlik. Ankara: Boyut Kitaplari, 1999.

Angel Rabasa, Stephen Larabee The Rise of Political Islam in Turkey. Santa Monica, CA: RAND, 2008.

Aral, Berdal. "Dispensing with Tradition? Turkish Politics and International Society During the Özal Decade, 1983-93." Middle Eastern Studies 37, no. 1 (2001): 7288.

Aras, Bulent. Türkiye Ve Ortadoğu: Türk Dış Politikasının Toplumsal Kökenleri: QMatris, 2003.

Arikan, Harun. Turkey and the EU: An Awkward Candidate for EU Membership? Burlington, VT: Ashgate, 2006.

Armaoglu, Fahir. 20. Yüzyll Siyasi Tarihi, 1914-1980. Istanbul: Is Bankası Kültür Yayınları, 1984.

_. "Ataturk Doneminde Turk-Amerikan Iliskileri." Ataturk Arastirma Merkezi Dergisi 38, no. 1 (1997).

—. Belgelerle Turk-Amerikan Munasebetleri. Ankara: Turk Tarih Kurumu, 1991.

Arvanitopoulos, Constantine. Turkey's Accession to the European Union: An Unusual Candidacy. Edited by Constantine Arvanitopoulos: Springer, 2009.

Ataov, Turkaya. Amerika, Nato Ve Turkiye. Ankara: Ileri Yayinlari, 1969.

Atay, Falih Rifki. Cankaya. Istanbul: Yeni Gun Haber Ajansi, 1999. 
Aydin, Mustafa. "Determinants of Turkish Foreign Policy: Changing Patterns and Conjunctures during the Cold War." Middle Eastern Studies 36, no. 1 (2000): 103-39.

_ . "Determinants of Turkish Foreign Policy: Historical Framework and Traditional Inputs." Middle Eastern Studies 35, no. 4 (1999): 152-86.

—. Turkish Foreign Policy during the Gulf War of 1990-1991. Cairo, Egypt: American University in Cairo Press, 1998.

Aydın, Mustafa, and Çağnı Erhan. Turkish-American Relations: Past, Present and Future. London; New York: Routledge, 2004.

Aydin, Suavi. Amacimiz Devletin Bekasi: Demokratiklesme Sürecinde Devlet Ve Yurttaslar. Istanbul: TESEV, 2006.

Aykan, Mahmut B. Soğuk Savaş Sonrası Dönemi Ortadoğu'sunda Türkiye'nin İsrail'e Karşı Politikası, 1991-1998. Istanbul: Yeditepe Universitesi, 2000.

__. "Turkey's Policy in Northern Iraq, 1991-95." Middle Eastern Studies 32, no. 4 (1996): 343-66.

—. Turkiye'nin Kuveyt Krizi (1990-91) Politikası. Ankara: Dis Politika Enstitusu Yayinlari, 1998.

Aykol, Huseyin. Ortadoğu Denkleminde İsrail-Türkiye Ilişskileri: Oteki Yayinevi, 1998.

Bagci, Huseyin. Turk Dis Politikasinda 1950'li Yıllar. Ankara: METU Press, 2001.

Bahcheli, Tozun. Greek-Turkish Relations since 1955. Boulder: Westview Press, 1990.

Bal, Idris. 21. Yüzyılda Türk Dış Politikası. Ankara: Global Arastirmalar Merkezi, 2006.

Balci, Kerim. "Philosophical Depth: A Scholarly Talk with the Turkish Foreign Minister." Turkish Review 1, no. 1 (Oct.-Nov. 2010): 58-67.

Barkey, Henri J. Reluctant Neighbor: Turkey's Role in the Middle East. Washington, D.C.: United States Institute of Peace Press, 1996.

Barkey, Henri J., and Graham E. Fuller. Turkey's Kurdish Question. Lanham, MD: Rowman \& Littlefield Publishers, 1998.

Barry Buzan, Ole Waever, Jaap de Wilde. Security: A New Framework for Analysis. Boulder, CO: Lynne Rienner Publishers, 1998.

Barry M. Rubin, Kemal Kirisci Turkey in World Politics: An Emerging Multiregional Power. Boulder, CO: Lynne Rienner Publishers, 2001. 
Bartholomew, Alan Alfred. "Tarsus American School, 1888-1988: The Evolution of a Missionary Institution in Turkey." Dissertation, Bryn Mawr College, 1989.

Bayramoglu, Ali. 28 Şubat: Bir Müdahalenin Güncesi. Istanbul: Birey, 2001.

Behramoglu, Namik. Türkiye Amerikan Ilişkileri: Demokrat Parti Dönemi: Yar Yayinlari, 1973.

Belge, Murat. Modern Türkiye'de Siyasi Düşünce. Vol. 7: Iletisim Yayinlari, 2005.

—. Türkler Ve Kürtler, Nereden Nereye? Ankara: Birikim Yayinlari, 1995.

Bengio, Ofra. "Iraq." In Middle East Contemporary Survey, Volume 21, edited by Bruce Maddy-Weitzman. Boulder, CO: Westview Press, 2000.

Birand, Mehmet A. Shirts of Steel: An Anatomy of the Turkish Armed Forces. London: I. B. Tauris, 1991.

—_. " Türkiye, Abd’ye "Hayır" Diyemez." Hurriyet February 12, 2002.

Bolukbasi, Suha. "Behind the Turkish-Israeli Alliance: A Turkish View." Journal of Palestine Studies 29, no. 1 (1999): 21-35.

—. The Superpowers and the Third World: Turkish-American Relations and Cyprus. Lanham, MD: University Press of America, 1988.

Bora, Tanil and Kemal Can. Devlet, Ocak, Dergah -12 Eylul'den 1990'lara Ulkucu Hareket. Istanbul: Iletisim Yayinlari, 2000.

Bostanoglu, Burcu. Turkiye-Abd Iliskilerinin Politikasi. 2 ed. Ankara: Imge Kitabevi Yayinlari, 2008.

Brown, James. "The Turkish Imbroglio: Its Kurds." Annals of the American Academy of Political and Social Science, no. 541 (1995): 116-29.

Bush, George W. "Transcript of President Bush's Prayer Service Remarks: National Day of Prayer and Remembrance for the Victims of the Terrorist Attacks on September 11, 2001." edited by The White House. Washington, DC, September $14,2001$.

Büyükkarcı, Süleyman. Türkiye'de Amerikan Okullart: Mikro Basim-Yayim-Dagitim, 2002.

Byman, Daniel. "After the Storm: U.S. Policy toward Iraq since 1991." Political Science Quarterly 115, no. 4 (2000-2001): 493-516. 
Çağaptay, Soner. Islam, Secularism, and Nationalism in Modern Turkey: Who Is a Turk? New York: Routledge, 2006.

Cakir, Rusen. Türkiye'nin Kürt Sorunu. Ankara: Metis, 2004.

Cakmak, Haydar. Turk Dis Politikası, 1919-2008. Ankara: Platin, 2008.

Çandar, Cengiz. "The Kurdish Question: The Reasons and Fortunes of the 'Opening'." Insight Turkey 11, no. 4 (2009): 13-19.

_. "Turkey's "Soft Power" Strategy: A New Vision for a Multi-Polar World." Ankara: SETA, 2009.

Cavdar, Tevfik. Turkiye'nin Demokrasi Tarihi. Second ed. Ankara: Imge Kitabevi, 2002.

—. Türkiye'nin Demokrasi Tarihi:1950'den Günümüze. Ankara: Imge Kitabevi, 2008.

Çelik, Yasemin. Contemporary Turkish Foreign Policy. Westport, Conn.: Praeger, 1999.

Cemal, Hasan. Kurtler. Istanbul: Dogan Kitap, 2003.

—. Özal Hikayesi. Yenisehir, Ankara: Bilgi Yayinevi, 1989.

Cengiz Candar, and Graham Fuller. "Grand Geopolitics for a New Turkey." Mediterranean Quarterly 12, no. 1 (Winter 2001): 22-38.

Cevizoglu, Hulki. Körfez Savaşı Ve Özal Diplomasisi: Form Yayinlari, 1991.

Checkel, Jeffrey. "International Norms and Domestic Politics: Bridging the RationalistConstructivist Divide." European Journal of International Relations 3, no. 4 (1997): 473-95.

Cigdem, Ahmet, ed. Muhafazakârlık. Istanbul: Iletisim Yayinlari, 2004.

"Ciller Kaddafi'ye Sert Cikti: Haddini Bil." Zaman October 8, 1996.

"Clinton'in Ege Endisesi." Milliyet January 29, 1996.

"Congressional Presentation for Foreign Operations for FY 1999." edited by The United States Department of State. Washington, DC, 1999.

"Congressional Presentation for Foreign Operations, FY 1990-2000." edited by United States Department of State, 2000.

"Country Commercial Guide: Turkey Fiscal Year 1999." edited by The United States Department of State. Washington, DC, August 7, 1998. 
Congar, Yasemin. "Abd, Pkk’ya Artik Farkli Bakiyor." Milliyet April 10, 1995.

Dagi, Zaynep. Doğu'dan Batı'ya Dış Politika: Ak Parti'li Yıllar. Ankara: Orion Yayinevi, 2006.

Davutoglu, Ahmet. Alternative Paradigms: The Impact of Islamic and Western Weltanschauungs on Political Theory: University Press of America, 1994.

—. Stratejik Derinlik: Türkiye'nin Uluslararası Konuтu. 32 ed. Istanbul: Kure Yayinlari, 2005.

Demir, Ali F. Türk Dis Politikasında Liderler: Süreklilik Ve Değişim, Söylem Ve Eylem: Baglam, 2007.

—. Türk Dış Politikasında Liderler: Süreklilik Ve Değişim, Söylem Ve Eylem: Baglam, 2007.

Denktas, Rauf. The Cyprus Triangle. London: Allen \& Unwin 1982.

DeNovo, John A. "A Railroad for Turkey: The Chester Project, 1908-1913." The Business History Review 33, no. 3 (1959): 300-29.

Dinçer, Osman B. and Habibe Özdal and Hacali Necefoğlu. Yeni Dönemde Turk Dis Politikası, Uluslararası 4. Türk Dış Politikası Sempozyumu Tebliğleri. Ankara: USAK, 2010.

Dogan, Erhan. Sivil Toplum Ve Dış Politika: Yeni Sorunlar, Yeni Aktörler: Baglam, 2006.

Donat, Yavuz. Cumhuriyetin Kara Kutusu: Süleyman Demirel Anlatiyor. 2 ed. Istanbul: Merkez Kitapcilik ve Yayincilik, 2005.

Duman, Dogan. Demokrasi Surecinde Turkiye'de Islamcllk. Izmir: Dokuz Eylul Yayınlar1, 1997.

Duran, Burhanettin. "Jdp and Foreign Policy as an Agent of Transformation." In The Emergence of a New Turkey: Democracy and the Ak Party, edited by Hakan Yavuz. Salt Lake City: University of Utah Press, 2006.

Dursun, Davut and Burhanettin Duran and Hamza Al. Dönüşüm Sürecindeki Türkiye: Aktörler, Alanlar, Sorunlar. Ankara: Alfa Yayinlari, 2007.

Duzel, Nese. Taraf 24 November 2008.

__. "Mumcu, Apo'nun Devletteki Baglantisi Buldu (Mumcu Found State's Connection with Apo)." Radikal 29 May 2005. 
Erhan, Cagri. Beyaz Savaş:: Türk-Amerikan Ilişskilerinde Afyon Sorunu. Ankara: Bilgi Yayinevi, 1996.

Erlanger, Steven. "New Turkish Chief's Muslim Tour Stirs Us Worry." New York Times August 10, 1996.

Esra LaGro, Knud Erik Jørgensen. Turkey and the European Union: Prospects for a Difficult Encounter: Palgrave Macmillan, 2007.

Fendoglu, Tahsin. Osmanll-Amerika Ilişkileri, 1786-1929: Beyan, 2002.

"Foreign Military Sales, Foreign Military Construction Sales and Military Assistance Facts." edited by Defense Security Assistance Agency, 1998.

"The Full Text of President Bush's Address to Joint Session of Congress." http://www.foxnews.com/story/0,2933,34782,00.html.

Fuller, Graham E. The New Turkish Republic: Turkey as a Pivotal State in the Muslim World. Washington, DC: United States Institute of Peace Press, 2008.

Goffman, Carolyn Mccue. "More Than the Conversion of Souls': Rhetoric and Ideology at the American College for Girls in Istanbul, 1871-1923." Dissertation, Ball State University, 2002.

Gordon, Leland J. "Turkish-American Treaty Relations." American Political Science Review 22, no. 3 (1928): 711-21.

Gordon, Philip H., and Omer Taspinar. Winning Turkey: How America, Europe, and Turkey Can Revive a Fading Partnership. Washington, DC: Brookings Institution Press, 2008.

Gozen, Ramazan. Amerikan Kiskacinda Dis Politika: Korfez Savasi, Turgut Ozal Ve Sonrasi. Istanbul: Liberte, 2000.

Gulecyuz, Kazim. Islam'da Siyaset Dusuncesi: Derleme: Insan Yayinlari, 1995.

"Guneydogu Sorununa GAP Cozumu." Milliyet November 10, 1994.

Gunter, Michael M. "The Continuing Kurdish Problem in Turkey after Ocalan's Capture." Third World Quarterly 21, no. 5 (2000): 849-69.

_. "A de facto Kurdish State in Northern Iraq." Third World Quarterly 14, no. 2 (1993): 295-319.

_. "United States Foreign Policy toward the Kurds." In The Kurdish Question in U.S. Foreign Policy: A Documentary Sourcebook, edited by Lokman I. Meho: Praeger Publishers, 2004. 
Hale, William. "Turkey, the Middle East and the Gulf Crisis." International Affairs 68, no. 4 (1992): 679-92.

—. Turkish Foreign Policy, 1774-2000. London ; Portland, OR: Frank Cass, 2000.

Harris, George. Troubled Alliance: Turkish-American Problems in Historical

Perspective, 1945-1971, Washington: American Enterprise Institute for Public Policy Research, 1972.

Hart, Parker T. Two Nato Allies at the Threshold of War: Cyprus: A Firsthand Account of Crisis Management, 1965-1968. Durham: Duke University Press, 1990.

Heper, Metin. Ismet Inönü: The Making of a Turkish Statesman. New York: Brill, 1998.

- The State and Kurds in Turkey: The Question of Assimilation. Hampshire: Palgrave Macmillan, 2007.

—. State Tradition in Turkey. North Humberside: Eothen Press, 1985.

Heper, Metin, Ali Kazancigil, and Bert A. Rockman. Institutions and Democratic Statecraft. Boulder, Colo.: Westview Press, 1997.

Heper, Metin, and Sabri Sayari. Political Leaders and Democracy in Turkey. Lanham, Md.: Lexington Books, 2002.

"Hoca'yi Terleten Diyalog." Milliyet October 7, 1996.

Imset, Ismet G. Pkk: Ayrıllkçı Şiddetin 20 Yllı, 1973-1992. Ankara: Turkish Daily News Yayinlari, 1993.

Inaç, Hüsamettin. Avrupa Birligi'ne Entegrasyon Sürecinde Türkiye'nin Kimlik Problemleri. Ankara: Adres Yayinlari, 2005.

İnan, Kamran. Dis Politika. Ankara: Otuken Nesriyat, 1993.

Inbar, Efrahim. "Regional Implications of the Israeli-Turkish Strategic Partnership." Middle East Review of International Affairs 5, no. 2 (Summer 2001).

Inonu, Ismet and Lyndon B. Johnson. "President Johnson and Prime Minister Inonu: Correspondence between President Johnson and Prime Minister Inonu, June 1964, as Released by the White House, January 15, 1966." Middle East Journal 20, no. 3 (Summer 1966).

Johnson, Hugh Gray. "The American Schools in the Republic of Turkey, 1923-1933: A Case Study of Missionary Problems in International Relations." Dissertation, The American University, 1975. 
Kara, Ismail. Turkiye'de Islamcilik Dusuncesi: Metinler, Kisiler. Istanbul: Risale, 1987.

Karaalioglu, Mustafa. Hilal Ve Ampul: Fazilet'ten, Saadet Ve Ak Parti'ye Bir Hareketin Öyküsü: Bakis, 2001.

Karpat, Kemal. Turk Demokrasi Tarihi - Siyasal, Ekonomik, Kulturel Temeller. Istanbul: Afa Yayınc1lik, 1996.

_. "Political Developments in Turkey, 1950-70." Middle Eastern Studies 8, no. 3 (1972): 349-75.

Kayar, Mustafa. Türk - Amerikan Ilişkilerinde Irak Sorunu: IQ Kultursanat Yayincilik, 2003.

Kazgan, Gulten. Tanzimattan 21. Yuzyıla Turkiye Ekonomisi. Istanbul: Bilgi Universitesi Yayınları, 2002.

Kemal Dervis and Serhan Asker and Isik, Yusuf Krizden Çikis Ve Çagdas Sosyal Demokrasi: Kemal Dervis Anlatiyor. 2 ed. Istanbul: Dogan Kitapcilik, 2006.

Kemal Kirisci, Nathalie Tocci, and Joshua Walker. "Turkey's Transatlantic Value." New York: German Marshall Fund of the United States, 2010.

Kennedy, Paul. The Rise and Fall of the Great Powers: Economic Change and Military Conflict from 1500-2000. New York: Random House, 1987.

Keyman, Fuat. Remaking Turkey: Globalization, Alternative Modernities, and Democracy. Lanham, MD: Lexington Books, 2007.

—. "Modernization, Globalization and Democratization in Turkey: The AKP Experience and Its Limits." Constelleations 17, no. 2 (June 2010): 317-27.

Khalilzad, Zalmay. "Why the West Needs Turkey." Wall Street Journal December 22, 1998.

Kibaroglu, Mustafa. "Clash of Interest over Northern Iraq Drives Turkish-Israeli Alliance to a Crossroads." Middle East Journal 59, no. 2 (Spring 2005).

Kılıç, Şengün and Mehtap Yücel, Murat İnceoğlu. Biz Ve Onlar: Türkiye'de Etnik Ayrımcllı : Araştırma-Röportaj. Ankara: Metis 1992.

Kinzer, Stephen. "Meeting Us Envoy, Turkish Premier Takes Pro-Arab Stance" New York Times 3 July 1996.

Kirisci, Kemal. Turkey's Foreign Policy in Turbulent Times. Paris: European Union Institute for Security Studies, 2006. 
Kirisci, Kemal, and Gareth M. Winrow. The Kurdish Question and Turkey: An Example of a Trans-State Ethnic Conflict. London ; Portland, Or.: Frank Cass, 1997.

Kirişçi, Kemal and Gareth M. Winrow and Ahmet Fethi. Kürt Sorunu: Kökeni Ve Gelişimi. Istanbul: Turkiye Ekonomik ve Toplumsal Tarih Vakfi, 1997.

Kongar, Emre. 21. Yuzyllda Turkiye. Istanbul: Remzi Kitabevi, 1998.

_. Yozlasan Medya Ve Yozlasan Turkiye. Ankara: Remzi Kitabevi, 2003.

Kramer, Heinz. A Changing Turkey: The Challenge to Europe and the United States. Washington, D.C.: Brookings Institution Press, 2000.

Kubálková, V., Nicholas G. Onuf, and Paul Kowert. International Relations in a Constructed World. Armonk, N.Y.: M.E. Sharpe, 1998.

Kuniholm, Bruce. "Turkey's Accession to the European Union: Differences in European and Us Attitudes and Challenges for Turkey." Turkish Studies (Spring 2001): 2553.

Kurop, Marcia Christoff. "Greece and Turkey: Can They Mend Fences?" Foreign Affairs 77, no. 1 (1998): 7-12.

Kushner, David. "Self-Perception and Identity in Contemporary Turkey." Journal of Contemporary History, 32, no. 2 (1997): 219-33.

Laciner, Sedat. Ermeni Sorunu, Diaspora Ve Turk Dis Politikasi: Ermeni Iddialari Turkiye'nin Dunnya Ile Iliskilerini Nasil Etkiliyor? Ankara: Uluslararasi Stratejik Arastirmalar Kurumu, 2008.

_ _ "Turgut Özal Period in Turkish Foreign Policy: Özalism." USAK Yearbook of International Politics and Law 2 (2009): 153-205.

Larrabee, F. Stephen. The Middle East in the Shadow of Afghanistan and Iraq. Santa Monica, CA: RAND, 2003.

—. Turkey as a U.S. Security Partner. Santa Monica, CA: Rand Corp., 2008.

Larrabee, F. Stephen, Ian O. Lesser, and Center for Middle East Public Policy (Rand Corporation). Turkish Foreign Policy in an Age of Uncertainty. Santa Monica, CA: Rand, 2003.

Leiser, Robert Cossaboom and Gary. "Adana Station 1943-45: Prelude to the Post-War American Military Presence in Turkey." Middle Eastern Studies 34, no. 1 (1998): 73-86. 
Lesser, Ian. "Beyond Suspicion: Rethinking Turkey-Us Relations." Washington: Woodrow Wilson International Center for Scholars, 2007.

Lesser, Ian O. Bridge or Barrier: Turkey and the West after the Cold War. Santa Monica, CA: Rand, 1992.

Mango, Andrew. “The Turkish Model.” Middle Eastern Studies 29, no. 4 (1993): 726-57.

Marashlian, Levon. Ermeni Sorunu Ve Türk-Amerikan Ilişkileri: 1919-1923. Translated by Sen Suer: Belge Yayinlari, 2000.

Mardin, Serif. The Center-Periphery Cleavage: A Key to Turkish Politics?, 1972.

—. Turkiye'de Din Ve Siyaset. Istanbul: Iletisim, 1991.

Meho, Lokman I. The Kurdish Question in U.S. Foreign Policy : A Documentary Sourcebook, Documentary Reference Collections. Westport, Conn.: Praeger, 2004.

Mesbahi, Mohiaddin. "Eurasia between Russia, Turkey and Iran." In Key Players and Regional Dynamics in Eurasia, edited by Maria R. Freire and Roger E. Kanet, 164-91. Hampshire: Palgrave Macmillan, 2010.

Minasian, Sergey. "The Turkish-Israeli Military and Political Co-Operation and Regional Security Issues." Iran \& the Caucasus 7, no. 1/2 (2003): 309-26.

Morgenthau, Henry. Ambassador Morgenthau's Story. Garden City, NY: Doubleday, 1918.

Morgenthau, Hans J. Politics among Nations: The Struggle for Power and Peace. 5th ed. New York: Knopf, 1978.

Müftüler-Bac, Meltem. Turkey's Relations with a Changing Europe. New York: Manchester University Press, 1997.

_. "The Never-Ending Story: Turkey and the European Union." Middle Eastern Studies 34, no. 4 (1998).

Mustafa Aydin, Kostas Ifantis, ed. Turkish-Greek Relations: Escaping from the Security Dilemma in the Aegean. London: Routledge, 2004.

Mutlu, Servet. "Economic Bases of Ethnic Separatism in Turkey: An Evaluation of Claims and Counterclaims." Middle Eastern Studies 37, no. 4 (2001): 101-35.

Ofra Bengio, Gencer Ozcan. "Old Grievances, New Fears: Arab Perceptions of Turkey and Its Alignment with Israel." Middle Eastern Studies 37, no. 2 (April 2001): 5092. 
Olson, Robert. "The Kurdish Question in the Aftermath of the Gulf War: Geopolitical and Geostrategic Changes in the Middle East." Third World Quarterly 13, no. 3 (1992): 475-99.

- The Kurdish Nationalist Movement in the 1990s: Its Impact on Turkey and the Middle East. Lexington, KY: University Press of Kentucky, 1996.

Önis, Ziya and Rubin, Barry M. The Turkish Economy in Crisis. London: Frank Cass, 2003.

Onuf, Nicholas. "Constructivism: A User's Manual." In International Relations in a Constructed World, edited by Nicholas Onuf Vendulka Kubalkova, and Paul Kowert. New York: M. E. Sharpe, 1998.

- World of Our Making: Rules and Rule in Social Theory and International Relations. Columbia, S.C.: University of South Carolina Press, 1989.

Oran, Baskın. Kalkık Horoz: Cekic Guc Ve Kurt Devleti. Istanbul: Bilgi Yayınevi, 1996.

—. Turk Dis Politikası. Second ed. Ankara: Iletisim Yayıncılık, 2001.

Ozcan, Gencer. Onbir Aylık Saltanat: Siyaset, Ekonomi Ve Dis Politikada Refahyol Donemi. Istanbul: Boyut Kitapları, 1998.

—. Türkiye-İsrail Ilişkilerinde Dönüşüm: Güvenliğin Ötesi. Istanbul: TESEV Yayinlari, 2005.

Ozcan, Gencer and Sule Kut. En Uzun on Yll: Turkiye'nin Ulusal Guvenlik Ve Dis Politika Gundeminde Doksanlı Yıllar. Istanbul: Boyut Kitapları, 1998.

Özcan, Gencer and Ofra Bengio. "Old Grievances, New Fears: Arab Perceptions of Turkey and Its Alignment with Israel." Middle Eastern Studies 37, no. 2 (2001): 50-92.

Ozdag, Umit. Türk Ordusunun Kuzey Irak Operasyonları: Pegasus Yayinlari, 2008.

Özdal, Habibe and Osman B. Dinçer and Mehmet Yeğin. Mulakatlarla Turk Dis Politikasi. Ankara: USAK, 2009.

Ozkok, Ertugrul. " Ciller'in Abd'den Getirdiği Önemli Istihbarat." Hurriyet March 11, 2002.

__. "Zirvede Yeni Bir Karar Mi Alınd1." Hurriyet September 6, 1999.

"Para Icin Degmez ". Milliyet October 7, 1996. 
Parris, Mark. "Ambassador-Designate Mark Parris Statement at Confirmation Hearing." edited by Senate Foreign Relations Committee. Washington, DC, September 23, 1997.

Prager, Rachel. "Turkish-American Relations: Historical Context and Current Issues." Turkish Industrialists' and Businessmen's Association, 2003.

Pulur, Hasan. "Eger Ceza Yasasi Degistirilebilseydi." Milliyet July 1, 1999.

Qadir, Charles Recknagel and Sa'ad Abdul. "Iraq: Washington Seeks to Strengthen Kurdish Accord ": Radio Free Europe Radio Liberty RFE/RL, January 09, 1999.

"Remarks by the President in Address to the Turkish Grand National Assembly." edited by The White House. Washington, DC, November 15, 1999.

Robert D. Blackwill, Michael Stürmer. Allies Divided: Transatlantic Policies for the Greater Middle East. Cambridge, MA: MIT Press, 1997.

Robins, Philip. "Confusion at Home, Confusion Abroad: Turkey between Copenhagen and Iraq." International Affairs (Royal Institute of International Affairs 1944-) 79, no. 3 (May 2003): 547-66.

_ Affairs 69, no. 4 (1993): 657-76.

- Suits and Uniforms: Turkish Foreign Policy since the Cold War. Seattle, Wash.: University of Washington Press, 2003.

_. Turkey and the Middle East. London: Pinter Publishers, 1991.

_ . "Turkish Foreign Policy since 2002: Between a 'Post-Islamist' Government and a Kemalist State " International Affairs 83, no. 1 (2007): 289-304.

Rose, Gideon. "Neoclassical Realism and Theories of Foreign Policy." World Politics 51, no. 1 (1998).

Rubin, Barry M., and Metin Heper. Political Parties in Turkey. London ; Portland, OR: Frank Cass, 2002.

Rubin, Michael. "A Comedy of Errors: American-Turkish Diplomacy and the Iraq War " Turkish Policy Quarterly (Spring 2005): 69-80.

Safi, Ismail. Türkiye'de Muhafazakâr Siyaset Ve Yeni Arayışlar: Lotus, 2007.

Sander, Oral. Turk-Amerikan Iliskileri 1947-1964 Ankara: Ankara Universitesi Sosyal Bilimler Fakultesi Yayinlari, 1979. 
Sariibrahimoglu, Lale. "Us Lays Ground Work to Knock on Saddam's Door Via Turkey." Turkish Daily News December 12, 2001.

Satterthwaite, Joseph C. "The Truman Doctrine: Turkey." Annals of the American Academy of Political and Social Science 401 (1972): 74-84.

Sayari, Sabri. "The United States and Turkey's Membership in the European Union." In The Turkish Yearbook, 167-76: 34, 2003.

Sayari, Sabri, and Yilmaz R. Esmer. Politics, Parties, and Elections in Turkey. Boulder, CO: Lynne Rienner Pub., 2002.

Saylan, Gencay. Turkiye'de Islamcl Siyaset. Ankara: Verso, 1992.

Sedat Laçiner, Mehmet Özcan, İhsan Bal. European Union with Turkey: The Possible Impact of Turkey's Membership on the European Union. Ankara: Usak, 2005.

Selcuk, Ilhan. "Dincilerin Azgınlığı." Cumhuriyet October 10, 2006.

Sever, Ayşegül. "The Compliant Ally? Turkey and the West in the Middle East 1954-58." Middle Eastern Studies 34, no. 2 (1998): 73-90.

Sever, Metin. Kürt Sorunu: Aydınlarımız Ne Düşünüyor. Ankara: Cem Yayinevi, 1992.

Sezal, Ihsan and Ihsan Dagi. Kim Bu Özal?: Siyaset, Iktisat, Zihniyet. Ankara: Boyut Kitaplari, 2001.

Sezer, Ayten. "Osmanli'dan Cumhuriyete: Misyonerlerin Turkiye'deki Egitim Ve Ogretim Faaliyetleri " Hacettepe Universitesi Edebiyat Fakultesi Dergisi Special Edition (1999).

Sezer, Necdet. "I Reckon Western Countries Are Going to View Terrorism Differently from Now On." Turkish Daily News 13 September 2001.

Silleli, Turan. Türkiye-Irak Ilişskileri: IQ Kultur ve Sanat Yayincilik, 2005.

Sönmezoğlu, Faruk. Türk Dış Politikasının Analizi Istanbul: Der Yayinlari, 2004.

Soylemez, Hasim. "Esref Bitlis ile Cem Ersever'i Ayni Ekip Oldurdu (Esref Bitlis and Cem Ersever were both Killed by the Same Team)." Aksiyon 11 August 2008.

Soylemez, Yuksel. "My Terrorist May Be Your Friend." Turkish Daily News 13 September 2001.

Soysal, Ismail. Türk Dis Politikası Incelemeleri Için Kılavuz, 1919-1993. Ankara: Eren Yayincilik, 1993. 
Sübidey Togan, Bernard M. Hoekman. Turkey: Economic Reform and Accession to the European Union. Washington, DC: World Bank, 2005.

Sukru Elekdag. "Abd, Turkiye'yi Neden Destekliyor." Milliyet April 30, 1995.

"Suleyman Demirel Ve Abd Başkanı Bill Clinton'ın Çankaya Köşkü'ndeki Konusmalari ". edited by TC Disisleri Bakanligi. Ankara, November 15, 1999.

Talbott, Strobe. "U.S.-Turkish Relations in an Age of Interdependence." In Turgut Ozal Memorial Lecture. Washington, DC: Washington Institute on Near East Policy, October 14, 1998

"Tam Bir Fiyasko." Milliyet October 7, 1996.

Tamar Gabelnick, William D. Hartung, and Jennifer Washburn. "Arming Repression: Us Arms Sales to Turkey During the Clinton Administration." the World Policy Institute and the Federation of American Scientists October 1999.

Taspinar, Omer. Kurdish Nationalism and Political Islam in Turkey: Kemalist Identity in Transition. New York: Routledge, 2005.

Tayyar, Samil. "28 Şubat Talimatı Abd'den (February 28th Order Was from the United States)." Star December 15, 2010.

Tekin, Uzeyir. Ak Parti'nin Muhafazakâr Demokrat Kimliği: Orient, 2004.

"Terörün Ekonomik Maliyeti: Diyarbakır Olayları Örneği." Ankara: USAK, 2010.

"The National Security Strategy of the United States of America." edited by The White House. Washington, DC, September 2002.

Timur, Taner. Turk Devrimi ve Sonrasl. Ankara: Imge Yayinlari, 1993.

Tinc, Ferai. "Şer Ekseni Türkiye Için Ne Anlama Geliyor? ." Hurriyet February 4, 2002.

—_. "Türkiye'nin Kuzey Irak Politikası Nedir?" Hurriyet October 2, 1998.

Tokatli, Orhan. Kırmızı Plakalar: Türkiye'nin Özal'lı Yılları. Istanbul: Dogan Kitap, 1999.

Toprak, Binnaz. Islam and Political Development in Turkey. Leiden: Brill, 1981.

Torumtay, Necip. Orgeneral Torumtay'in Anilari. Istanbul: Milliyet Yayinlari, 1993.

"Transcript of President Bush's First State of the Union Address." CNN, http://edition.cnn.com/2002/ALLPOLITICS/01/29/bush.speech.txt/.

Tunaya, Tarik Z. Turkiye'de Siyasi Partiler. Vol. 3. Ankara: Iletisim Yayınc1lk, 1999. 
Turel, Oktar. Akdeniz'de Bir Ada: KKTC'nin Varolus Oykusu. Ankara: Imge Yayınları, 2002.

"Turkey-Israel-U.S. Trialogue." edited by BESA Center for Strategic Studies, 10 December 2002.

"Turkey's New Kurdish Policy." Milliyet December 10, 1991.

"Turkey's Quest for EU Membership." In EU Briefings: European Union Center of North Carolina, 2000.

Ucarol, Rifat. Siyasi Tarih. Istanbul: Filiz Kitapevi, 2000.

"Uluslararası Muhafazakarlık Ve Demokrasi Sempozyumu." Istanbul: Ak Parti, January 2004.

Uslu, Nasuh. The Cyprus Question as an Issue of Turkish Foreign Policy and TurkishAmerican Relations, 1959-2003. Hauppauge, N.Y.: Nova Science Publishers, 2003.

—. Türk - Amerikan Ilişkilerinde Kıbrıs. Ankara: 21. Yuzyil Yayinlari, 2000.

—. Turk Dis Politikası Yol Ayrımında: Soğuk Savaş Sonrasında Yeni Sorunlar, Yeni Imkânlar Ve Yeni Arayışlar. Ankara: Anka, 2006.

- The Turkish-American Relationship between 1947 and 2003 : The History of a Distinctive Alliance. Hauppauge, N.Y.: Nova Science Publishers, 2003.

Uysal, Cemal. DP'den AKP'ye Özgürlük Ve Zenginlik Mücadelesi: Demokrasi, Politika Ve Ekonomi Üzerine Görüşler: Yargi Yayinevi, 2008.

Váli, Ferenc Albert. Bridge across the Bosporus; the Foreign Policy of Turkey. Baltimore,: Johns Hopkins Press, 1971.

Vojtech Mastny, R. Craig Nation. Turkey between East and West: New Challenges for a Rising Regional Power. Boulder, CO: Westview, 1996.

Waltz, Kenneth. "Realist Thought and Neorealist Theory." Journal of International Affairs 44, no. 1 (1990): 21-37.

—. Realism and International Politics. New York: Routledge, 2008.

—. Theory of International Politics. Reading, MA: Addison-Wesley, 1979.

Weiner, Tim. "U.S. Helped Turkey Find and Capture Kurd Rebel." New York Times February 20, 1999. 
Wendt, Alexander. Social Theory of International Politics. New York, NY: Cambridge University Press, 1999.

— . "Anarchy Is What States Make of It: The Social Construction of Power Politics." International Organization 46, no. 2 (1992): 391-425.

Wittes, Tamara Cofman. "The New U.S. Proposal for a Greater Middle East Initiative: An Evaluation." Brookings, May 10, 2004.

Yalcin, Soner and Mehmet A. Birand. The Özal: Bir Davanın Öyküsü. Istanbul: Dogan Kitap, 2001.

Yavuz, Hakan. Modernlesen Muslumanlar: Nurcular, Naksiler, Milli Gorus Ve Ak Parti. Istanbul: Kitap Yayinevi, 2005.

- Secularism and Muslim Democracy in Turkey: Cambridge University Press, 2009.

- The Emergence of a New Turkey: Democracy and the AK Parti. Salt Lake City, UT: University of Utah Press, 2006.

- Islamic Political Identity in Turkey, Religion and Global Politics. New York: Oxford University Press, 2003.

_. "Turkish-Israeli Relations through the Lens of the Turkish Identity Debate." Journal of Palestine Studies 27, no. 1 (1997): 22-37.

Yavuz, Turan. ABD'nin Kürt Kartı. Istanbul: Milliyet Yayinlari, 1993.

Yavuzalp, Ercument. Liderlerimiz Ve Dis Politika: Bir Diplomat Gözüyle. Ankara: Bilgi Yayinevi, 1996.

Yeldan, Erinc. Kuresellesme Surecinde Turkiye Ekonomisi: Bolusum, Birikim Ve Buyume. Istanbul: Iletisim Yayıları, 2001.

Yenal, Oktay. Cumhuriyet'in Iktisat Tarihi. Istanbul: Homer Kitabevi, 2003.

Yenigun, Cuneyt. Soğuk Savaş Sonrasında Tbmm Ve Dış Politika: Belgeler-Yorumlar. Ankara: Nobel, 2004.

Yetkin, Murat. Tezkere: Irak Krizinin Gerçek Öyküsü. 2 ed. Ankara: Remzi Kitabevi, 2004.

Yucel, Serhan. Türkiye'nin Siyasal Partileri: 1859-2006: Alfa Yayinlari, 2005.

Zurcher, Eric J. Imparatorluktan Cumhuriyete Türkiye'de Etnik Çatışma. Istanbul: Iletisim, 2005. 
. The European Union, Turkey and Islam. Amsterdam: Amsterdam University Press, 2004. 
VITA

ISA AFACAN

1975

1999

2001

2001-2004

2004-2006

2006-2008

$2008-2011$

Born, Konya, Turkey

B.A., Political Science and Public Administration Bilkent University

Ankara, Turkey

M.A., International Relations

Fatih University

Istanbul, Turkey

Teaching Assistant

Department of International Relations

Florida International University

Miami, Florida

Adjunct Instructor

Department of International Relations

Florida International University

Miami, Florida

Social Studies Teacher

TEACH

Alpharetta, Georgia

Director of Academic Affairs

Istanbul Center

Atlanta, Georgia

PhD Candidate

Department of International Relations

Florida International University

Miami, Florida

\section{PUBLICATIONS AND PRESENTATIONS}

Afacan, Isa, (September 24, 2010). Civil-Military Relations and Democratization in Turkey and its Impact on the United States. Paper presented at Vanderbilt University, Nashville, TN. 
Afacan, Isa, (September 3, 2009). Turkish-American Relations in Disarray: Iraqi War of 2003 and Beyond. Paper presented at the Middle East Institute, Georgia State University, Atlanta, GA. 